TAY

CER 78-79/70

copy 2 -

Flood of 31 July 1976 in Big

Thompson

Canyon,

Colorado

Enginouriod Scliences

Nationa

Research

Council

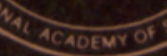

ocina yed

Branch Liandy 


\title{
FLOOD OF 37 JULY 1976 \\ IN \\ BIG THOMPSON CANYON, COLORADO
}

by

D. B. Simons, J. D. Nelson, E. R. Reiter, and R. L. Barkau

Colorado State University

Fort Collins, Colorado

\author{
submitted to the \\ Committee on Natural Disasters \\ Commission on Sociotechnical Systems \\ NATIONAL RESEARCH COUNCIL
}

\author{
National Academy of Sciences \\ Washington, D.C. \\ 1978
}


NOTICE

The project that is the subject of this report was approved by the Governing Board of the National Research Council, whose members are drawn from the Councils of the National Academy of Sciences, the National Academy of Engineering, and the Institute of Medicine. The members of the Committee responsible for the report were chosen for their special competences and with regard for appropriate balance.

This report has been reviewed by a group other than the authors according to the procedures approved by a Report Review Committee consisting of members of the National Acaderny of Sciences, the National Academy of Engineering, and the Institute of Medicine.

Financial support for publication of this report was provided by the National Science Foundation.

The National Research Council was established in 1916 by the National Academy of Sciences to associate the broad community of science and technology with the Academy's purposes of furthering knowledge and of advising the federal government. The Council operates in accordance with general policies determined by the Academy by authority of its Congressional charter of 1863 , which established the Academy as a private, non-profit, self-governing membership corporation. Administered jointly by the National Academy of Sciences, the National Academy of Engineering, and the Institute of Medicine (a11 three of which operate under the charter of the National Academy of Sciences), the Council is their principal agency for the conduct of their services to the government, the public, and the scientific and engineering communities.

Copies of this report may be obtained from the office of the Committee on Natural Disasters, National Academy of Sciences, 2101 Constitution Avenue, Washington, D.C. 20418 
FOREWORD

The Committee on Natural Disasters of the National Research Council has as a part of its responsibility the investigation of engineering features of natural disasters. Reports of the findings of investigating teams are published by the National Academy of Sciences to provide engineers with information required to improve the level of protection against natural hazards and to stimulate the research needed to understand the threat posed by these hazards.

This report is the result of a study of the flood that occurred on the Big Thompson River near Loveland and Estes Park, Colorado, on the evening of Saturday, July 31, 1976. The flood was an exceptional hydrological event and the damage and loss of life in the canyon were heavy. The report, compiled by a team of engineers and scientists from Colorado State University, describes the mechanics of the flooding and the engineering aspects of the damages.

P. C. Jennings, Chairman

Committee on Natural Disasters 


\section{ACKNOWLEDGMENTS}

The authors wish to thank all the people who assisted in the preparation of this report, especially Bruce C. McDonald, a Graduate Research Assistant who helped analyze the meteorological data;

Thomas V. Edgar, a Graduate Research Assistant who helped prepare the geotechnical section of this report; Jerald McCain of the U.S. Geological Survey, who supplied the flood discharge information; and the staff of Colorado State University, who prepared figures and typed the report.

D. B. Simons, Associate Dean

College of Engineering

J. D. Nelson, Associate Professor

Civil Engineering

E. R. Reiter, Professor

Atmospheric Science

R. L. Barkau

Graduate research Assistant

Colorado State University

Fort Collins, Colorado 
IMPACT OF THE FLOOD

Floodplain Zoning

Other Canyons along the Front Range

BIBLIOGRAPHY 


\section{LIST OF TABLES}

1. Causes of Extreme Flood Discharges in the Big Thompson 5 Basin (Kleher et a1., 1976)

2. Summary of Flood Discharges in the Big Thompson River Flood (McCain, 1977)

3. Flow Frequency Data at Selected Discharge Sites in the Big Thompson Canyon

4. Summary of Direct Economic Losses in the Big Thompson Flood (U.S. Corps of Engineers, 1976)

5. Major Floods along the Colorado Front Range (Follansbee, 1947) 
1. Big Thompson Drainage Basin 3

2. Topography of the Big Thompson Canyon 4

3. Rainfal1 Amounts during 31 July 1976 Storm 7

4. Accumulated Rainfall vs. Time for Glen Comfort and 8 Glen Haven, 31 July 1976 (Maddox 1977)

5. Surface Weather Maps for the Central United States, 1800 and 2100 GMT, 31 July 1976 and 0000 GMT, 1 August 1976

6. Vertical Cross-Section of Potential Temperature Distribution 10 $\left({ }^{\circ} \mathrm{K}\right), 0000$ GMT, 1 August 1976

7. Vertical Sounding of the Atmosphere Plotted in Thermodynamic 11 Diagrams for 0000 GMT, 1 August 1976

8. Dirks (1970) Model of the Evolution of the Stream Function, 14 and Potential Temperature Deviation for a Deep Adiabatic Layer in the Lower Troposphere with Essentially Calm Conditions in the Troposphere at Initial Time

9. Synoptic Reports and Analyses of Upper Level Pressure Surfaces over the Western U.S. at 0000 GMT on 1 August 1976

10. A Series of Radar Echo Configurations Derived from the 17 Limon Radar Data for 31 July 1976 and 1 August 1976

11. Discharge Sites on the Big Thompson River above Drake for 22 the 31 July 1976 Flood

12. Discharge Sites on the North Fork Big Thompson River for the 23 31 July 1976 Flood

13. Discharge Sites on the Big Thompson River below Drake for the 24 31 July 1976 Flood

14. Boulder Deposit Upstream of Drake 28

15. Sheet Erosion along Dry Gulch near Estes Park 29

16. Erosion along Outside and Deposition along Inside of Stream Bed 30

17. Sediment Transport along the Big Thompson River above Drake 31 on 31 July 1976

18. Sediment Transport along the North Fork Big Thompson River 32 above Drake on 31 July 1976

19. Sediment Transport along the Big Thompson River below Drake 33 on 31 July 1976

20. Sediment Transport vs. Stream-Bed Slope and Valley Width along the Big Thompson River 
21. Sediment Transport vs. Stream-Bed Slope and Valley Width along the North Fork Big Thompson River

22. Small Tributaries Entering the Big Thompson River near Glen Comfort, before and after the Flood

23. Severe Scour along the Big Thompson River above Waltonia

24. Waltonia Area before and after the Flood 39

25. Scour on the Reach Upstream from Drake 40

26. Sediment Deposited in the Glen Haven Area 40

27. Scour along the North Fork 41

28. Deposits along the North Fork near the Fish Hatchery 42 just Upstream from Drake

29. Grading of Materials Deposited by the Big Thompson River 43 at Drake

30. Drake before and after the Flood 44

31. Deposits from the North Fork at Drake 45

32. Deposits near Cedar Grove 47

33. Scour in the Narrows Area near the Bureau of Reclamation 48 Diversion Structure

34. Deposits below the Mouth of the Canyon 48

35. Overbank Deposits in the Plains Area 49

36. Erosion of Outside Bend of U.S. Highway $34 \quad 50$

37. Erosion of Road between Bridge and Dam at Loveland 51 Filtration Plant

38. Scour in Drainage Ditch on inside of U.S. Highway 34

39. Extensive Gullying in Dunraven Glade Area 52

40. Erosion of Backfill Material at Bridge Abutment 53

41. Abutments of Destroyed Bridge near Loveland Filtration Plant 53

42. Close-up View of Right Abutment Shown in Figure 41 
43. Repaired Highway Embankment Washed out by Subsequent Storm

44. Repaired Pavement Eroded by Scour in Drainage Ditch 55

45. Repaired Highway Embankment Eroded by Water from Tributary 56

46. Storm Waters Wasing over Culvert 56

47. Town of Drake after the Flood 58

48. Loveland Power Plant 59

49. Failure of Timber Foundation with Stone Masonry Facing 60

50. Failure of Concrete Block Foundation 60

51. Erosion of Foundation Bearing Material 61

52. Erosion of Debris Fan below Foundation 61

53. Remedial Measures Being Taken for Foundation Repair 62

54. Erosion below Slab on Grade Foundation 62

55. Root Zone of Soil Cover 64

56. Rock Fall along Highway 65

57. Landslide in Residual Soil 65

58. Slope in Colluvium along North Fork 66

59. Slope Failure in Colluvium along Big Thompson River 67 Approximately 3 to 4 Miles West of Drake

60. Slope Failure at Drake 69

61. Slope Failure Formed about One Week after the Flood 70

62. Erosion along Dry Gulch 71

63. Erosing of Debris Fan 71

64. Remains of Loveland Hydroelectric Dam 73

65. O1ympus Dam 73

66. House Damaged by Tree Hurled through Upstream Wa11 75

67. House near Drake Flattened by Boulders and Debris 76 
68. Sediment Deposited around House along West Creek

69. Remains of Loveland Power Plant at Loveland Mountain Park

70. Siphon Support Structure and Feeder Canal Located at the Mouth of the Canyon

71. Remains of the U.S. Bureau of Reclamation Siphon 


\section{INTRODUCTION}

On Saturday, July 31, 1976, the eve of Colorado's Centennial Celebration, almost 4,000 people were enjoying the serene beauty of the Big Thompson Canyon, unsuspecting of coming tragedy. During the evening an intense thunderstorm stalled over a small portion of the canyon, dropping 10 or more inches of rain in a 3-hour period. Because of the steep mountain topography, the rainfall quickly concentrated and formed a virtual "wall of water" which displaced everything in its path. Houses, trees, sediment, and boulders were swept downstream. The toll was staggering: 139 people dead, 4 missing, and property damage exceeding $\$ 41,000,000$.

The Big Thompson flood struck an area that was totally unprepared for such an event. Previous floods that had swept through the canyon were of a much smaller magnitude and had caused much less damage. The previous maximum observed flood, which occurred in 1915, had a peak discharge of $8,000 \mathrm{cfs}$ at the mouth of the canyon -- much less than the $31,200 \mathrm{cfs}$ observed during the 1976 flood. Also, no significant flooding had occurred in the canyon in the 20 years prior to the $1976 \mathrm{flood}$. As a result, flood dangers were ignored and, through the years, residential and commercial development had encroached on the floodplain area. During the flood, most of the death and damage was in this developed area of the floodplain.

The Big Thompson flood has provided a grim reminder of the flash flood hazards in mountain canyons. In the Big Thompson, the Larimer County Planning Commission has adopted zoning ordinances to restrict the redevelopment of flood hazard areas. Unfortunately, this foresight has not extended to other canyons that have equal or greater developments and are equally vulnerable to disaster.

It is the purpose of this report to describe the Big Thompson flood and its impact on the front range. The report will discuss the meteorologic conditions that caused the flood, the resulting flood discahrges, the geomorphic and geotechnical processes associated with the flood, the economic losses, and finally, the impact of the flood on the canyon and the front range. The writers hope this report will inform people of the flash flood hazards in mountain canyons and the awesome processes unleashed when these events occur.

\section{DESCRIPTION OF BIG THOMPSON BASIN}

The Big Thompson River is a western tributary of the South Platte River that drains an area of the Rocky Mountains and the plains in north 
central Colorado. Figure 1 shows the location of the Big Thompson basin. From its origin in the Rocky Mountain National Park, the river flows eastward through Estes Park and the Big Thompson Canyon out onto the plains. From there, the river continues eastward through Loveland, Colorado, to its confluence with the South Platte near LaSalle, Colorado. Its major tributaries are the North Fork Big Thompson River, Cedar Creek, Buckhorn Creek, and the Little Thompson River.

The topography of the Big Thompson basin is varied. The western section, beginning at the Continental Divide and ending at the mouth of the canyon, drains a portion of the front range. Elevations range from $5,360 \mathrm{ft} \mathrm{ms} 1 *$ at the mouth of the canyon to over $14,000 \mathrm{ft} \mathrm{ms} 1$ near the Continental Divide. The eastern section, which begins at the mouth of the canyon and extends eastward, drains an area of gently rolling plains. Stream gradients range from $113 \mathrm{ft} / \mathrm{mile}$ within the canyon to $26 \mathrm{ft} / \mathrm{mile}$ along the plains.

Since the early $1950^{\prime} \mathrm{s}$, flow from the Big Thompson River has been modified by the Colorado Big Thompson Project. The Bureau of Relamation project diverts water from the western slope, across the Continental Divide, and then to Lake Estes near Estes Park. From there the water is diverted through the Olympus tunnel out onto the eastern plains. Olympus Dam, which forms liake Estes, effectively controls low flow on the Big Thompson River and, to a limited extent, controls floodwaters from upstream. Excess floodwaters are stored for release at a later time, or for diversion through the 0lympus tunnel. During the July 31 flood, the gates of Olympus Dam were closed at $2055 \mathrm{MDT}$ and excess floodwaters were stored and diverted.

\section{Big Thompson Canyon}

The Big Thompson Canyon extends from Olympus Dam to the mouth of the Canyon about 7 miles west of Loveland. Two major tributaries have their confluences with the Big Thompson within the Canyon: North Fork at Drake and Cedar Creek near Cedar Grove. The canyon, bordered by steep, treecovered slopes, forms a beautiful mountain valley that yearly attracts thousands of visitors. A main thoroughfare to Rocky Mountain National Park, U.S. Highway 34, runs through the Canyon and increases the number of visitors to the Canyon.

The canyon topography is very rugged and mountainous (Figure 2). The narrow valley is surrounded by steep side slopes with gradients of 10 to 80 percent. At several locations rugged rock faces rise above the canyon floor for several thousand feet. Some mountain tops in the canyon area exceed $9,500 \mathrm{ft} \mathrm{msl}$. Stream-bed elevations vary from 5,320 ft msl at the canyon's mouth to $7,420 \mathrm{ft}$ msl at Olympus Dam.

The Big Thompson Canyon is deeply incised into Precambrian metamorphic schist and gneiss. Numerous igneous dikes complicate the geology of the area. On gentle to moderate slopes ( 5 to $15 \%$ ), the weathering of bedrock has formed a thin gruss mantle. Steeper slopes are strewn with boulder rubble. Valleys are covered by alluvium and slope wash materials. Colluvium can be found along all but the steepest slopes. In some cases

*msl - mean sea level 


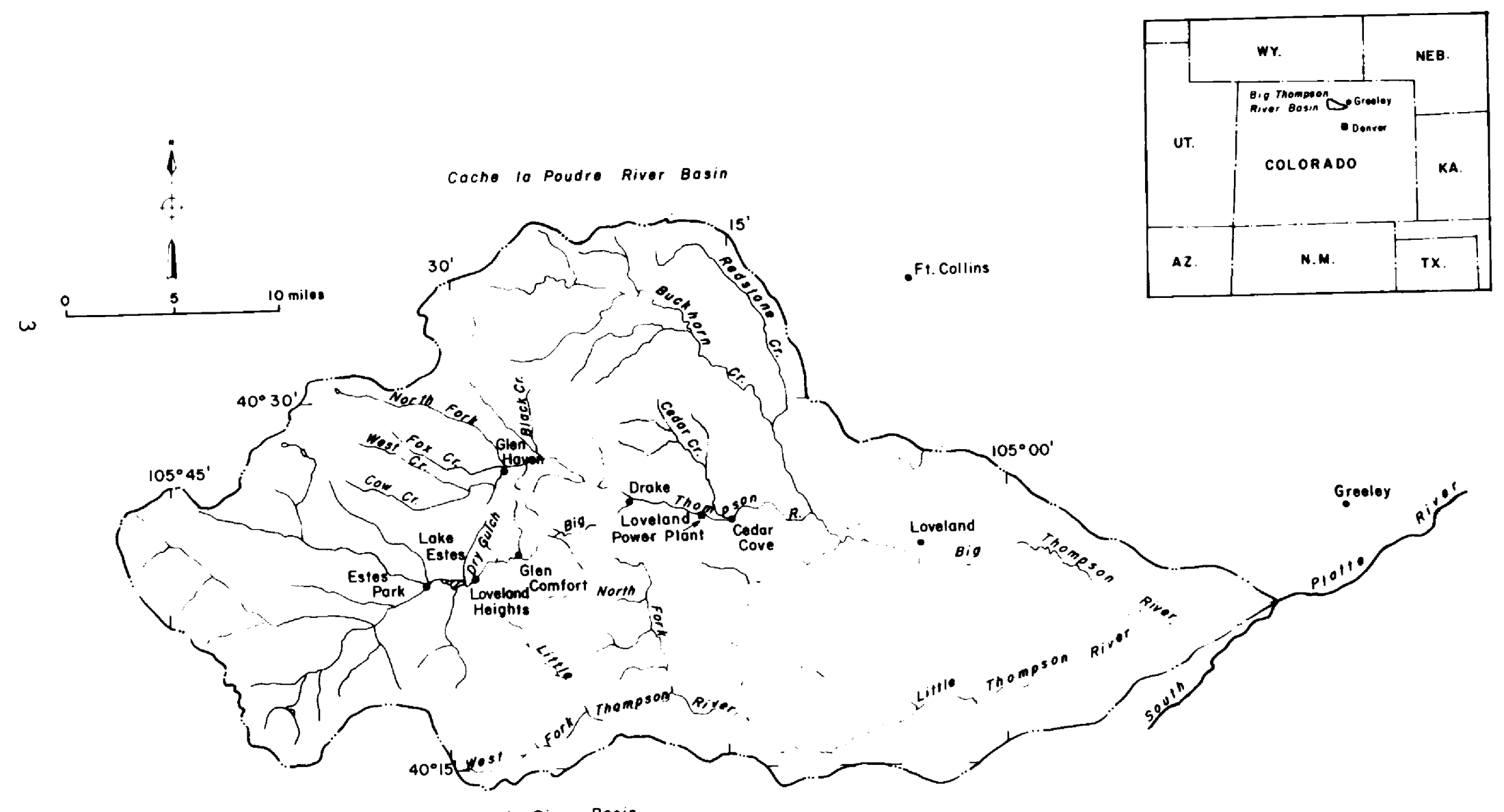

St. Vrain River Bosin

FIGURE 1 Big Thompson Drainage Basin 


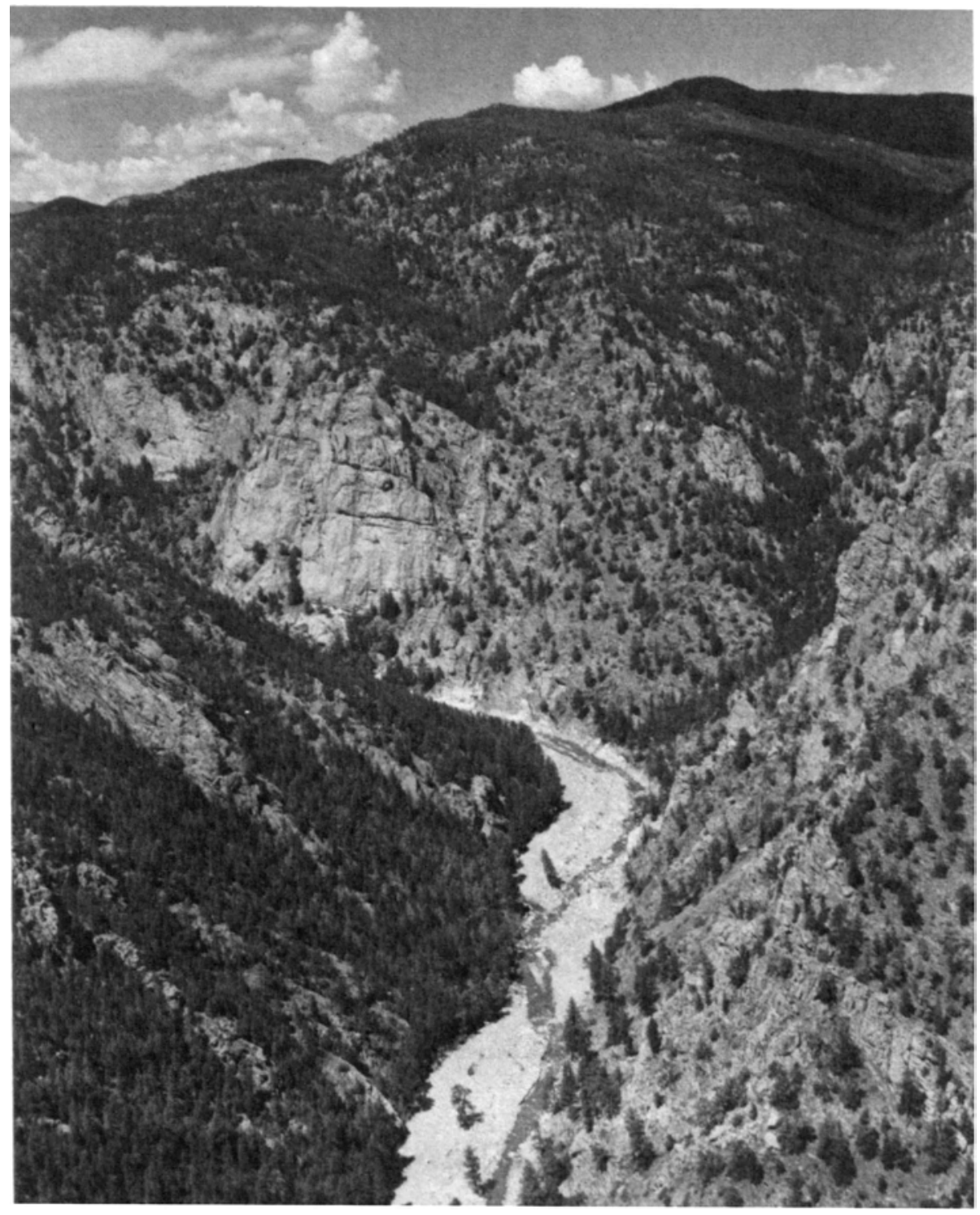

FIGURE 2 Topography of the Big Thompson Canyon

where the valley widens (Drake and Cedar Grove areas), large alluvial deposits have developed. In general, soils are rather thin, and grade from stoney near the tops of ridges, to sandy along more moderate slopes and the valley floor. All soils are highly susceptible to severe erosion.

Floods in the Big Thompson Basin

Floods along the front range streams usually come from three sources: snowmelt, cloudburst, and cloudburst over snowmelt. Snowmelt floods which occur in the spring of the year are characterized by a slow rise and fall in flood levels. 
A cloudburst is an intense thunderstorm which drops a 1arge amount of rain over a small area in a few minutes. Cloudbursts which occur between May and September are caused by the orographic lifting of conditionally unstable air by the mountain topography. They usually produce flash floods with large peak flows that rise and fall rapidiy.

The most potentially severe flood event is caused by a cloudburst over snowpack. Because of the run-off from snowmelt, streams are a1ready at high levels when the cloudburst occurs. The heavy rains quickly run off the snow-covered terrain (which has little infiltration capacity), hastening snowmelt. The resulting flash flood brings an already swollen stream to higher stages.

Table 1 lists the peak flows over $3,000 \mathrm{cfs}$ and their causes.

TABLE 1

Causes of Extreme Flood Discharges in the Big Thompson Basin (K1eher et a1., 1976)

\begin{tabular}{|c|c|c|c|c|c|}
\hline & Date & & $\begin{array}{c}\text { Flood } \\
\text { Discharge }\end{array}$ & Cause & Comment \\
\hline 31 & July & 1919 & $8,000 \mathrm{cfs}$ & Cloudburst & $\begin{array}{l}\text { Storm centered a short } \\
\text { distance above Drake }\end{array}$ \\
\hline $2-7$ & June & 1921 & $3,000 \mathrm{cfs}$ & $\begin{array}{l}\text { Cloudburst } \\
\text { over snowpack }\end{array}$ & $\begin{array}{l}17 \text { days of flow above } \\
1,000 \text { cfs after June } 4\end{array}$ \\
\hline 9 & June & 1923 & $7,000 \mathrm{cfs}$ & $\begin{array}{l}\text { Cloudburst } \\
\text { over snowpack }\end{array}$ & $\begin{array}{l}21 \text { days of flow above } \\
1,000 \mathrm{cfs}\end{array}$ \\
\hline 15 & June & 1924 & $2,950 \mathrm{cfs}$ & Snowme1t & $\begin{array}{l}\text { Entire month of June greater } \\
\text { than } 1,000 \mathrm{cfs} \text { daily mean flo }\end{array}$ \\
\hline 1 & Sept & 1938 & $5,060 \mathrm{cfs}$ & Cloudburst & \\
\hline 22 & June & 1941 & $4,700 \mathrm{cfs}$ & Cloudburst & \\
\hline 7 & June & 1942 & 3,750 cfs & Snowmelt & $\begin{array}{l}16 \text { days in June with flow } \\
\text { greater than } 1,000 \mathrm{cfs}\end{array}$ \\
\hline 20 & July & 1945 & $7,600 \mathrm{cfs}$ & Cloudburst & \\
\hline 4 & June & 1949 & $3,350 \mathrm{cfs}$ & $\begin{array}{l}\text { Cloudburst } \\
\text { over snowpack }\end{array}$ & $\begin{array}{l}24 \text { days of flow greater } \\
\text { than } 1,000 \mathrm{cfs}\end{array}$ \\
\hline 3 & Aug & 1951 & $3,550 \mathrm{cfs}$ & Cloudburst & Heavy rain on Aug 2 and 3 \\
\hline 31 & July & 1976 & $31,200 \mathrm{cfs}$ & Cloudburst & Storm centered above Drake \\
\hline
\end{tabular}




\section{METEOROLOGICAL CONDITIONS LEADING TO THE BIG THOMPSON FLOOD}

The rainy season along the eastern slopes of the Rocky Mountains of Colorado falls into the time period from May to August, when convective precipitation systems form along the Continental Divide, often in conjunction with a quasi-stationary frontal system. Influx of moist air at low levels in the troposphere from the Gulf of Mexico and onset of convection along the mountain ranges supported by the slope of the terrain are the primary factors governing the precipitation processes during this season. The sequence of events leading to the Big Thompson flood of 31 July and 1 August was no exception to the usual rainy-season weather pattern. The excessive amounts of precipitation which fell on these two days in the entrainment area of the Big Thompson River, mainly in the vicinity of Glen Comfort and Glen Haven (Figure 3), have been ascribed to an unfortunate superposition of mesoscale terrain and weather parameters rather than the unusual large-scale weather patterns. From Figure 4 it can be seen that most of the precipitation at Glen Comfort fell between 2000 and 2100 MDT giving rise to flash-flood conditions.

The surface weather maps, prior to the onset of the Big Thompson flood, show all the necessary ingredients of the Colorado thunderstorm season: a weak cold front had become stationary over Missouri and Kansas, with its trailing end lying against the mountains of southern Colorado. In Figure 5 the surface weather maps for 1800 GMT and 2100

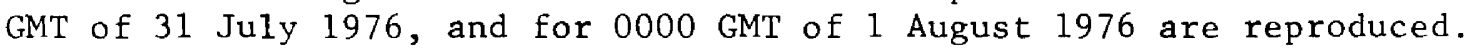
(Local daylight-saving time precedes Greenwich Mean Time by 6 hours. Thus 0000 GMT of 1 August marks the onset of the flood conditions at 6 p.m. of 31 July 1976.) In these maps we have indicated the dew-point temperature distribution in the vicinity of the stationary front. The dew-point temperature provides an indication of the moisture content of the air. Where the dew point equals the actual temperature, the air is saturated with moisture (Relative Humidity $=100 \%$ ). The larger the difference between the actual temperature and the dew-point temperature, the dryer is the air.

A tongue of moist air with dew points above $65^{\circ} \mathrm{F}$ extends behind the cold front that separates the modified air to the north from the tropical air to the south. A flow component from the east is pushing this moist air against the mountains. Convective precipitation systems that break through the frontal inversion capping the shallow polar-air outbreak tap the moisture in the tropical air aloft and bring it to the ground in heavy thundershowers. Re-evaporation of this precipitation leads to a moistening of the low-tropospheric polar-air mass and to an enforcement of the thunderstorm activity in association with the weak frontal system shown in Figure 5.

Their is some question as to how far westward the tongue of moist air extended on $31 \mathrm{July}$. The maps shown in Figure 5 depict the $70^{\circ} \mathrm{F}$ dew-point temperature isotherm stopping short of the Colorado state line. Maddox et al. (1977) claim that the excessively moist air actually 


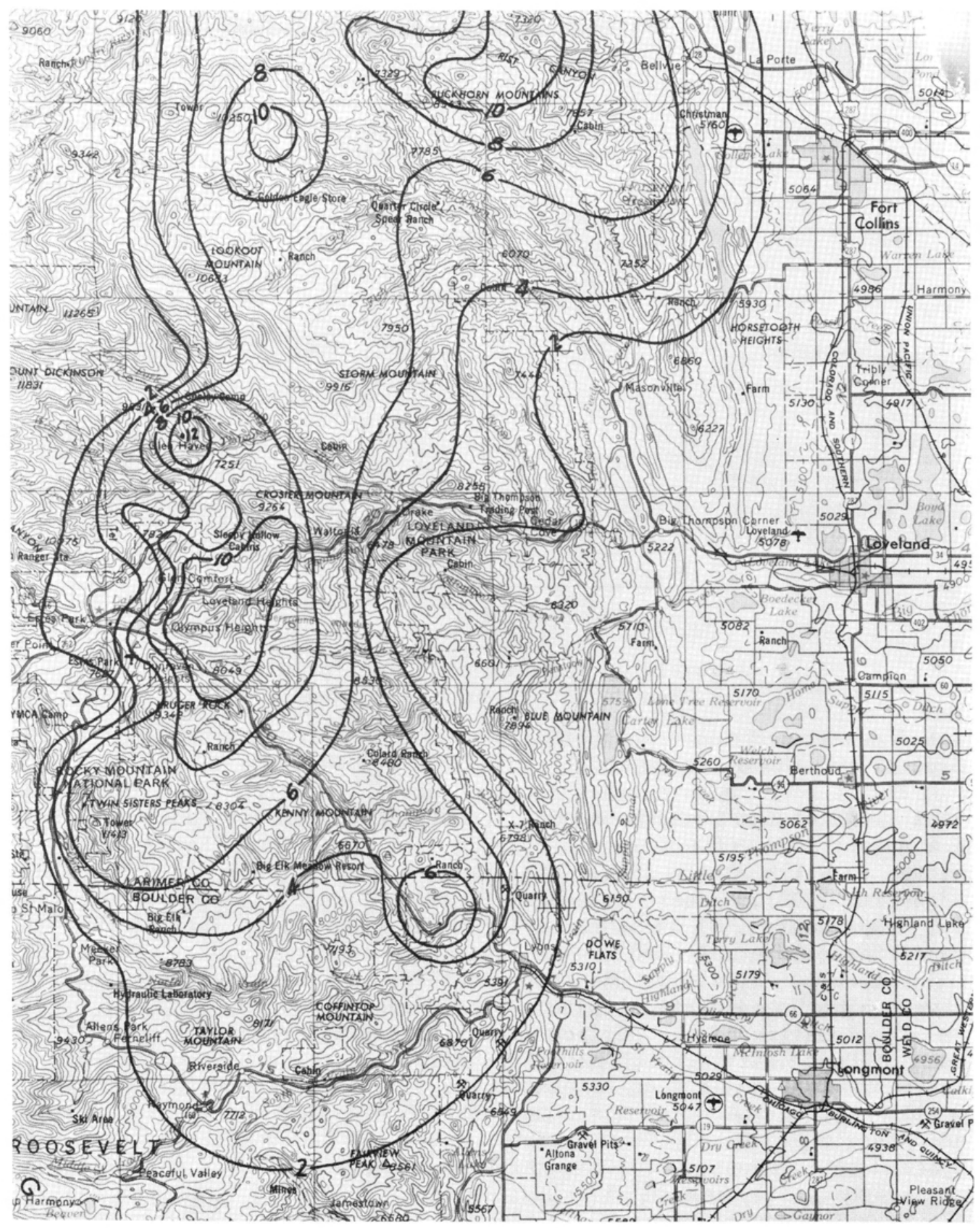

FIGURE 3 Rainfall Amounts during 31 July 1976 Storm 


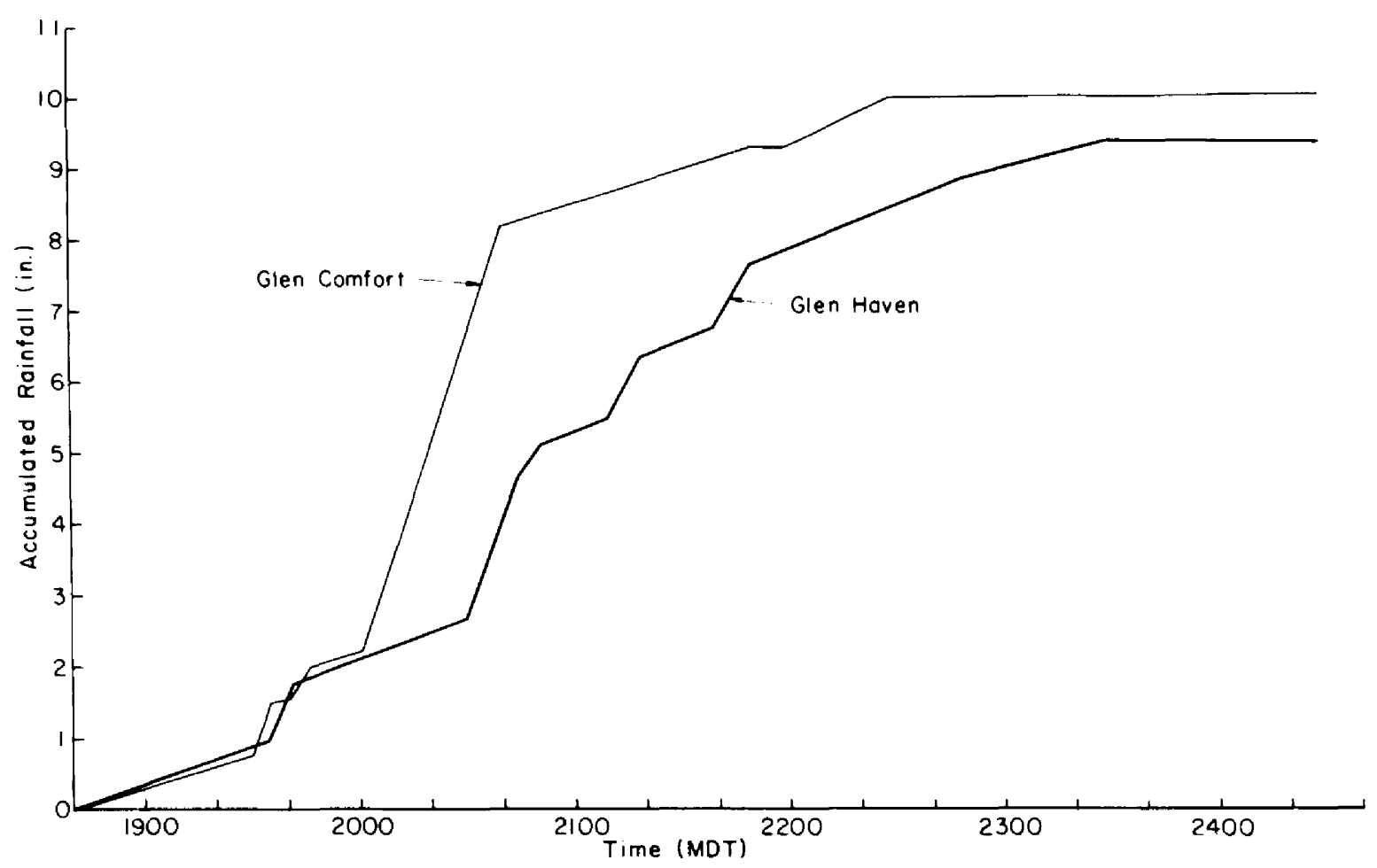

FIGURE 4 Accumulated Rainfall vs. Time for Glen Comfort and Glen Haven, 31 July 1976 (Maddox 1977)

extended westward into the foothills of the Rocky Mountains prior to the onset of the thunderstorm which caused the Big Thompson flood.

Figure 6 contains a cross section through the troposphere along the front range of the Rocky Mountains, constructed from the radiosonde data of 1 August 1976, 0000 GMT, and running from Rapid City (RAP), South Dakota, to North P1atte (LBF), Nebraska, to Denver (DEN), Colorado, to Dodge City (DDC), Kansas, to Amarillo (AMA), Texas. Isotherms of potential temperature $\left({ }^{\circ} \mathrm{K}\right)$ are entered into this diagram, as well as the boundaries of unstable and stable regions in the atmosphere. Potential temperature is defined as the temperature an air mass would acquire if it were brought adiabatically to a pressure of $1,000 \mathrm{mb}$.

The location of the surface front (Figure 5), running somewhat south of Dodge City, cannot be distinguished on the cross section of Figure 6. Instead, a deep adiabatic layer with convective mixing and cumulus cloud development was found on both sides of the frontal system indicated in Figure 5. Cumulonimbus clouds and thunderstorms were reported on 1 August, 0000 GMT, throughout the region over which this deep adiabatic layer with plentiful moisture prevailed. Maximum depth of this moist layer was reached slightly north of Denver where, subsequent to the time of this cross-sectional analysis, the flood conditions developed. Slightly farther to the north the adiabatic layer near the ground decreased abruptly in depth, signaling a suppression of convective cloud development as evident from the surface maps (Figure 5). 


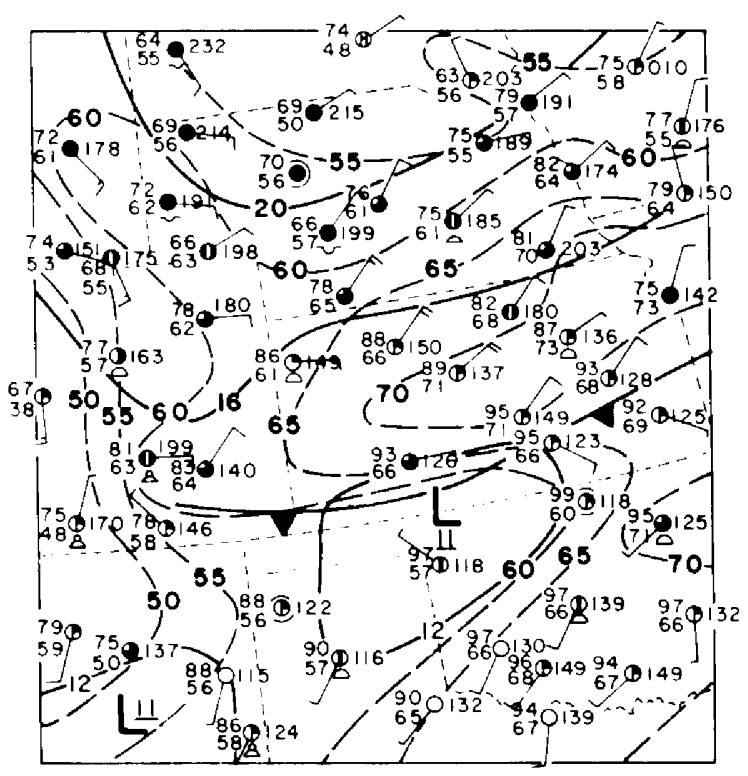

$7 / 31 / 76 / 8 \mathrm{GMT}$

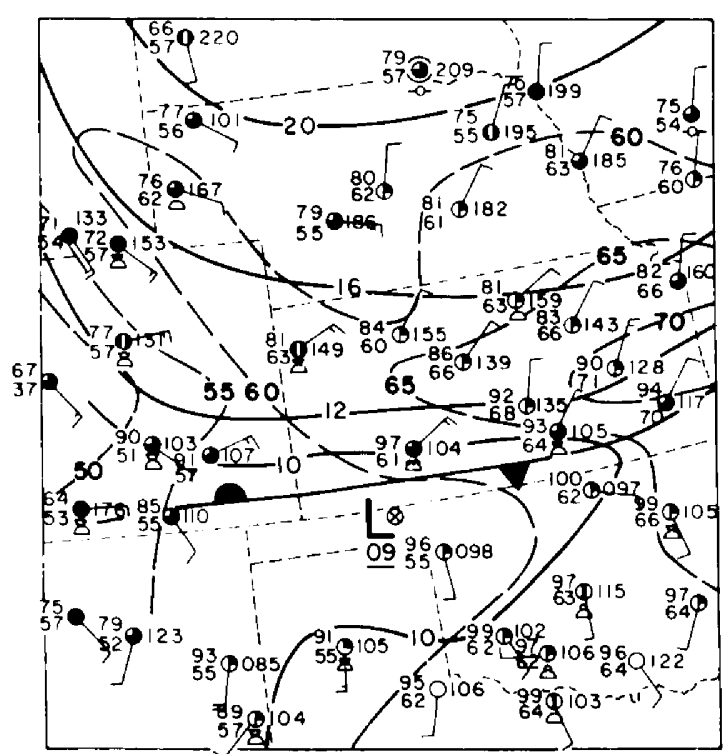

$8 / 1 / 76$ OOGMT

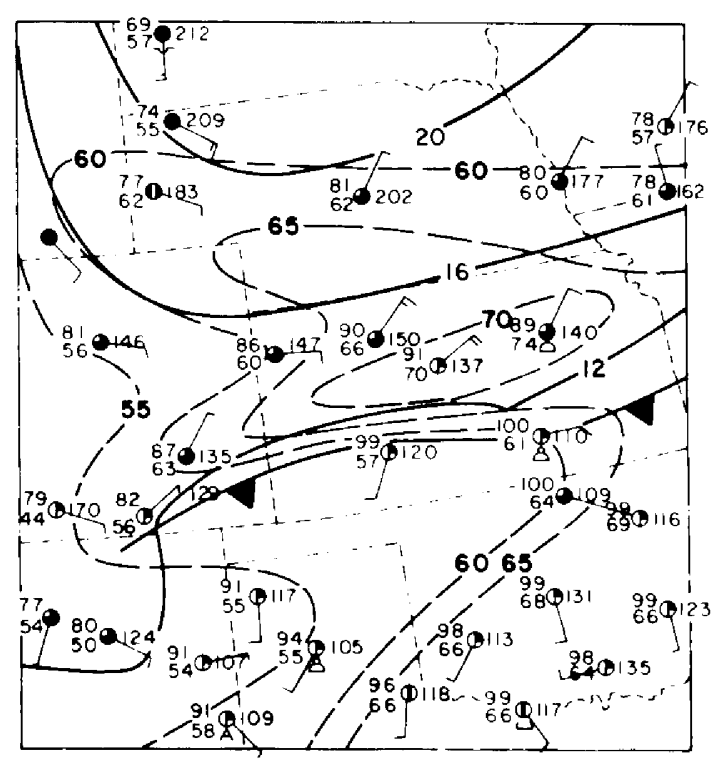

$7 / 31 / 76$ 2IGMT

FIGURE 5 Surface weather maps for the central United States. Dashed lines are isotherms of dew-point temperatures $\left({ }^{\circ} \mathrm{F}\right)$, solid lines are isobars of pressure reduced to sea level (in millibars, add 1,000). Frontal boundaries are indicated by conventional symbols. The degree of blackness of station circles signifies the amount of cloud cover. Arrows with "barbs" fly with the wind, a short barb indicating 5 knots, a long barb 10 knots. The numbers and symbols plotted around station circles mean (clockwise, starting from the right): 8 cumulus, 8 towering cumulus, $\mathbf{8}$ cumulonimbus, $\checkmark$ stratocumulus, dew-point temperatures in degrees, and temperature in degrees. 


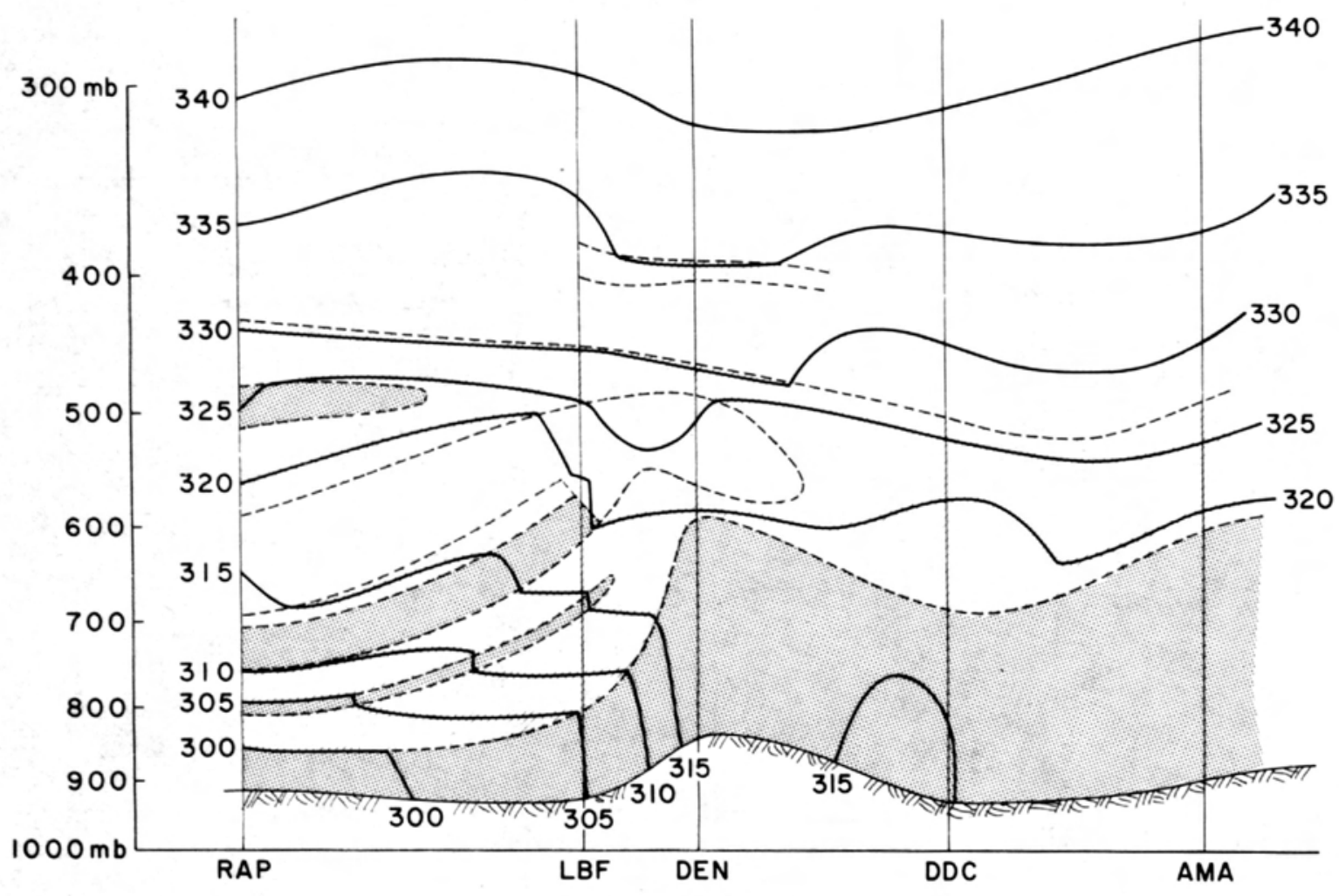

FIGURE 6 Vertical cross section of potential temperature distribution $\left({ }^{\mathrm{K}}\right)$. The horizontal coordinate is distance, running from Rapid City (RAP), South Dakota, to North Platte (LBF), Nebraska, to Denver (DEN), Colorado, to Dodge City (DDC), Kansas, to Amarillo (AMA), Texas. The vertical coordinate is labelled in millibars on an expanding scale. The dotted areas are unstable regions, crosshatched areas are stable layers. Data are extraced from the 0000 GMT sounding of 1 August 1976.

The five soundings used to construct the cross section of Figure 6 are plotted on tephigrams (abscissa = temperature; ordinate = potential temperature; slanting lines $=$ pressure) in Figure 7 , together with their dew-point temperatures. The soundings of Amarillo, Dodge City, and Denver revealed a deep adiabatic layer close to the ground, characterized by nearly uniform water-vapor mixing ratios in this layer, as indicated by the plotted dew-point temperature distributions. The uniformity of the water-vapor mixing ratio was indicative of convective mixing taking place in this layer. Dew-point temperatures close to saturation were reached at the top of the deep adiabatic layer. The atmosphere above the top of this layer was conditionally unstable for moist-adiabatic processes, meaning that a short penetration of convective motions from the adiabatic layer into the stable layer above it will suffice to set off cumulus cloud development which will grow rapidly into the relatively unstable middle and upper troposphere. Enough moisture was present in the deep adiabatic layer close to the ground to feed the 


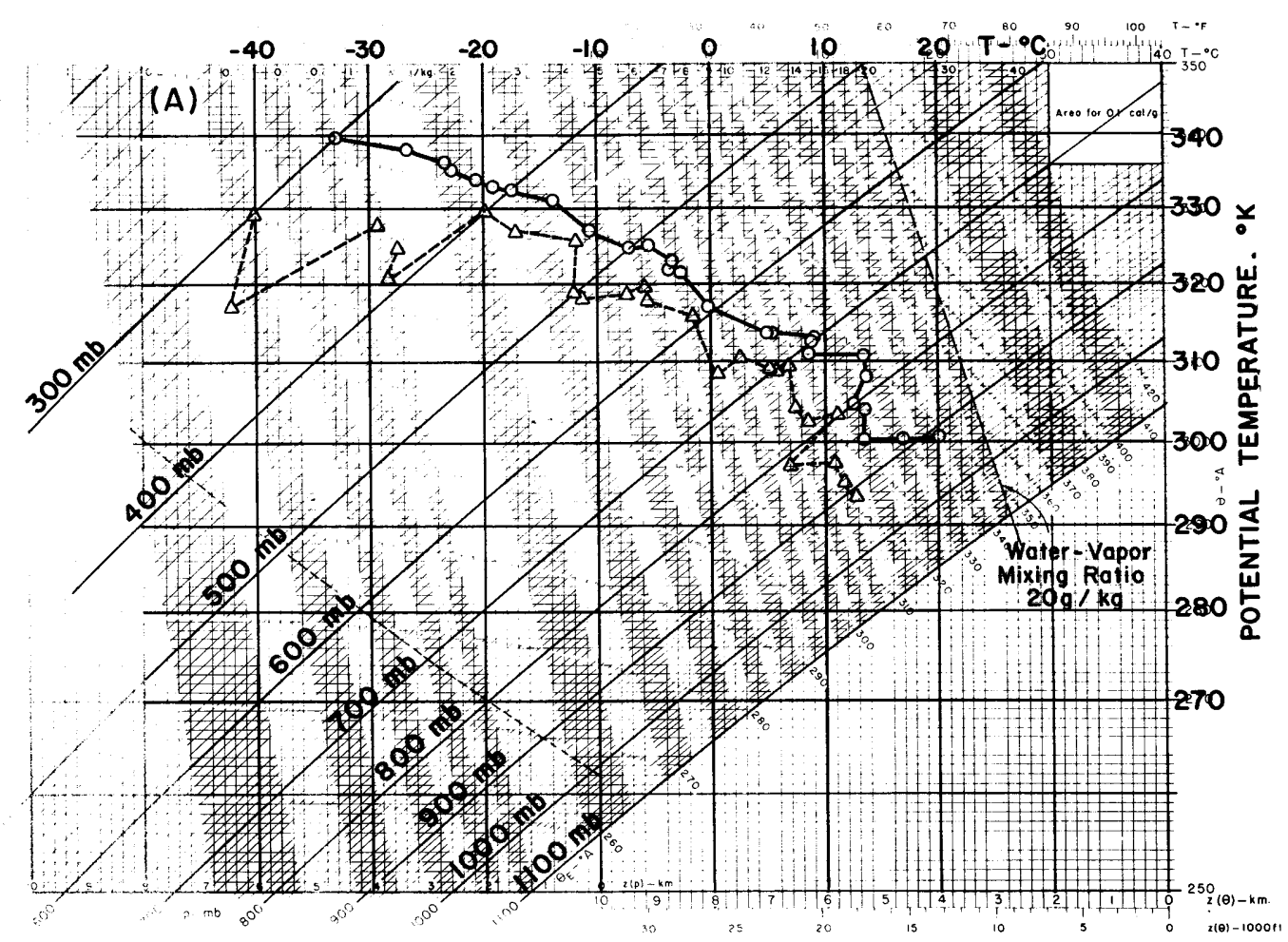

FIGURE 7a Rapid City, South Dakota

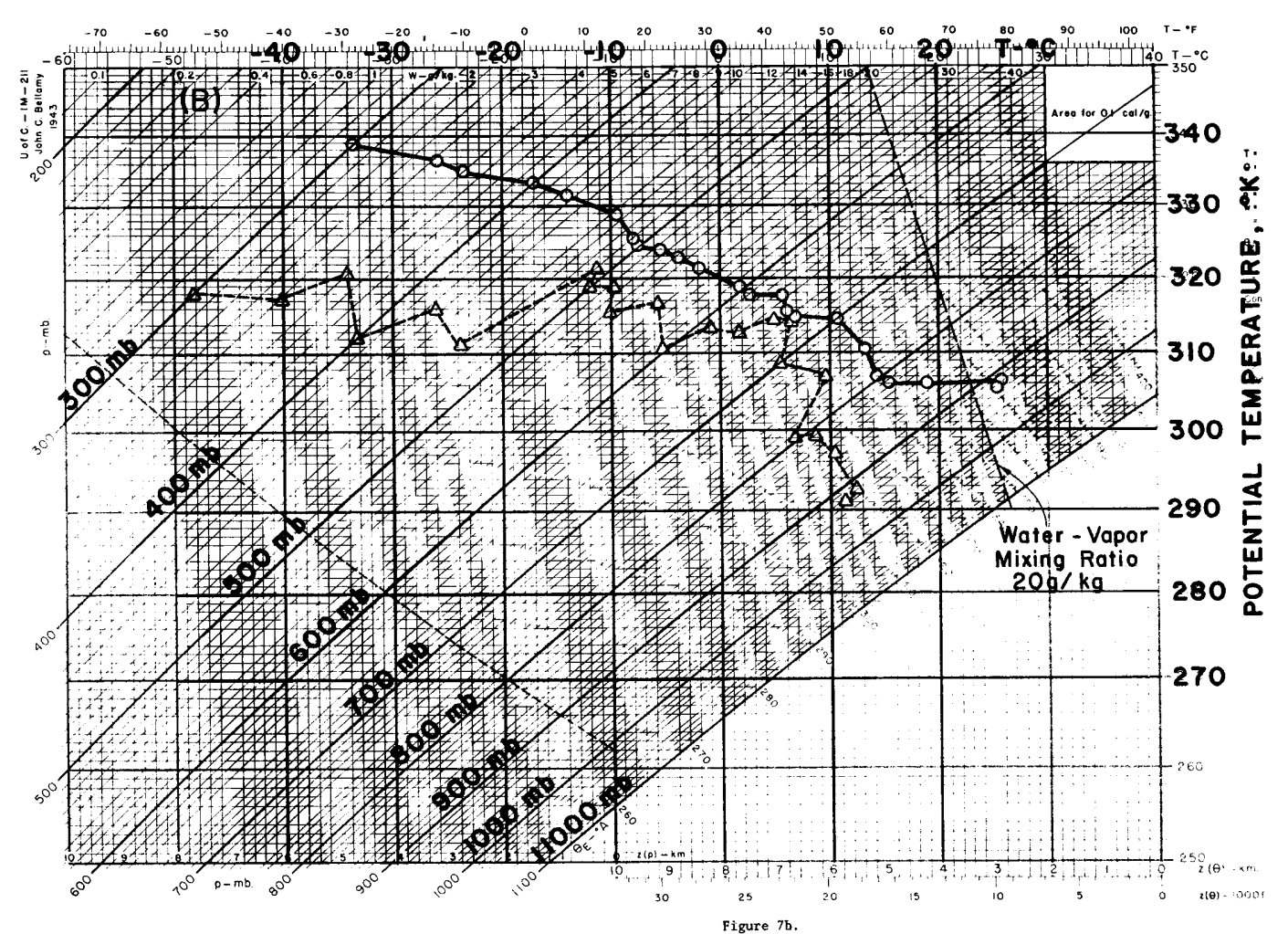

FIGURE $7 b$ North P1atte, Nebraska 


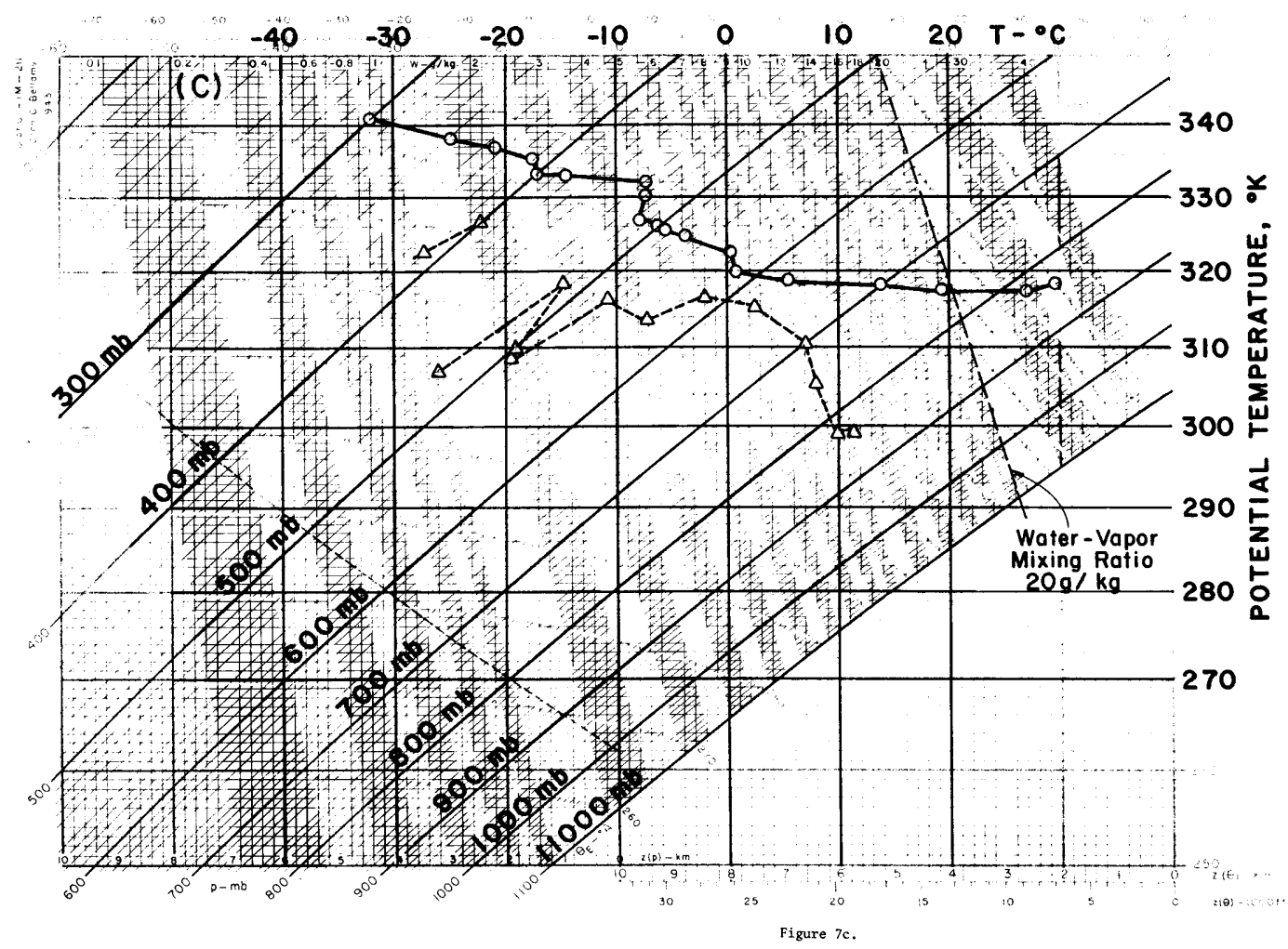

FIGURE 7c Denver, Colorado

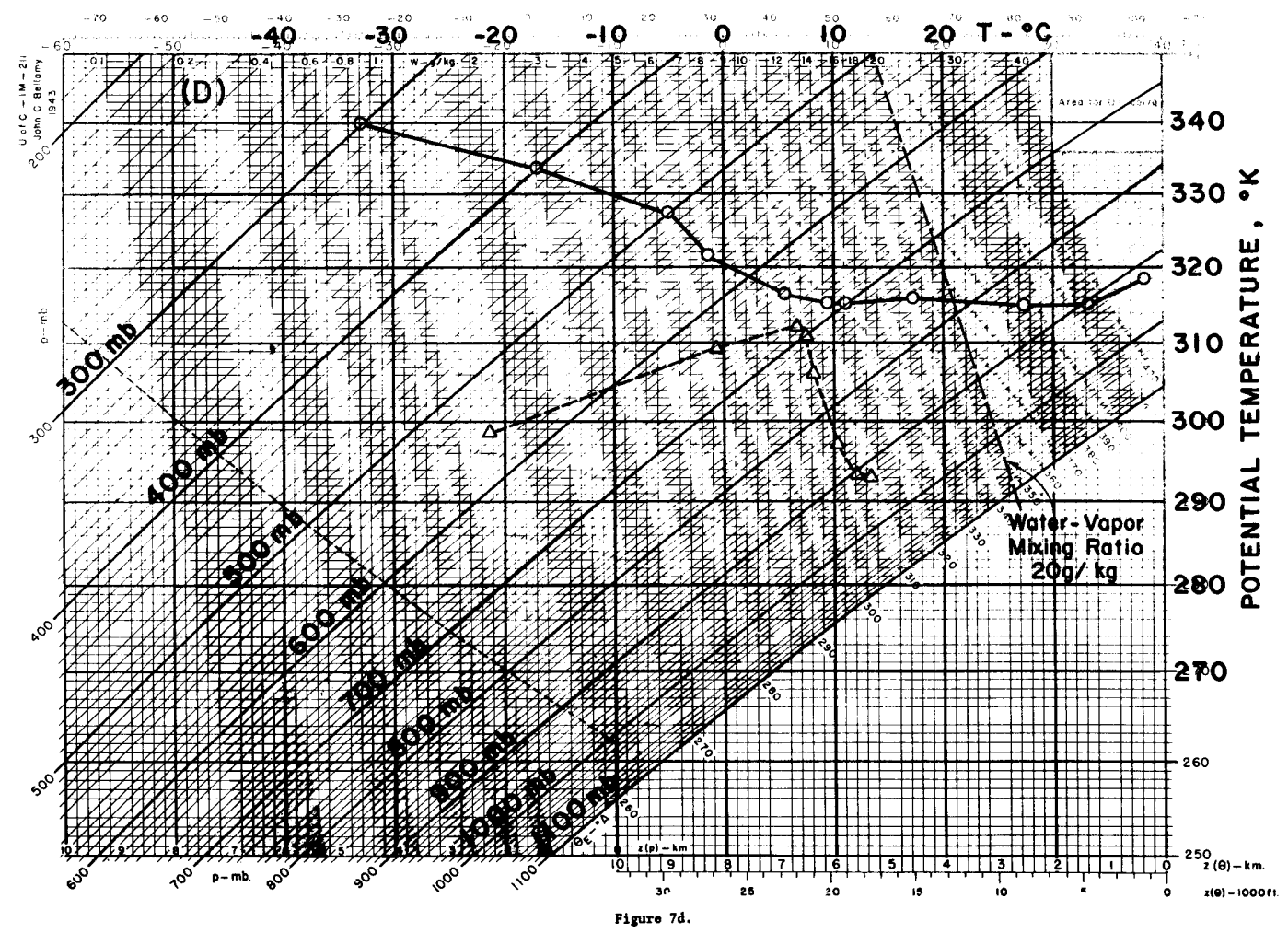

FIGURE 7d Dodge City, Kansas 


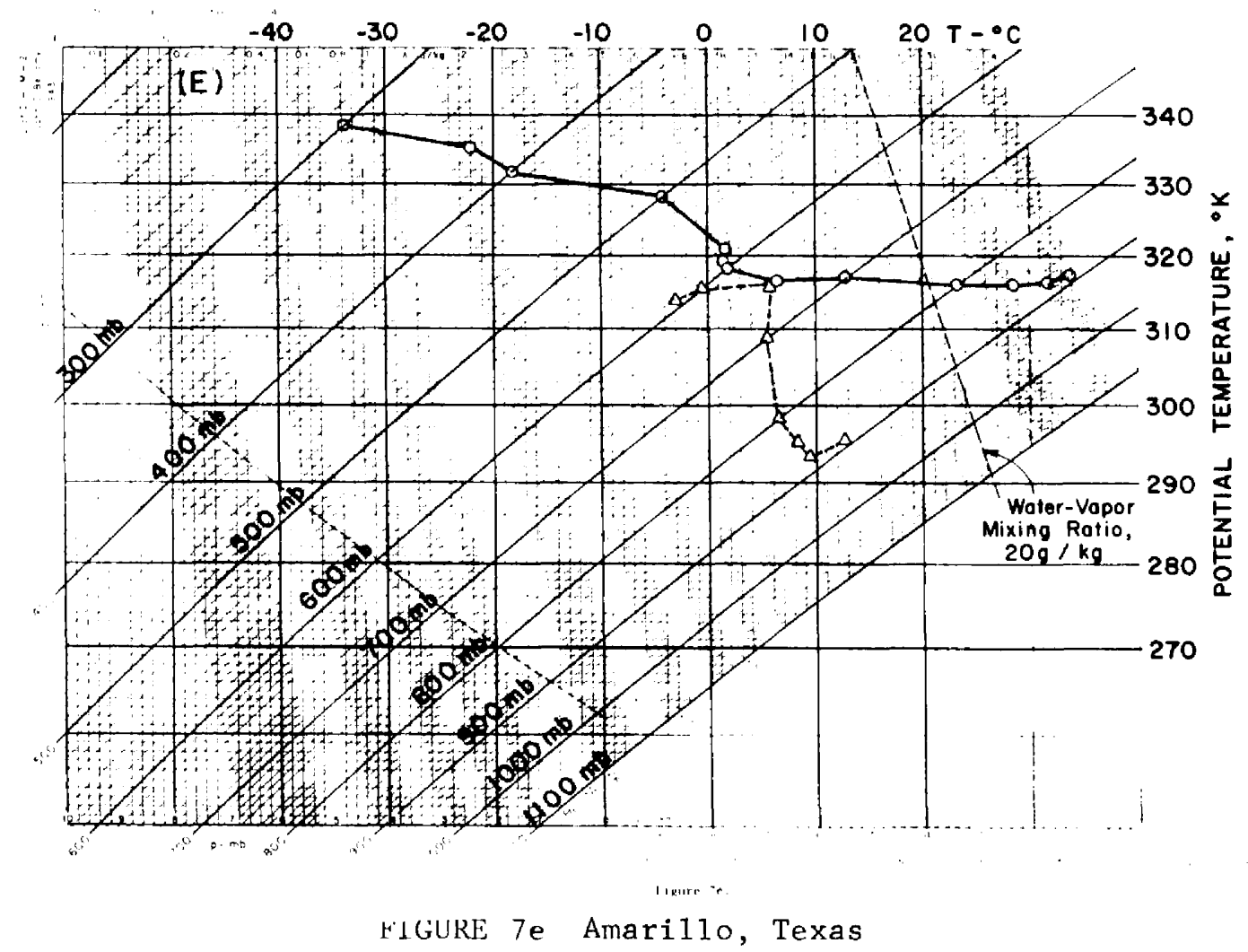

FIGURE 7 Vertical sounding of the atmosphere plotted in thermodynamic diagrams for the 0000 GMT 1 August 1976 observations at the indicated stations. The following codes are used:

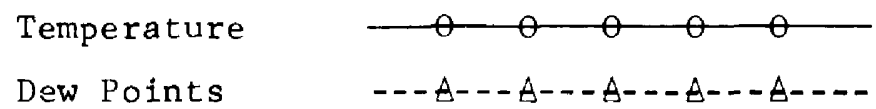

The horizontal coordinate in these diagrams is temperature $\left({ }^{\circ} \mathrm{C}\right)$, the vertical coordinate is potential temperature $\left({ }^{\circ} \mathrm{K}\right)$. The lines sloping from the lower left to the upper right indicate pressure (mb). The dashed line slanting towards the left is a line of constant water-vapor mixing ratio at $20 \mathrm{gm}$ of water per $\mathrm{kg}$ of air.

cumulonimbus development once the "convective chimney" was established. From the relative depth of the adiabatic layer (Figure 6) one should expect that strongest thunderstorm development should occur in the vicinity of Denver.

Under normal summertime conditions westerly winds, albeit weak ones, prevail in the middle and upper troposphere over colorado. These winds tend to move the convective cells toward the east, once they develop in the early afternoon. Major initial development takes place near the Continental Divide, supported by the upslope motion along a terrain surface which has been heated by solar radiation. Dirks (1970) has studied the development of convective precipitation systems over 

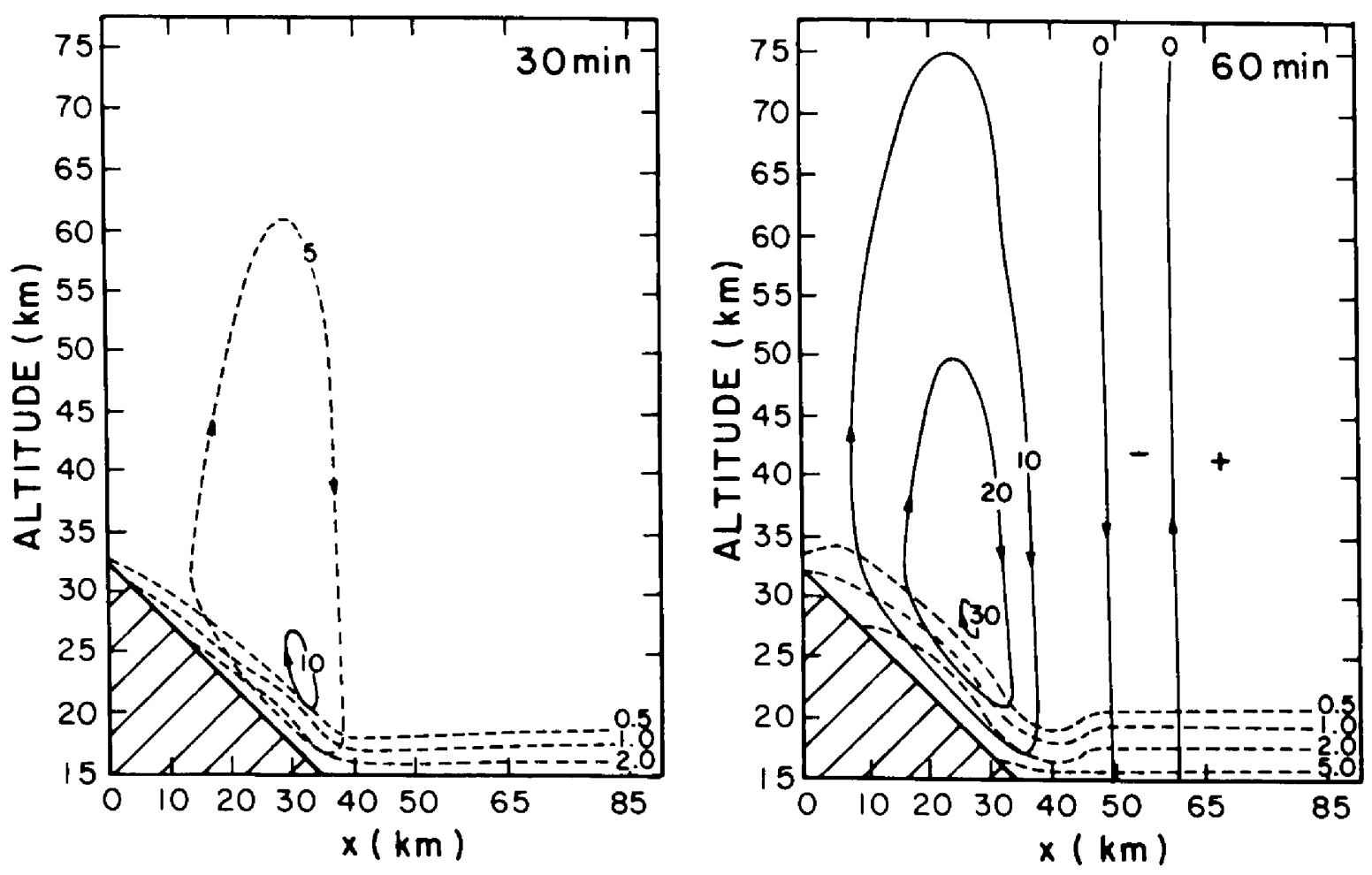

FIGURE 8 Dirks (1970) model of the evolution of the stream function, $x$ (solid lines, in $10^{2} \mathrm{~m}^{2} / \mathrm{sec}$ ) and potential temperature deviation (dashed lines, in ${ }^{\circ} \mathrm{C}$ ) for the case with a deep adiabatic layer in the lower troposphere with essentially calm conditions in the troposphere at initial time. Vertical velocities, w, in these diagrams are inversely proportional to the distance between isolines of $X$ since $\mathrm{w}=\Delta \mathrm{x} / \Delta \mathrm{x}$, where $\mathrm{x}$ is the horizontal distance.

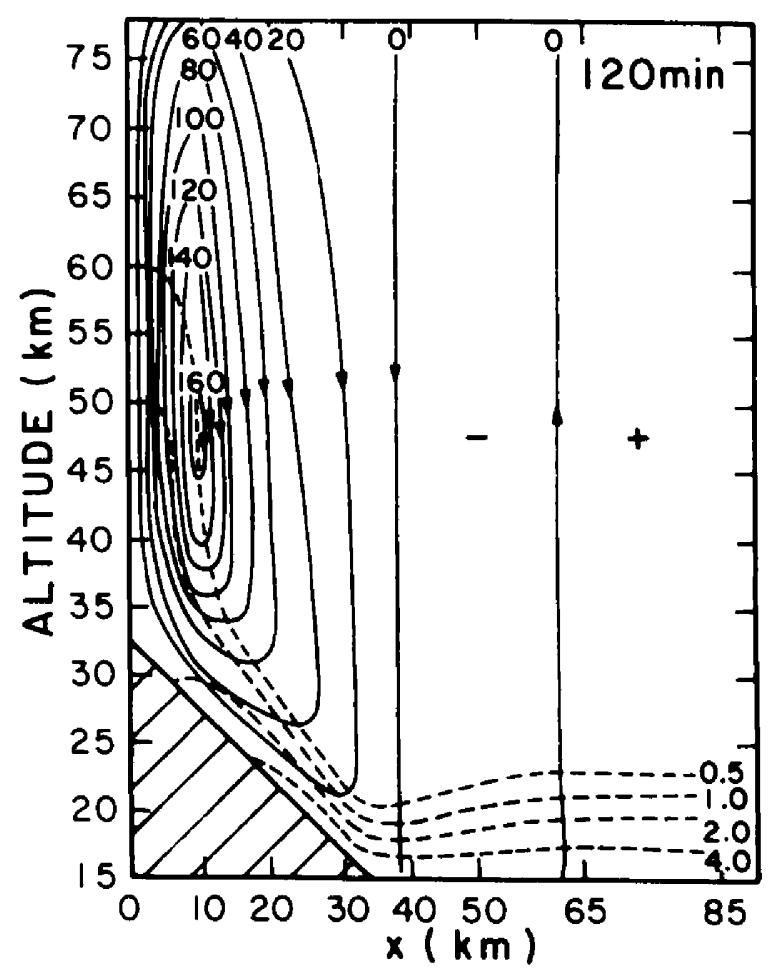


the mountains, using a numerical modeling approach. Figure 8 shows the model calculations for the case of a deep adiabatic layer in the lower troposphere and essentially calm conditions in the troposphere at initial time. Westerly winds in the troposphere tend to reduce the intensity and depth of the convective cells over the mountain slopes.

The middle and upper tropospheric flow conditions on 1 August 1976 are depicted in Figure 9. They show nearly calm conditions over central Colorado, or weak southerly flow more or less parallel to the Continental Divide. The model calculations of Figure 8 , therefore, appear to be applicable, which should indicate the development of an extremely strong convective cell in the upper reaches of the terrain inclined towards the Continental Divide.

In summary, the large-scale weather conditions leading to the Big Thompson flood can be described as follows. A deep adiabatic layer near the ground, laden with moisture, reached its greatest vertical extent in the vicinity of Denver. Easterly winds at low levels and calm-to-southerly winds in the middle and upper troposphere would tend to maximize the effect of terrain on convective cloud development. Model calculations indicate that strongest convective activity should be expected about 10 to $20 \mathrm{~km}$ east of the Continental Divide and in the region where the lowtropospheric, moist adiabatic layer reached its maximum depth. Under the prevailing tropospheric wind conditions, the developing thunderstorm cells would not be expected to move toward the east--as they usually do-but to become stationary after an initial slow movement toward the northwest or north.

Figure 10 shows a sequence of plots of radar echos observed at Limon. A thunderstorm cell drifted slowly in the northwesterly direction through the Denver area, almost opposite to the direction in which summer thunderstorms tend to drift. In the "bowl" of Estes Park the cell became almost stationary and intensified considerably (0025Z on 1 August until about 0300Z). At last it moved off in a northerly direction, weakening in the process. An abundant supply of moisture was assured for the maintenance and intensification of this cell as it settled over the Big Thompson valley. This is indicated by the orientation of the tongue of high dew-point temperatures in Figure 5, and by the inordinate depth of the adiabatic layer shown in Figure 6 . Because of the weak, almost calm, tropospheric winds almost no steering force was exerted on the thunderstorm cell once it had grown to full intensity. The ridge that forms the eastern edge of the bowl supported by the bowl configuration of the Estes Park area most 1ikely helped in "anchoring" the storm to a fixed location. The authors still vividly recall the jet-black sky over the upper Big Thompson valley which, viewed from Fort Collins, completely obscured Longs Peak and foreboded a downpour of rare intensity.

(Text continues on page 20.) 

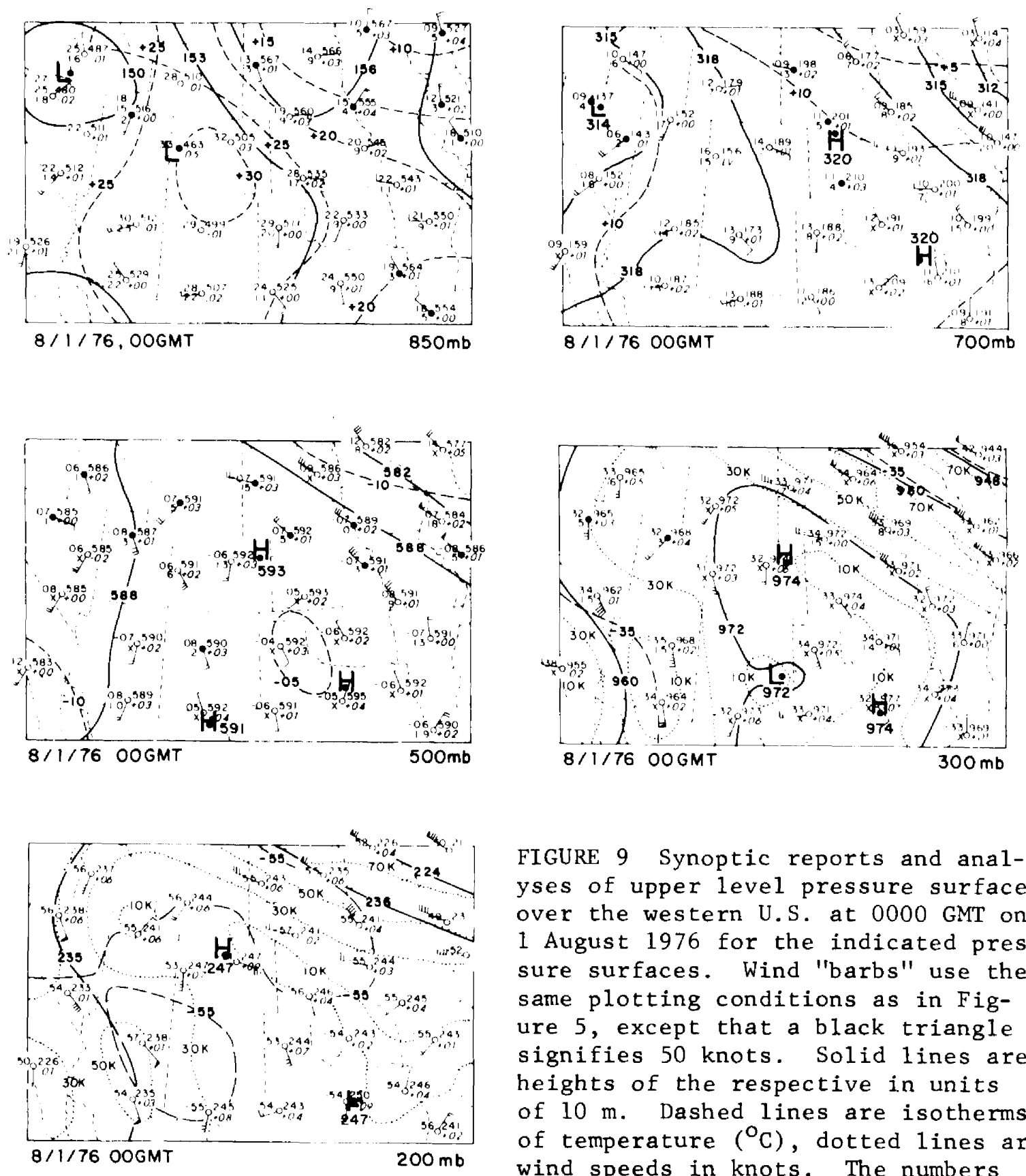

FIGURE 9 Synoptic reports and analyses of upper level pressure surfaces over the western U.S. at 0000 GMT on 1 August 1976 for the indicated pressure surfaces. Wind "barbs" use the same plotting conditions as in Figure 5, except that a black triangle signifies 50 knots. Solid lines are heights of the respective in units of $10 \mathrm{~m}$. Dashed lines are isotherms of temperature $\left({ }^{\circ} \mathrm{C}\right)$, dotted lines are wind speeds in knots. The numbers around station circles indicate (clockwise, starting from the right): height of the surface in units of 10 $\mathrm{m}$, height change during the last 12 hours in units of $10 \mathrm{~m}$, dew-point temperature $\left({ }^{\circ} \mathrm{C}\right)$ ( $x$ indicates missing data; dew-point temperatures are not reported on the $200 \mathrm{mb}$ pressure leve1), actual temperature $\left({ }^{\circ} \mathrm{C}\right)$. 

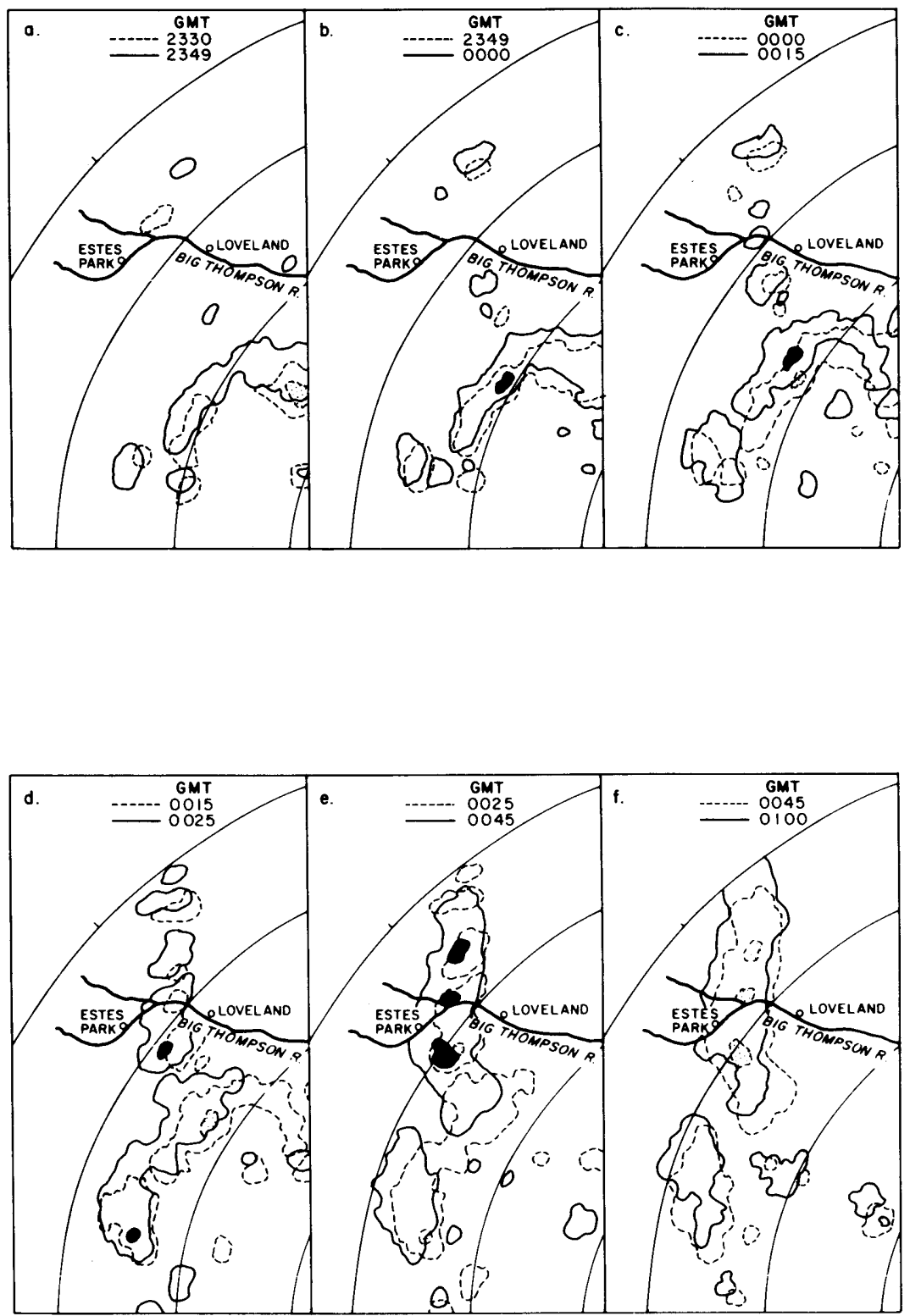

FIGURE 10a 

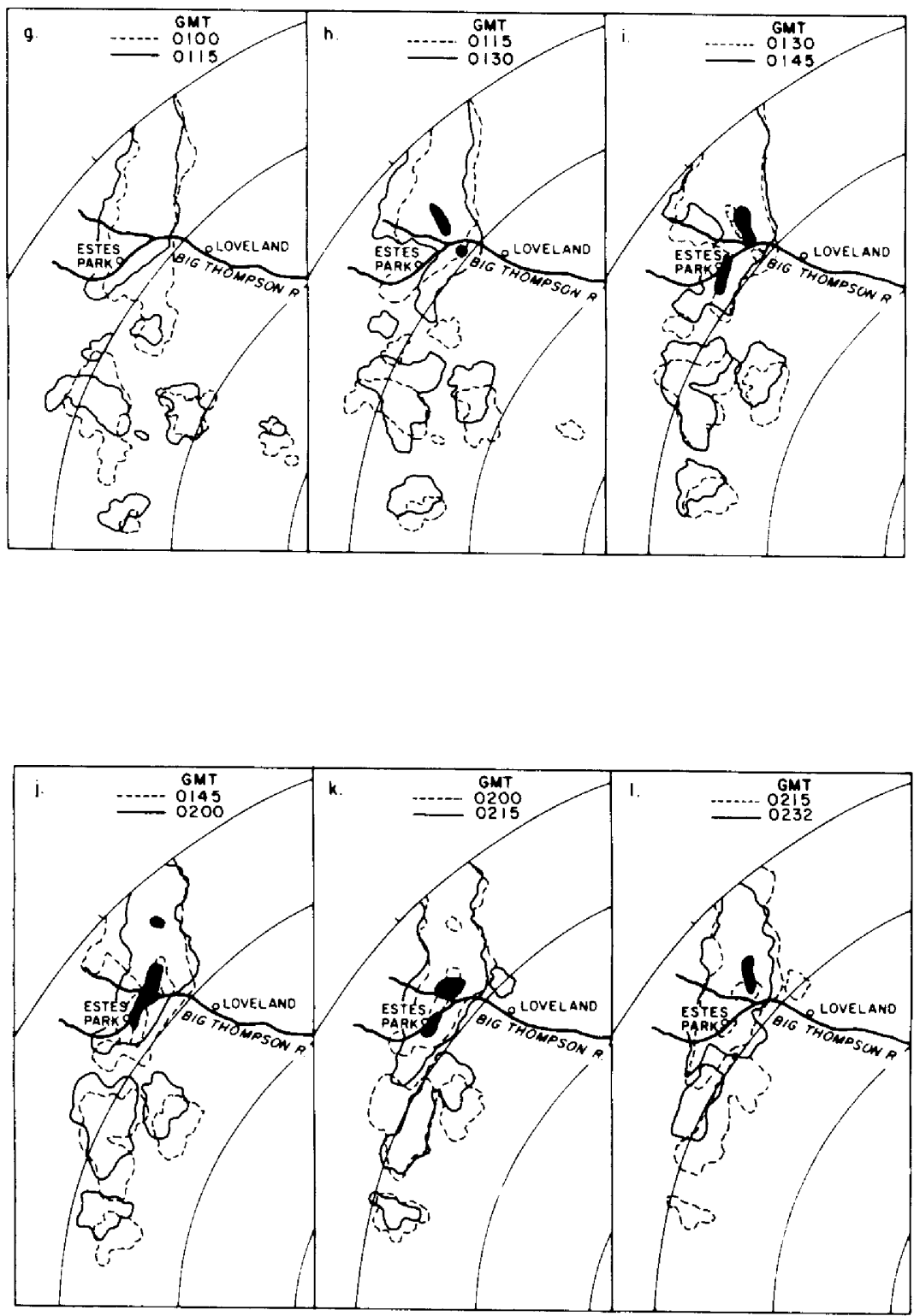

FIGURE 10b 

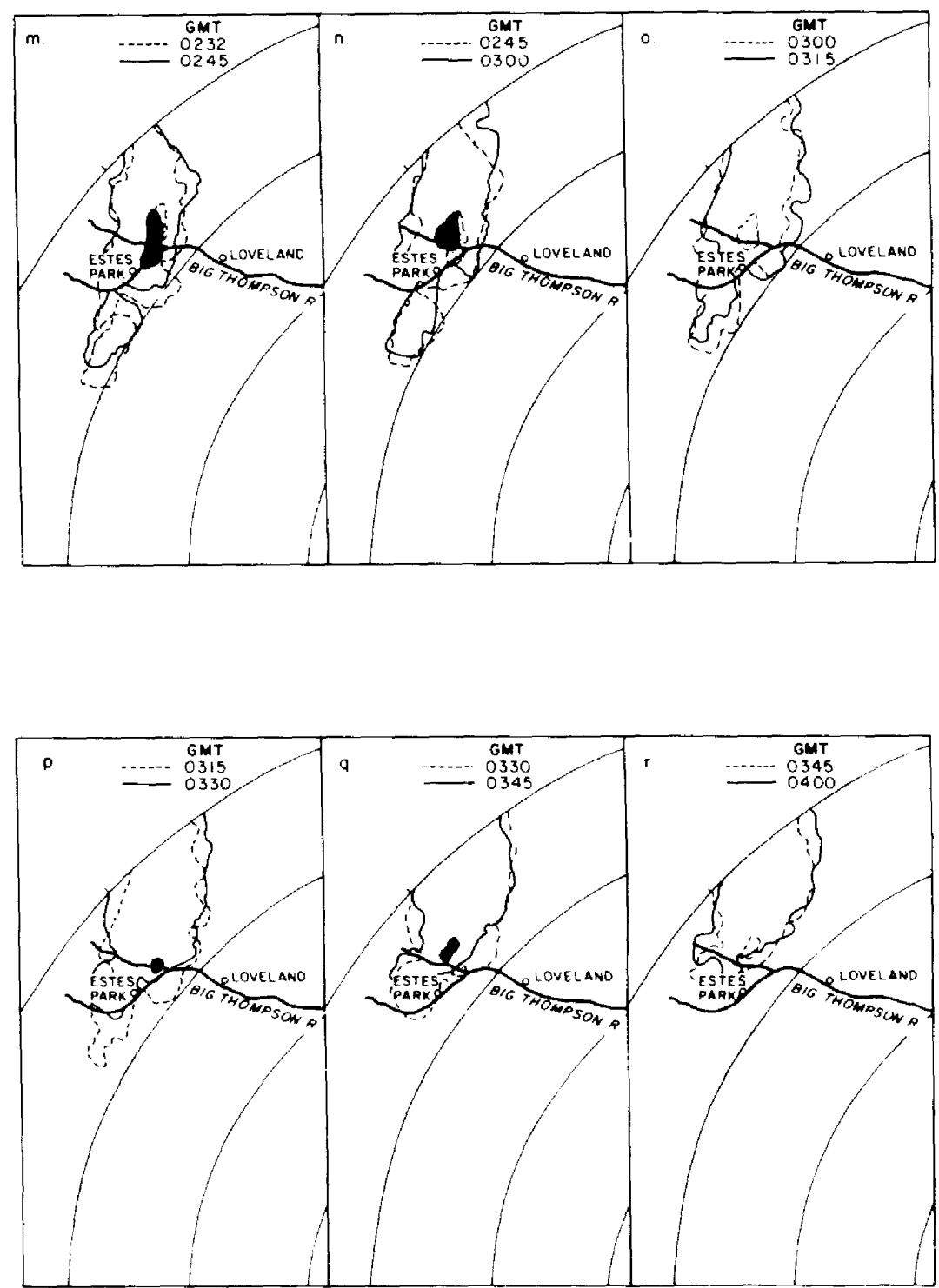

FIGURE $10 \mathrm{c}$

FIGURE 10 A series of radar echo configurations derived from the Limon radar data for $31 \mathrm{July} 1976$ and 1 August 1976. Each frame shows the outlines of intensity level 1 and level 3 echoes at the beginning and end of the indicated time period according to the following code.

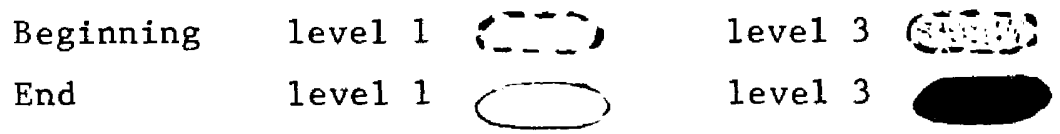

The map indicates the location of the Big Thompson River along with nearby cities. 
FLOOD DISCHARGE

In general, the Big Thompson flood was due to heavy rainfall in the mountains between Glen Comfort and Glen Haven. The rainfall produced high rates of runoff on tributaries of the Big Thompson and the North Fork rivers above Drake. The resulting flash flood peaked at the canyon mouth at $31,200 \mathrm{cfs}$, alnost four times greater than the previous recorded maximum. As this flood wave moved out onto the plains, overbank storage quickly attenuated the flood peak. At its confluence with the South Platte river at LaSalle, Colorado, the Big Thompson river had a peak discharge of $2,470 \mathrm{cfs}$ on 1 August 1976. Table 2 is a summary of the flood data; the location of discharge sites are shown in Figures $11-13$.

Big Thompson River: Upstream from Drake

The area upstream from Drake includes the portion of the basin extending from Olympus dam downstream to Drake, as shown in Figure 11 . The drainage area between Loveland Heights and Waltonia bore the brunt of the 31 July storm and produced much of the flood runoff. Other portions of this area received heavy rainfall, but either produced little significant runoff or peaked well after the major flood crested downstream.

The area above olympus dam contributed little to the flooding downstream. Light rainfall raised water levels on the streams above Lake Estes but caused only minor flooding. At $2055 \mathrm{MDT}$, the gates of 01ympus dam were closed, cutting off flow from upstream. The 108 cfs which was being released prior to closure was very small compared to the flood discharge downstream. Consequently, the area above Olympus dam can be considered non-contributing.

From Olympus dam to Loveland Heights, only two tributaries produced a significant amount of runoff. A small unnamed tributary that drains an area southeast of Lake Estes showed signs of a substantial discharge. No discharge was determined for this stream but it is estimated that a large peak occurred between 1900 and 2100 MDT. Dry Gulch, which drains an area of 6.12 square miles northeast of Estes Park, received heavy rainfall in upper portions of its basin at approximately 2200 MDT. Dry Gulch, near Estes Park (site $3 *$ ), had a peak discharge of 4,460 cfs at 2230 MDT. The peak discharge of the Big Thompson river upstream from Loveland Heights (site 6) was estimated to be 4,330 cfs at 2300 MDT. Since residents reported no high water prior to this rise, the rise must have come primarily from Dry Gulch. Also, since this peak occurred well after the major flooding downstream, the area contributed very little to the major flood peak.

The area from Loveland Heights to Waltonia received the heaviest rainfall between 1930 and $2100 \mathrm{MDT}$, and produced the majority of the runoff. Tributaries along this reach yielded high rates of runoff and experienced severe channel erosion. Dark Gulch (site 8), a north bank tributary with its mouth near Glen Comfort, had a peak discharge of 7,210 cfs from a drainage area of 1.00 square miles. This is a new *Sites are shown in Table 2 and Figures 11,12 , and 13. 
TABLE 2

Summary of Discharges in Big Thompson River Flood (McCain 1977)

\begin{tabular}{|c|c|c|c|c|c|c|c|c|c|}
\hline $\begin{array}{l}\text { Site* } \\
\text { No. }\end{array}$ & Station & $\begin{array}{c}\text { Drainage } \\
\text { Area } \\
\left(\mathrm{Mi}^{2}\right)\end{array}$ & $\begin{array}{l}\text { Date } \\
(1976)\end{array}$ & $\begin{array}{l}\text { Time } \\
(\mathrm{MDT})\end{array}$ & Source非 & $\begin{array}{c}\text { Gage } \\
\text { Height } \\
\text { (ft) }\end{array}$ & $\begin{array}{l}\text { Depth } \\
(\mathrm{ft})\end{array}$ & $\begin{array}{l}\text { Average } \\
\text { Velocity } \\
\text { (ft/sec) }\end{array}$ & $\begin{array}{l}\text { Disçharge } \\
\left(\mathrm{ft}^{3} / \mathrm{sec}\right)\end{array}$ \\
\hline 1 & $\begin{array}{l}\text { Big Thompson River at } \\
\text { Estes Park }\end{array}$ & 137 & $7-31$ & 2130 & Gage & 3.64 & -- & -- & 457 \\
\hline 2 & Fish Creek near Estes Park & 16.0 & $7-31$ & 2150 & Gage & 4.02 & $\cdots$ & -- & 182 \\
\hline 3 & $\begin{array}{l}\text { Big Thompson River near } \\
\text { Estes Park }\end{array}$ & 155 & $7-31$ & 2055 & -- & -- & -- & -- & $100 * *$ \\
\hline 4 & Dry Gulch near Estes Park & 2.00 & $7-31$ & 2215 & S.A. & -- & 3.3 & 12 & 3,210 \\
\hline 5 & Dry Gulch at Estes Park & 6.12 & $7-31$ & 2230 & S.A. & - & --- & -- & 4,460 \\
\hline 6 & $\begin{array}{l}\text { Big Thompson River above } \\
\text { Loveland Heights }\end{array}$ & 164 & $7-31$ & 2300 & S.A. & -- & 4.6 & 8 & 4,330 \\
\hline 7 & $\begin{array}{l}\text { Tributary of Big Thompson River } \\
\text { below Loveland Heights }\end{array}$ & 1.37 & $7-31$ & -- & S.A. & -- & 5.5 & 26 & 8,700 \\
\hline 8 & Dark Gulch at Glen Comfort & 1.00 & $7-31$ & -- & S.A. & -- & 5.1 & 28 & 7,210 \\
\hline 9 & Noels Draw at Glen Comfort & 3.37 & $7-31$ & -- & S.A. & -- & 5.7 & 21 & 6,910 \\
\hline 10 & Rabbit Gulch near Drake & 3.41 & $7-31$ & -- & S.A. & -- & 4.7 & 13 & 3,540 \\
\hline 11 & Long Gulch near Drake & 1.99 & $7-31$ & -- & S.A. & -- & 5.8 & 19 & 5,500 \\
\hline 12 & $\begin{array}{l}\text { Big Thompson River above } \\
\text { Drake }\end{array}$ & 189 & $7-31$ & 2100 & S.A. & -- & 8.3 & 22 & 28,200 \\
\hline 13 & $\begin{array}{l}\text { North Fork Big Thompson River } \\
\text { at Glen Haven }\end{array}$ & 18.5 & $7-31$ & -- & S.A. & -- & 2.2 & 8 & 888 \\
\hline 14 & Fox Creek at Glen Haven & 7.18 & $7-31$ & -- & S.A. & -- & 2.8 & 9 & 1,300 \\
\hline 15 & West Creek near Glen Haven & 23.1 & $7-31$ & -- & S.A. & -- & 3.0 & 7 & 2,320 \\
\hline 16 & Devils Gulch near Glen Haven & 0.91 & $7-31$ & -- & S.A. & -- & 2.1 & 12 & 2,810 \\
\hline 17 & $\begin{array}{l}\text { Tributary of North Fork Big } \\
\text { Thompson River near Glen Haven }\end{array}$ & 1.38 & $7-31$ & -- & S.A. & -- & 5.6 & 29 & 9,670 \\
\hline 18 & Black Creek near Glen Haven & 3.17 & $7-31$ & 2300 & S.A. & -- & 4.5 & 11 & 1,990 \\
\hline 19 & Miller Fork near Glen Haven & 13.9 & $7-31$ & 2300 & S.A. & -- & 3.6 & 12 & 2,060 \\
\hline 20 & $\begin{array}{l}\text { Tributary of North Fork Big } \\
\text { Thompson River near Drake }\end{array}$ & 1.26 & $7-31$ & -- & S.A. & -- & 3.0 & 18 & 3,240 \\
\hline 21 & $\begin{array}{l}\text { North Fork Big Thompson River } \\
\text { at Drake }\end{array}$ & 85.1 & $7-31$ & 2140 & Gage & 9.21 & 5.2 & 12 & 8,710 \\
\hline 22 & Big Thompson River below Drake & 276 & $7-31$ & 2115 & Gage & -- & 10.3 & 16 & 30,100 \\
\hline 23 & $\begin{array}{l}\text { Big Thompson River at mouth of } \\
\text { Canyon near Drake }\end{array}$ & 305 & $7-31$ & 2140 & $\begin{array}{l}\text { Gage \& } \\
\text { S.A. }\end{array}$ & 19.69 & 10.6 & 26 & 31,200 \\
\hline 24 & $\begin{array}{l}\text { Big Thompson River below Green } \\
\text { Ridge Glade near Loveland }\end{array}$ & 311 & $7-31$ & -- & S.A. & -- & 6.7 & 12 & 27,000 \\
\hline 25 & Redstone Creek near Masonville & 29.1 & $8-1$ & -- & Gage & -- & 4.2 & 10 & 2,640 \\
\hline 26 & Buckhorn Creek near Masonville & 131 & $8-1$ & - & Gage & 8.1 & -- & -- & 3,400 \\
\hline 27 & $\begin{array}{l}\text { Big Thompson River at mouth } \\
\text { near LaSalle }\end{array}$ & 828 & $8-1$ & 2235 & Gage & 7.82 & $-\cdots$ & -- & 2,470 \\
\hline
\end{tabular}

*Location of sites shown in Figures 11,12 , and 13

非low data were obtained from stream gaging records or from a discharge estimate using the slope area (S.A.) method.

**The gates of 01ympus dam were closed at 2055 before which $100 \mathrm{cfs}$ was being released. 


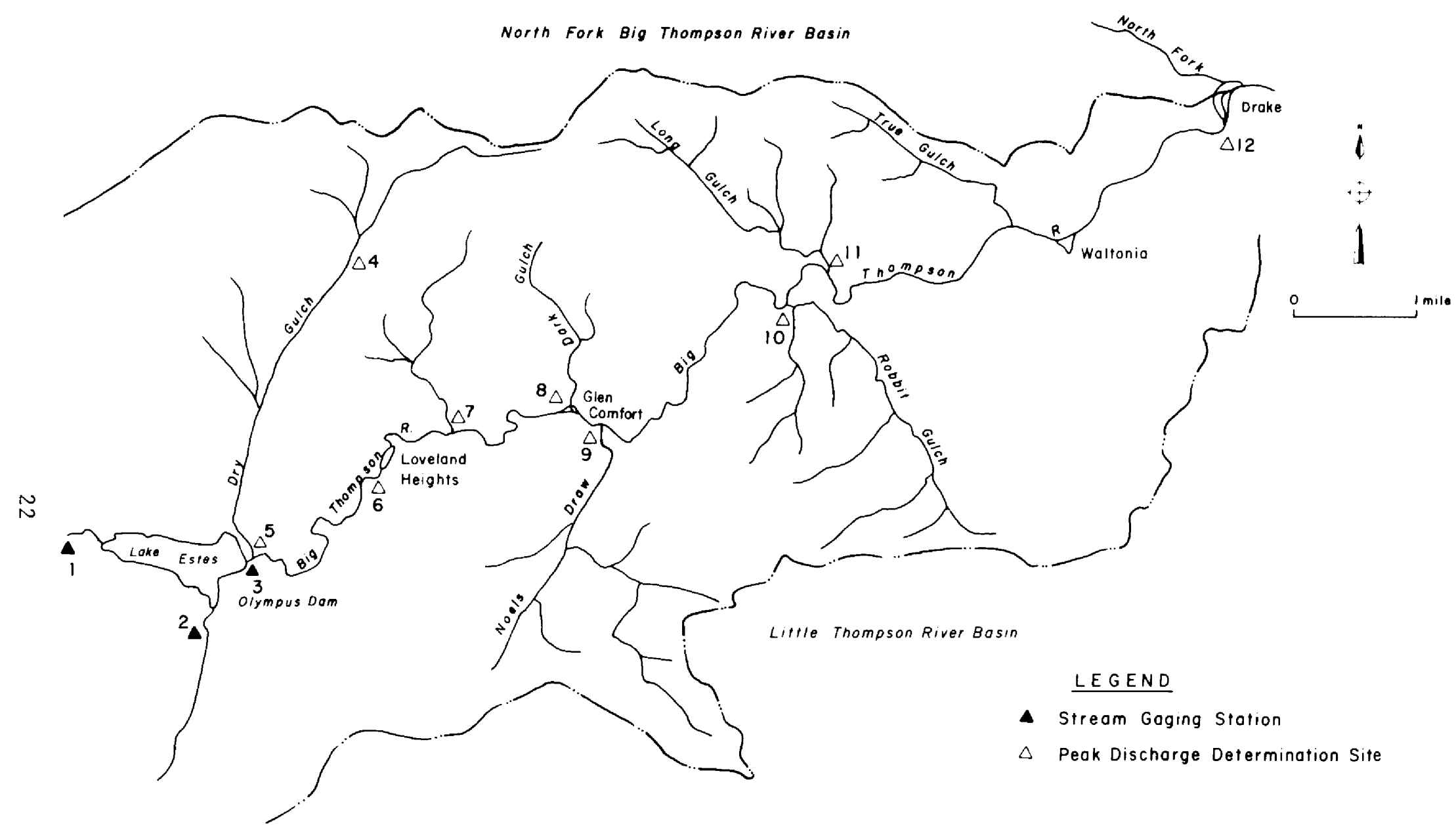

FIGURE 11 Discharge Sites on the Big Thompson River above Drake for the 31 July 1976 Flood 


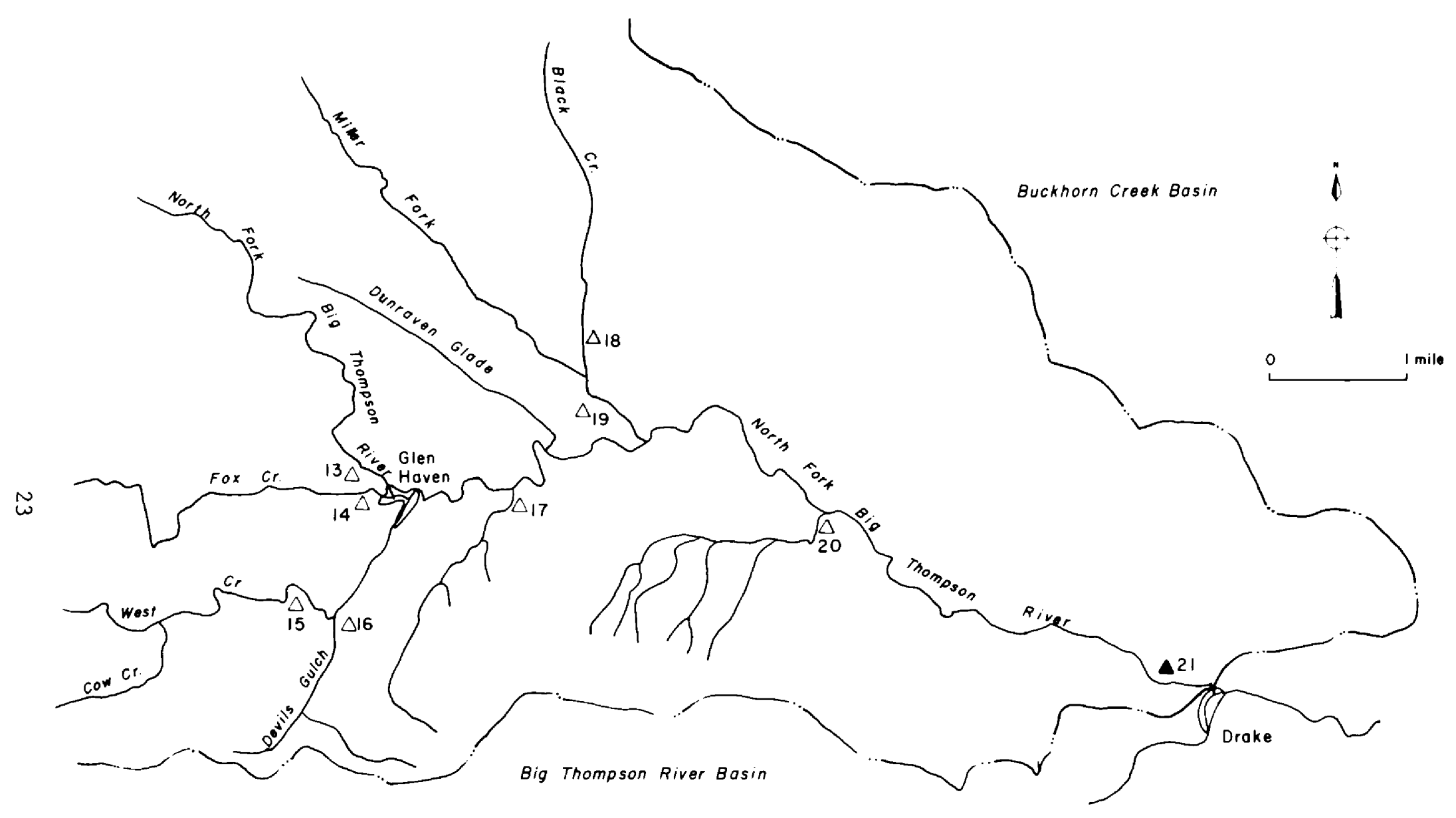

- Stream Gaging Station

$\triangle$ Peok Dischorge Determination Site

FIGURE 12 Discharge Sites on the North Fork Big Thompson River for the 31 July 1976 Flood 


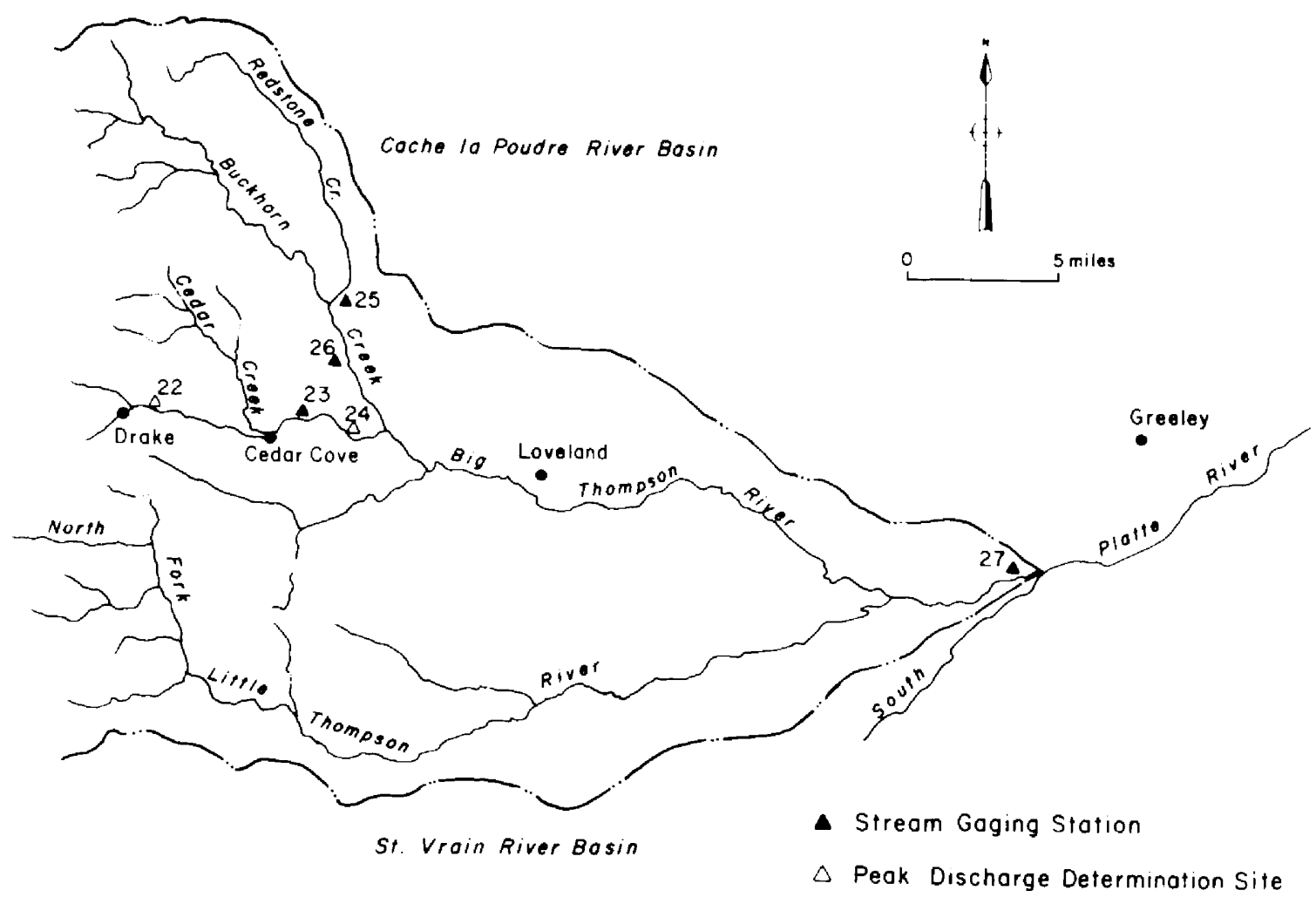

FIGURE 13 Discharge Sites on the Big Thompson River below Drake for the 31 July 1976 Flood

record for streams draining less than 4 square miles. Other major streams such as Noels Draw (site 9), Rabbit Gulch (site 10), Long Gulch (site 11), and an unnamed tributary (site 7) had extremely large rates of runoff. True Gulch near Waltonia appeared to be the limit of flooding to the east. Residents reported that peak stages occurred at Glen Comfort at $2000 \mathrm{MDT}$ and at Waltonia at $2030 \mathrm{MDT}$.

Little flod producing rain fell in the reach from Waltonia to Drake. Upstream of Drake (site 12) the peak discharge on the Big Thompson river was estimated to be $28,200 \mathrm{cfs}$ at $2100 \mathrm{MDT}$.

\section{North Fork Big Thompson River: Above Drake}

Heavy rainfall, centered slightly east of Glen Haven, produced severe flooding on the North Fork and its tributaries (Figure 12 shows this area). The severe flooding began at $2100 \mathrm{MDT}$ when heavy rainfall shifted northward from the region around Glen Comfort. South bank tributaries east of Glen Haven and directly north of Glen Comfort were the hardest hit. An unnamed tributary (site 17), with its mouth near the Glen Haven picnic ground, had a peak discharge of 9,670 cfs from 1.38 square miles--a discharge rate second only to Dark Gulch. Around Glen Haven, West Creek (site 15) had a peak discharge of 2,320 cfs, and Devils Gulch (site 16), a south bank tributary of West Creek, had a peak 
discharge of 2,810 cfs. Much of the flood damage to Glen Haven was caused by flood water from the West Creek basin. The North Fork and Fox Creek experienced only minor flooding. The area of high runoff extended from 2 miles west of Glen Haven to about 3 miles west of Drake. Tributaries north of the main stem experienced only minor flooding from this rainfall burst. A second burst at about 2300 MDT produced similar rises in stream leve1s. Particulary hard hit was Black Creek (site 18) which had a peak discharge of $1,790 \mathrm{cfs}$ at 2300 MDT.

At Drake, a peak discharge of $8,710 \mathrm{cfs}$ at $2140 \mathrm{MDT}$ was recorded for the North Fork by the stream gage operated by the Colorado State Engineers office. The gage operated satisfactorily until about 2300 MDT when sediment deposits covered the intakes. The second peak which occurred about $2300 \mathrm{MDT}$ around Glen Haven was not recorded.

\section{Big Thompson River: Drake to Mouth}

In general, flooding along the reach from Drake to the mouth was produced primarily by runoff from upstream areas (Figure 13 shows this area).

At Drake, flow from the North Fork combined with the Big Thompson. Fortunately, during the $31 \mathrm{July}$ flood, the peaks from the two streams did not coincide. If this had happened, flooding downstream could have been much worse. The Big Thompson peaked above Drake at 28,200 cfs at $2100 \mathrm{MDT}$, at which time $4,500 \mathrm{cfs}$ was discharging from the North Fork. The peak discharge was $30,100 \mathrm{cfs}$, measured about 0.4 miles east of Drake shortly after 2100 MDT.

The flood wave moved through the $8 \mathrm{mile}$ reach between Drake and Glen Comfort in about 25 minutes for an average rate of $19 \mathrm{mph}$. Because of little overbank storage, the flood peak was not attenuated as it moved downstream. At the mouth of the canyon, the flood crest was $31,200 \mathrm{cfs}$ at $2140 \mathrm{MDT}$. During this sharp rise, the gaging station at the canyon's mouth was destroyed. As a result, the peak discharge was estimated from high water marks. The gage, however, provided a good estimation of the timing of the flood peak. This peak discharge of $31,200 \mathrm{cfs}$ is almost four times greater than the previous recorded maximum discharge of $8,000 \mathrm{cfs}$.

Downstream from the canyon's mouth the valley greatly widens, and overbank storage began to attenuate the flood wave. At Green Ridge Glade, 2 miles below the canyon mouth, the peak discharge was reduced to 27,000 cfs. Further downstream ( 35 miles), the Big Thompson peaked at its mouth near LaSalle on 1 August at 2,470 cfs at 2235 MDT.

\section{Discharge Frequency}

Frequency discharges were computed at several of the discharge determination sites so that the return period could be estimated. Table 3 is a summary of these values. In general, this information was derived using the following analysis: (1) Log Pearson III statistical analysis, (2) Storm Water Management Model--a hydrologic model which, when combined with frequency rainfall, was used to estimate flood discharges, and (3) regression equations relating basin parameters to frequency discharges. 
TABLE 3

Flow Frequency Data at Selected Discharge Sites in Big Thompson Canyon

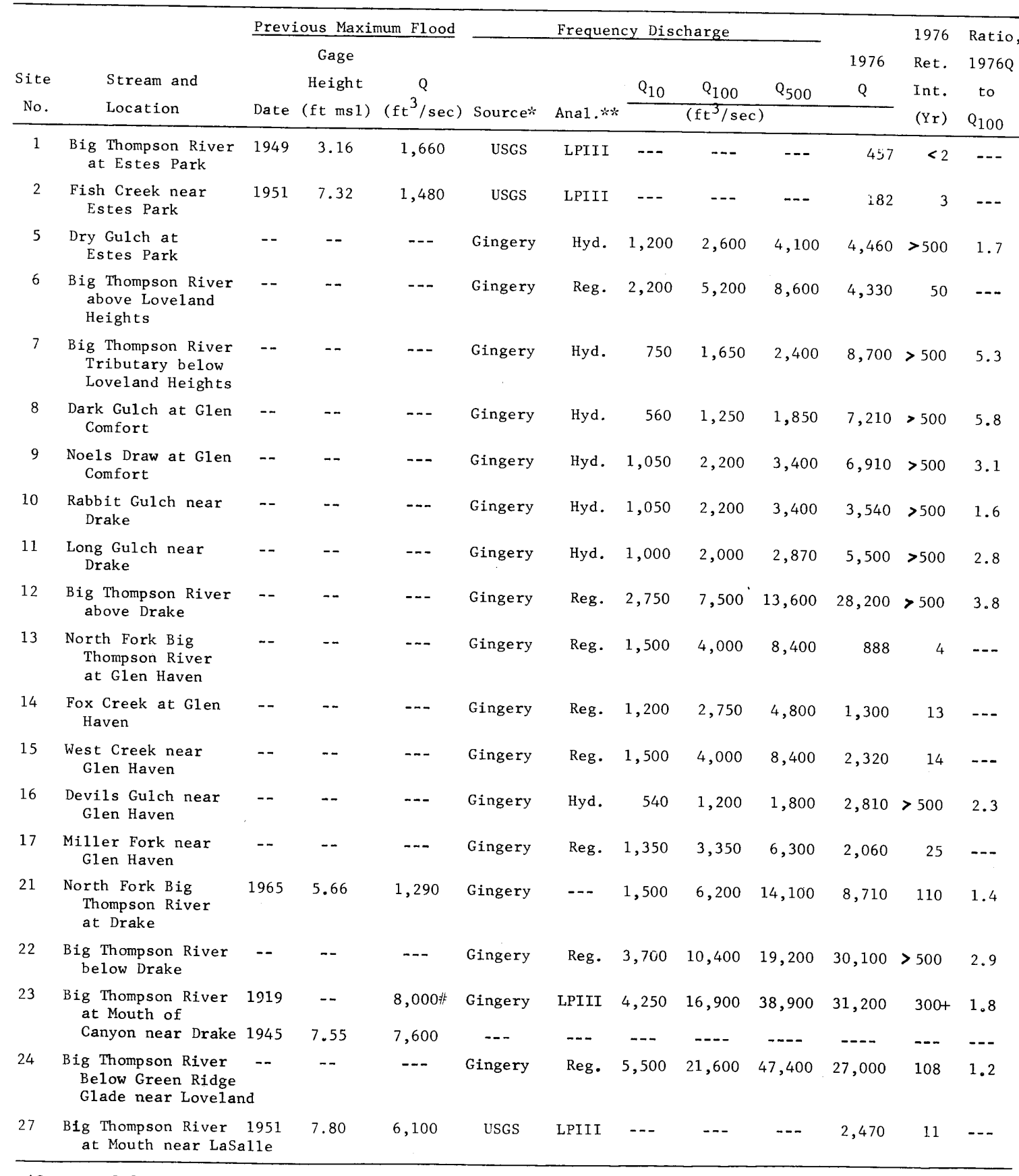

*Source of frequency information: USGS (McCain 1977) and Gingery and Associates, Inc. (1976).

* Type of analysis used to develop discharge probabilities.

Gingery and Associates:

1) LPIII--Log Pearson III

2) Hyd.--Hydrologic Model combined with frequency rainfall

3) Reg.--Regression relationship between drainage area, slope, and frequency discharge.

USGS: Log Pearson III

非Estimated 
Because these methods are all based on statistical analysis of historic rainfall and discharge data, the computed return periods may be higher than the actual values. Historic records are relatively short (good records for about 50 years), and generally do not include large, rare events. Therefore, the 1976 flood does not fit in with other data and must be considered a high outlier.

The discharge return periods associated with the 31 July 1976 flood decreased with an increased drainage area. This is a common occurrence where the flood producing rainfall is centered over a small drainage area in relation to the total size of the basin. In the area of heaviest rainfall, the return period normally exceeds 500 years and probably was within the range of several thousand years. Downstream at the mouth of the canyon, the return period was slightly greater than 300 years. Still further downstream at its mouth near LaSalle, the attenuated flood wave had a return period of only 11 years.

\section{FLUVIAL GEOMORPHOLOGY}

A geomorphic process is one in which landforms are changed by the forces of nature. Landslides, rockfalls, erosion, and deposition are all examples of geomorphic processes. A fluvial geomorphic process is one in which landforms are changed by the action of water. This process includes erosion and deposition by stream flow, and the erosion of soil by materials of overland flow (sheet erosion). Fluvial processes generally occur slowly and almost undetected when associated with daily stream flow. However, during rainfall or periods of high runoff, the processes accelerate rapidly. Furthermore, during spectacular events similar to the Big Thompson flood, fluvial transport can take on awesome proportions, eroding earth fill structures such as roadways and burying structures under debris. Figure 14 shows materials deposited by the Big Thompson river upstream of Drake, Colorado.

\section{Fluvial Processes}

Sheet erosion results from the suspension of fine surface materials by overland flow. Sheet erosion most commonly occurs on the gentle to moderate (5 to $15 \%$ ) slopes where rainfall is so intense that the infiltration capability of the soil is exceeded. Poorly developed soils of granitic origin (gruss) with little vegetative cover are subject to severe erosion. During the 1976 flood, sheet erosion removed almost 6 inches of gruss from intense rainfall areas (Doehring 1976). Soils that had developed from the weathering of metamorphic rocks were less susceptible to severe erosion. On steeper slopes sheet erosion was replaced by rill wash and Gullying. Figure 15 shows an area of sheet erosion along Dry Gulch near Estes Park.

Erosion and deposition along stream channels were primarily related to the velocity of flow. In general, higher velocities increase the 


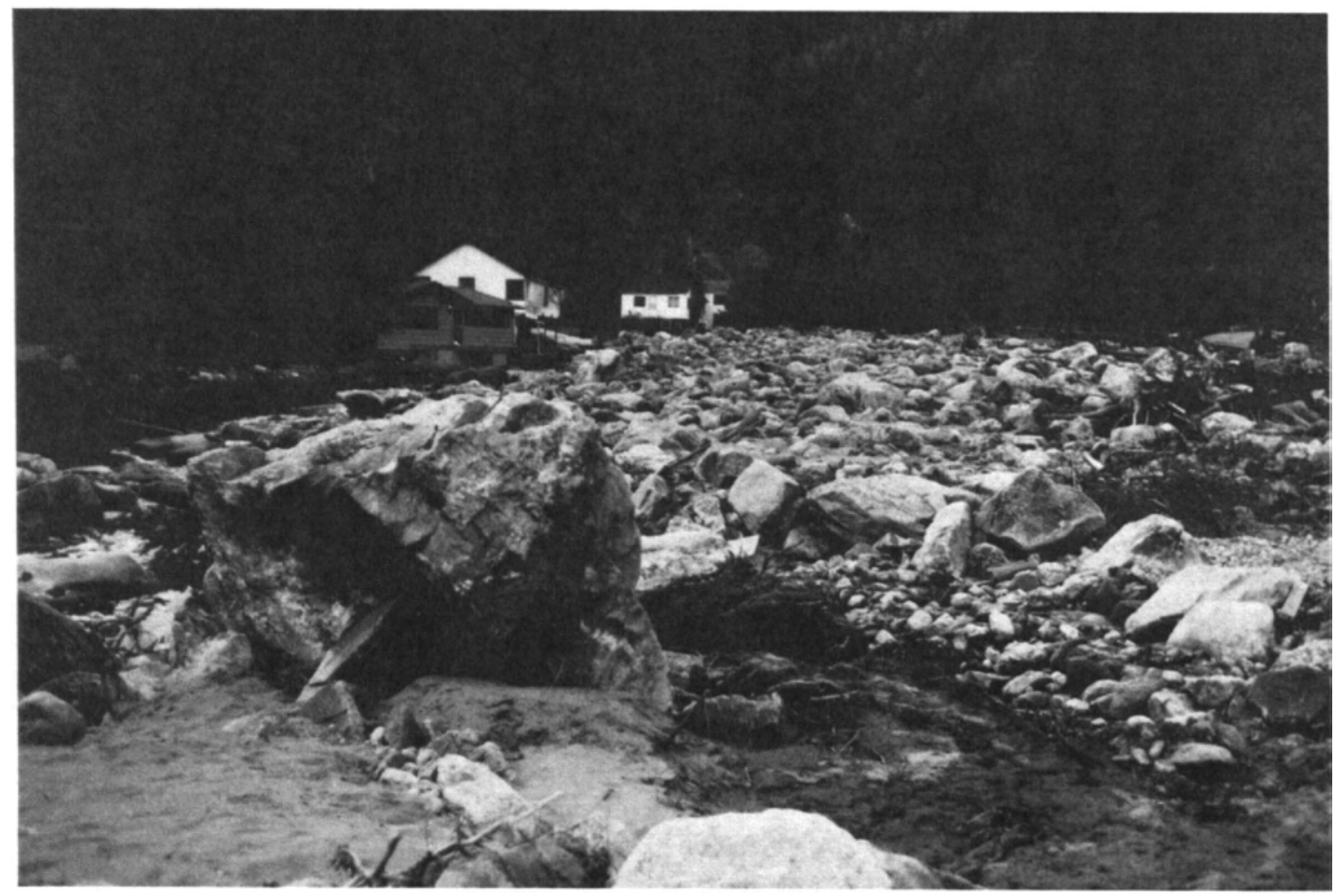

FIGURE 14 Boulder Deposit Upstream of Drake

stream's competence (maximum particle size moved by the stream) and its ability to erode and carry sediment. Velocity is related principally to the following factors: cross-sectional area, channel geometry, and stream gradient (slope). Decreasing the cross-sectional area and increasing the stream gradient both increase the velocity. Changes in channel geometry which reduce wetted perimeter also increase velocity. Local changes in velocity can also be significant when flow is concentrated on the outside of bends. In this case, the velocity along the inside is reduced causing deposition to occur, while the velocity on the outside is increased, causing scour (Figure 16).

Fluvial processes can also trigger mass wasting processes including landslides, rockfall, and debris slides. Streamflow around the outside of a bend can erode material at the toe, triggering landslides. Note how the landslide undermined the foundation materials of the small house. Debris slides and rock slides can result when sheet erosion removes the physical support holding rock and woody debris. This topic will be discussed further in the geotechnical section of this report.

\section{Summary of Sediment Transport}

Fluvial processes played an important part in the Big Thompson flood, causing a large portion of the property damage. In the area of heaviest rainfall along the North Fork and the Big Thompson above Drake, 


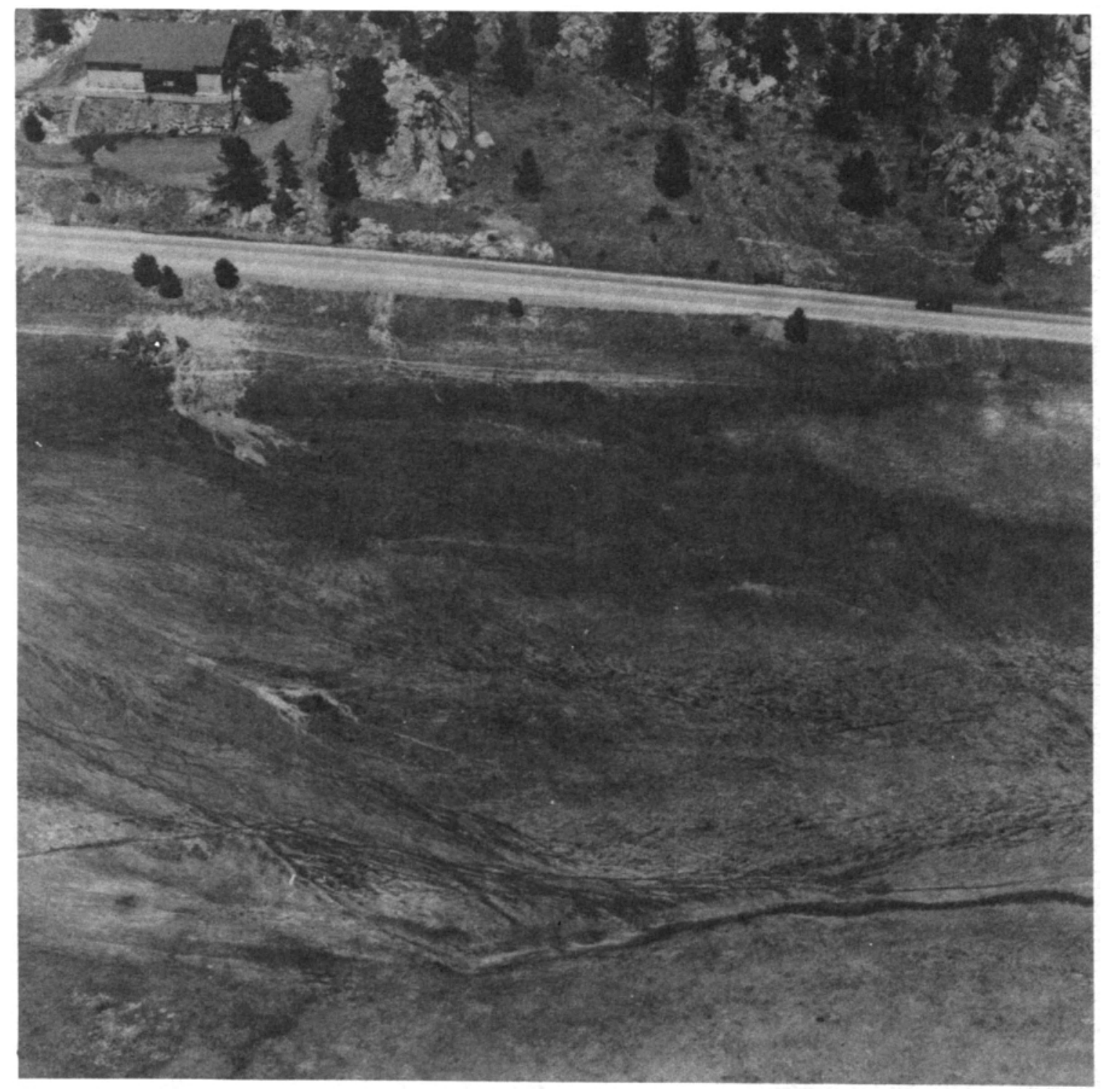

FIGURE 15 Sheet Erosion along Dry Gulch near Estes Park

severe sheet erosion supplied large amounts of material to the streams and gullies. The heavy runoff in the small, steep streams severely eroded channels to a depth of 6 or more feet, and sometimes down to bedrock. Along the main stem huge amounts of material were deposited downstream from the confluence of tributaries, where flow was insufficent to carry the mass of sediment. Lengths of the main stem with a steep gradient and/or a narrow channel experienced moderate to severe scour. Places where a valley widened experienced deposition of large amounts of material. Particularly hard hit were Drake and Cedar Grove. Channel changes were very few because of the narrow width of the valley. Below the mouth of the canyon where the valley widens out greatly, large 


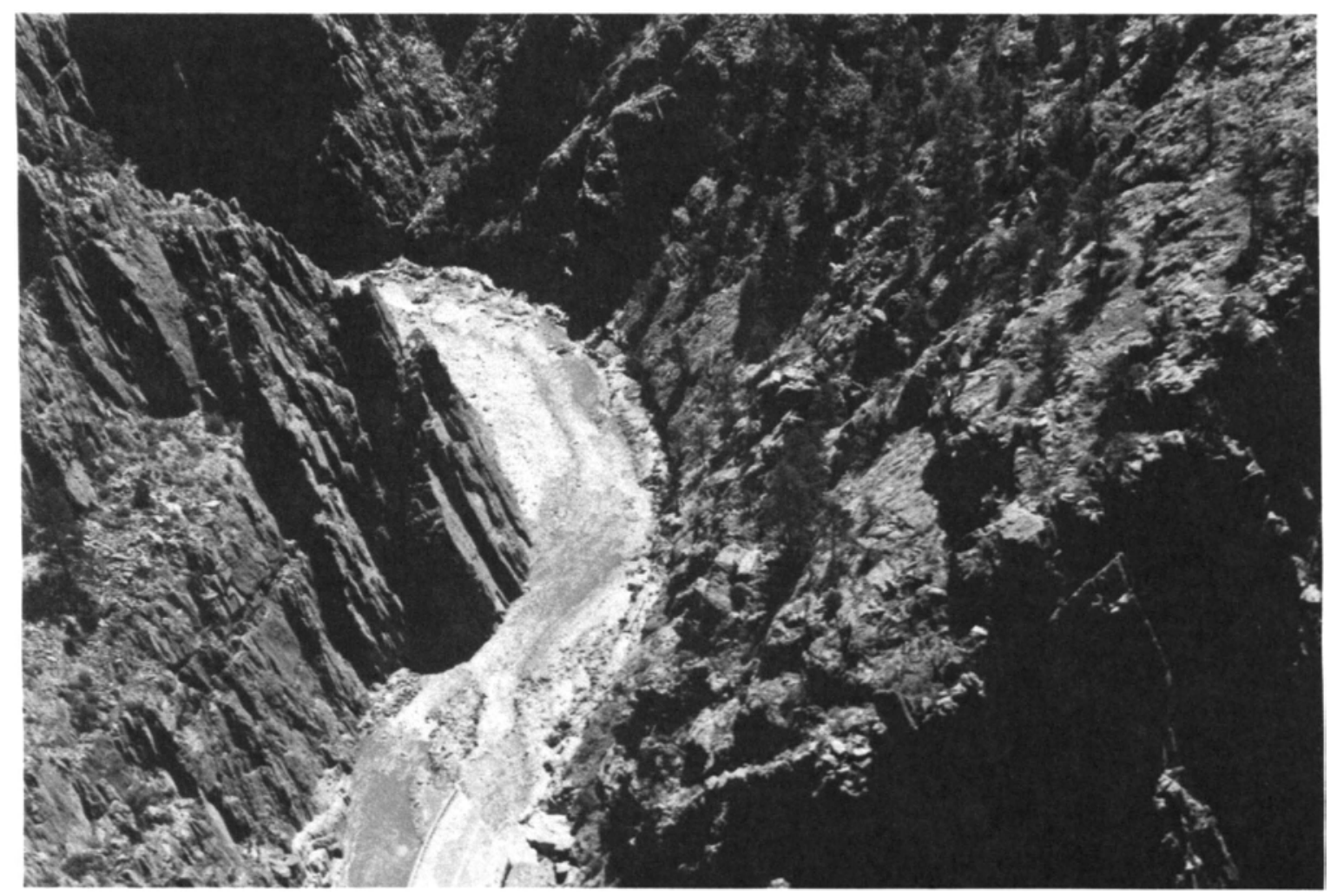

FIGURE 16 Erosion along Outside and Deposition along Inside of Stream Bed

amounts of materials were deposited in overbank areas. Figures 17, 18, and 19 summarize sediment transport during the flood. Figures 20 and 21 show the relationship between sediment transport, streambed slope, and valley width. In order to facilitate the discussion in the following sections, the streams are divided into reaches noted on Figures 20 and 21. Details on the velocity of the streams are presented in Table 2.

Big Thompson above Drake

BT-1:--Reach BT-1 is characterized by sheet erosion, severe scour along tributaries, and deposition along the main stem. This area received the most intense rainfall and had the largest area of sheet erosion in the northern part of the reach. Overland flow concentrated rapidly, causing large discharges and very high velocities in tributaries. The average slope of tributaries exceeded 450 feet per mile and the average velocities were greater than 20 feet per second. The high velocities eroded 6 to 10 feet of material and, in some cases, eroded the channel down to bedrock. Near the mouths of the tributaries where stream gradients decrease as flow enters the main stem, large amounts of materials were deposited in debris fans. Often these fans infringed on property and caused severe damage, This is particularly true near Glen Comfort where 


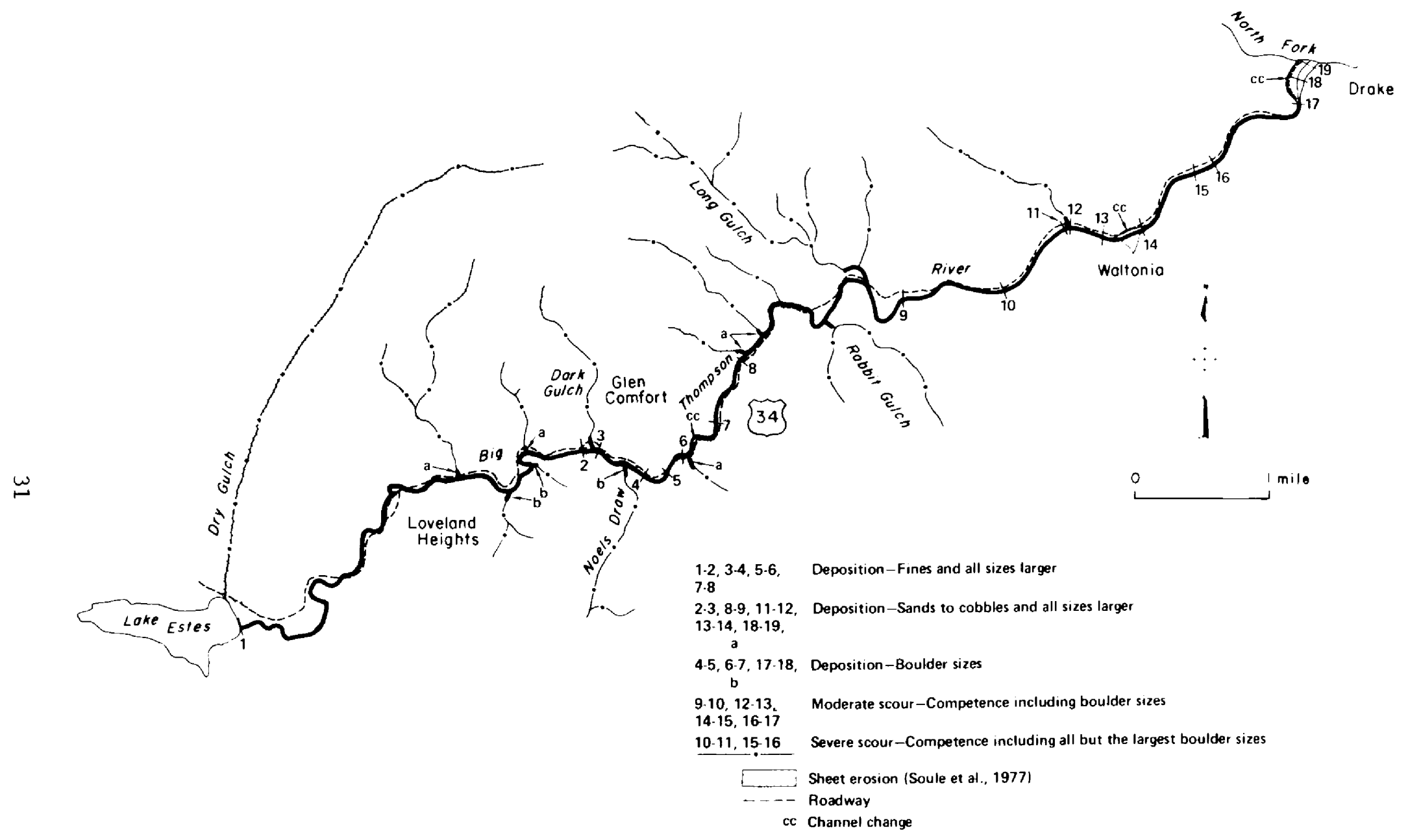

FIGURE 17 Sediment Transport along the Big Thompson River above Drake on 31 July 1976 


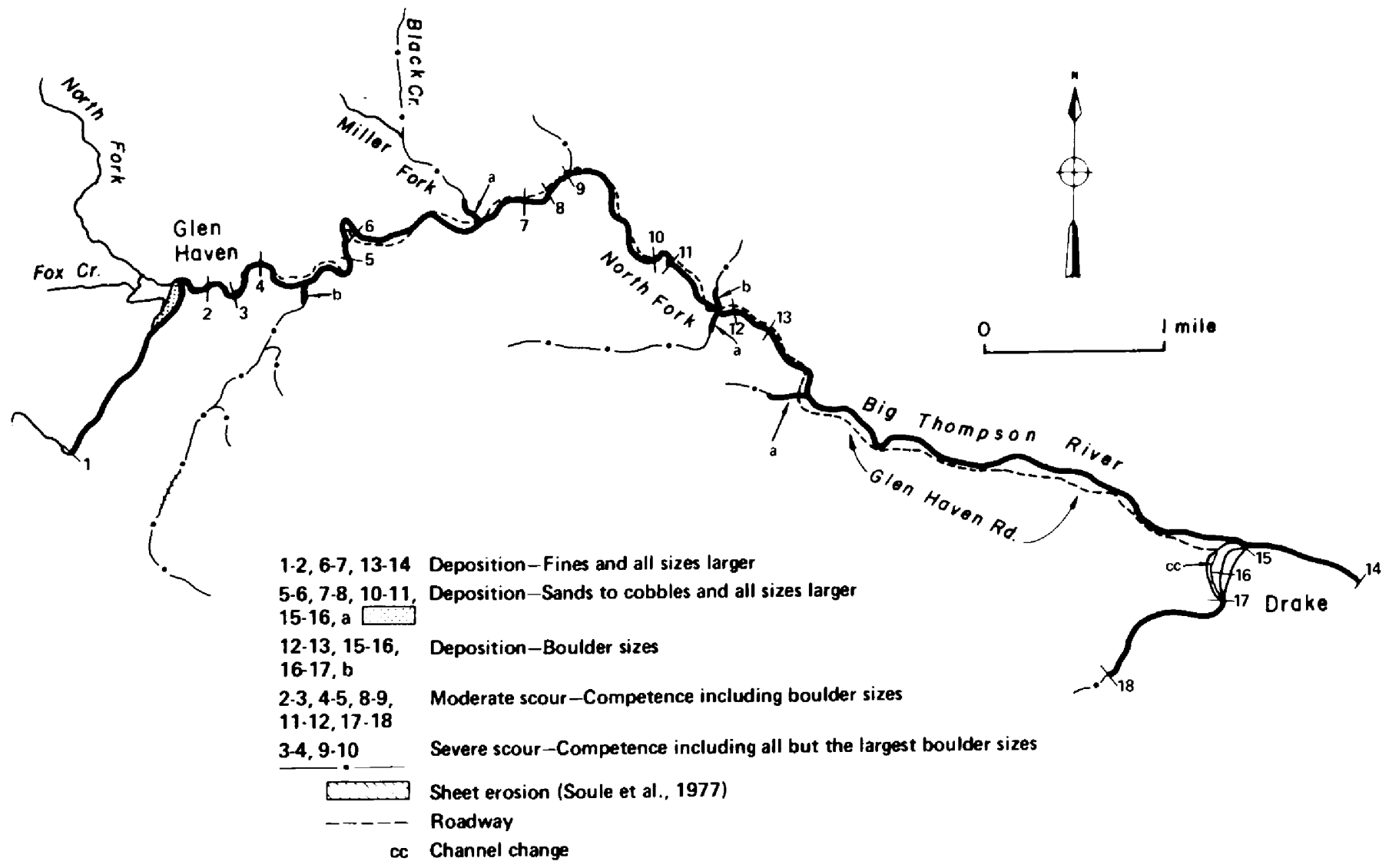

FIGURE 18 Sediment Transport along the North Fork Big Thompson River above Drake on 31 July 1976 


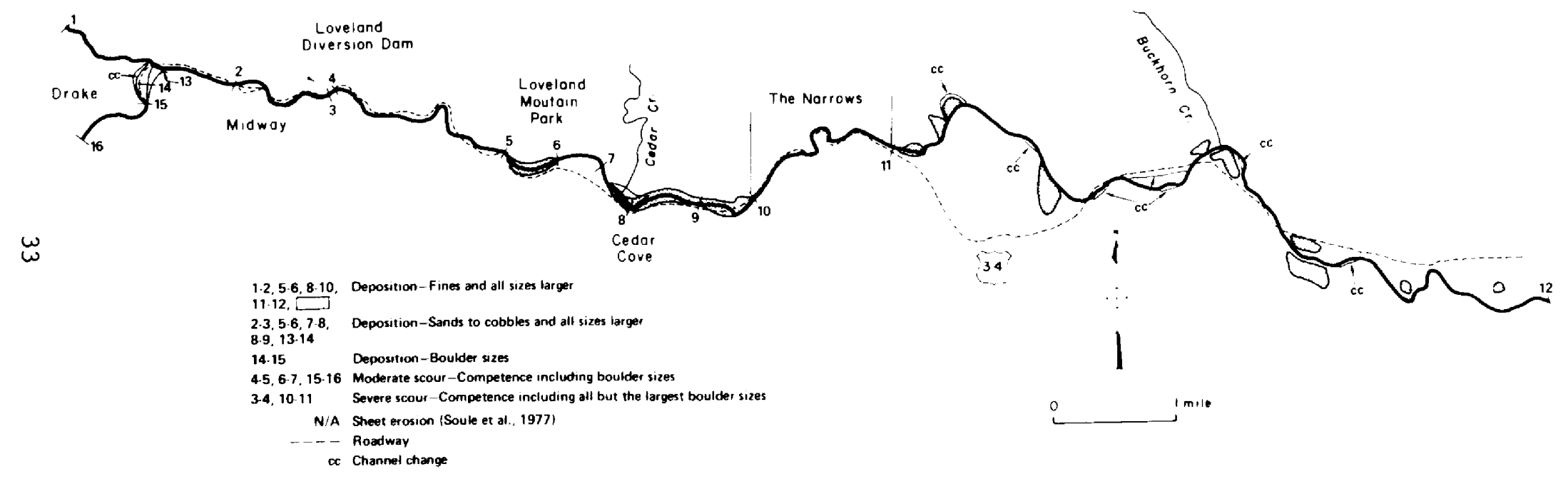

FIGURE 19 Sediment Transport along the Big Thompson River below Drake on 31 July 1976 


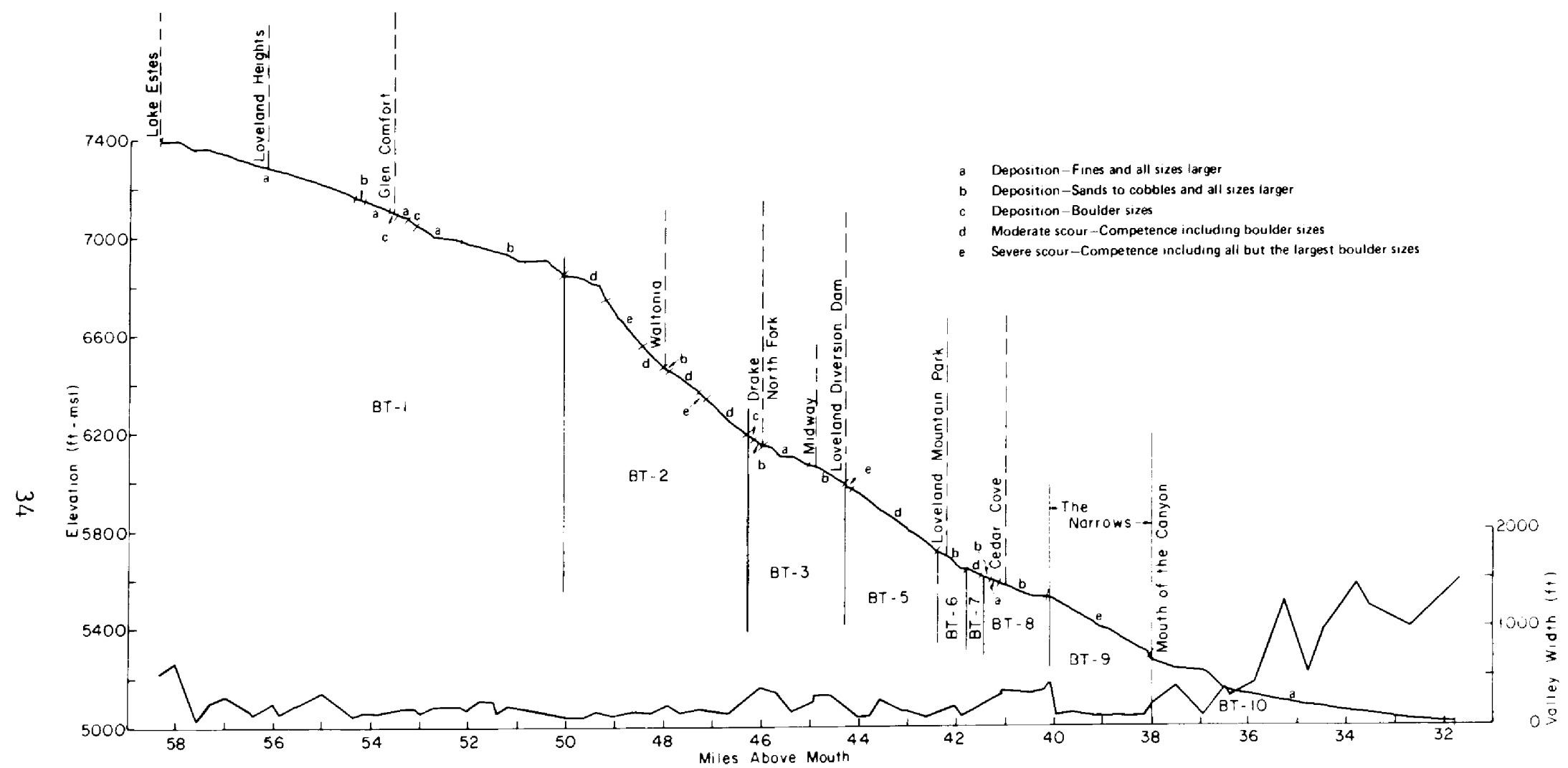

FIGURE 20 Sediment Transport vs. Stream-Bed Slope and Valley Width along the Big Thompson River 


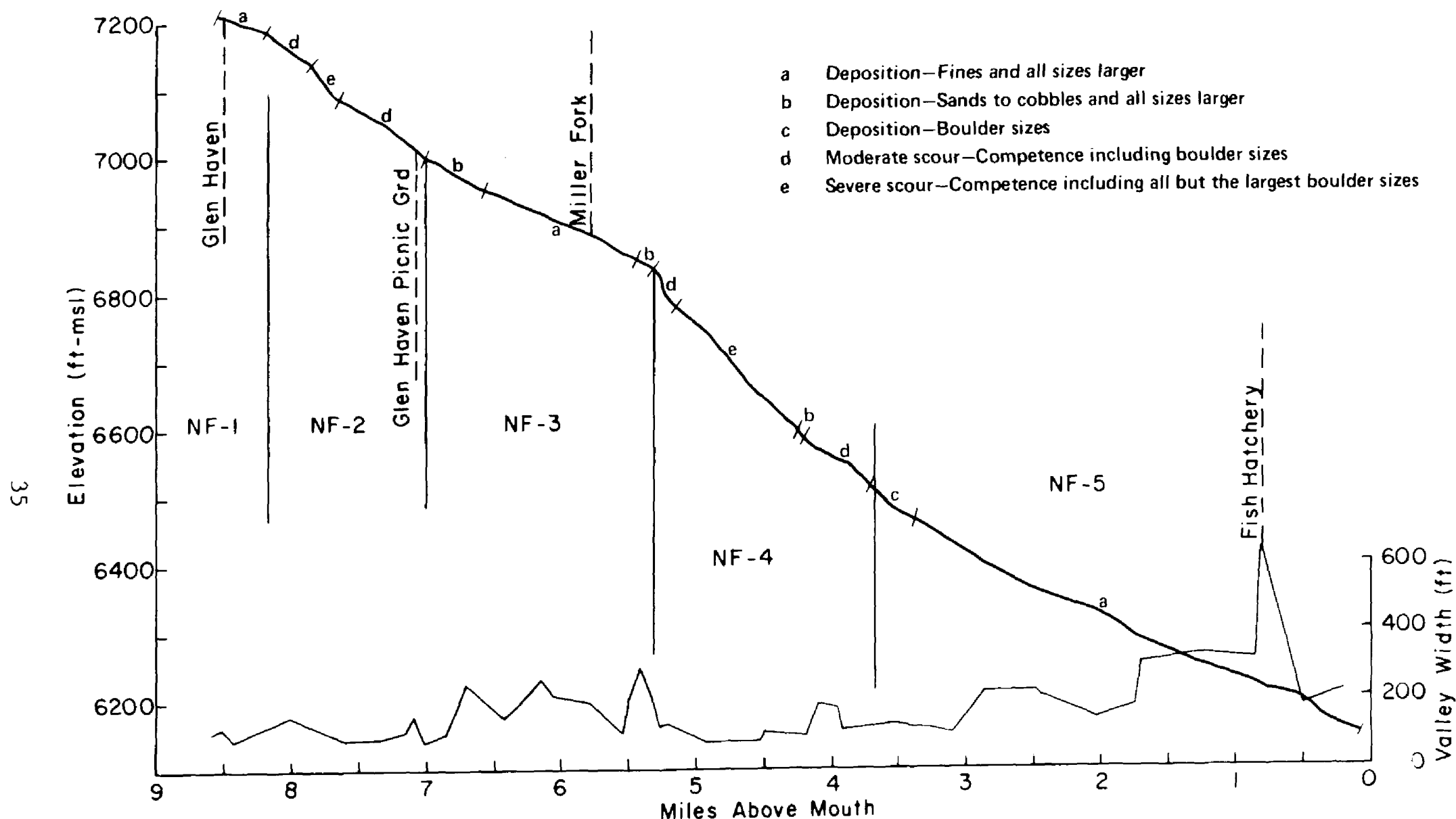

FIGURE 21 Sediment Transport vs. Stream-Bed Slope and Valley Width along the North Fork Big Thompson River 


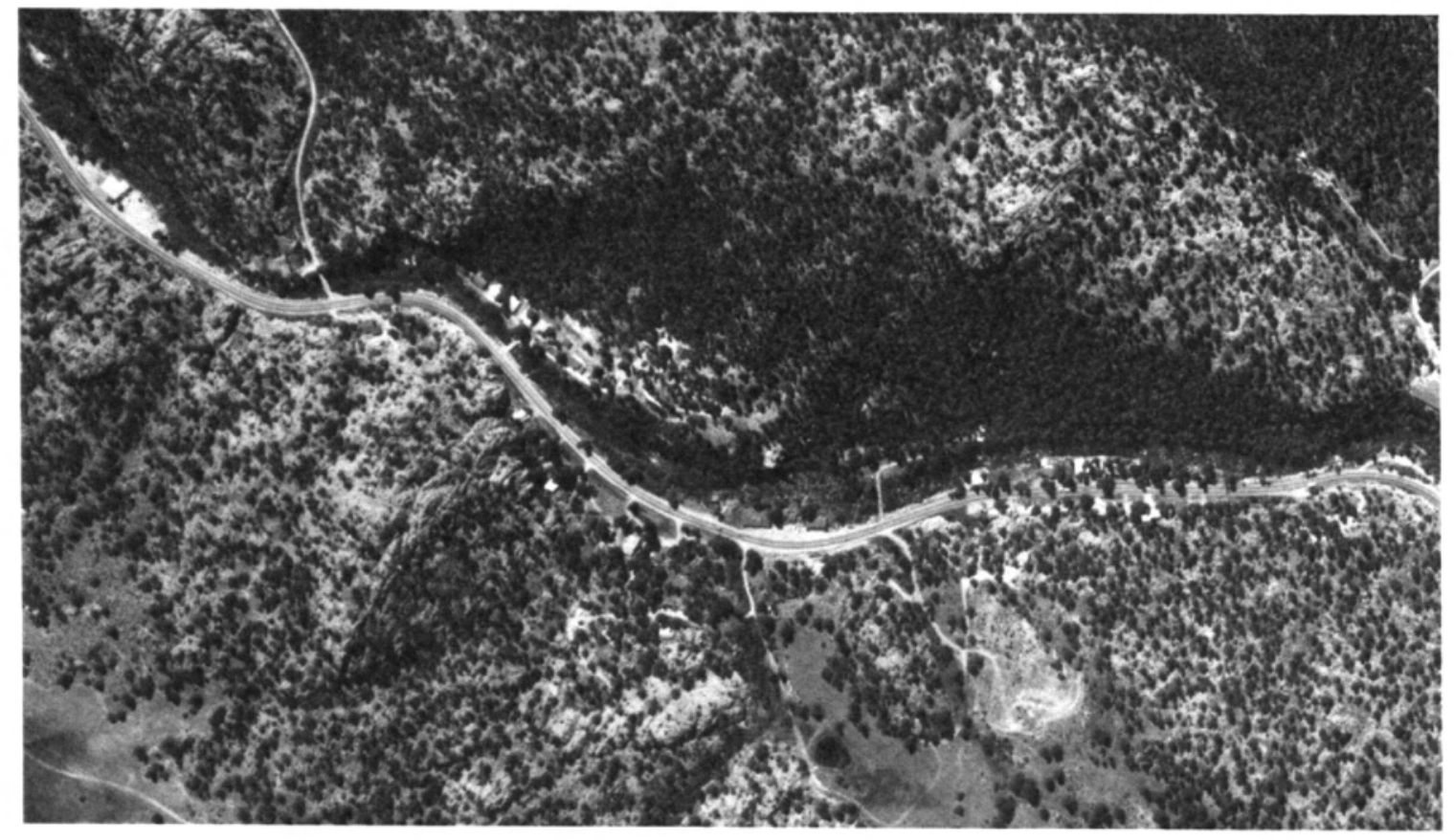

Before the Flood

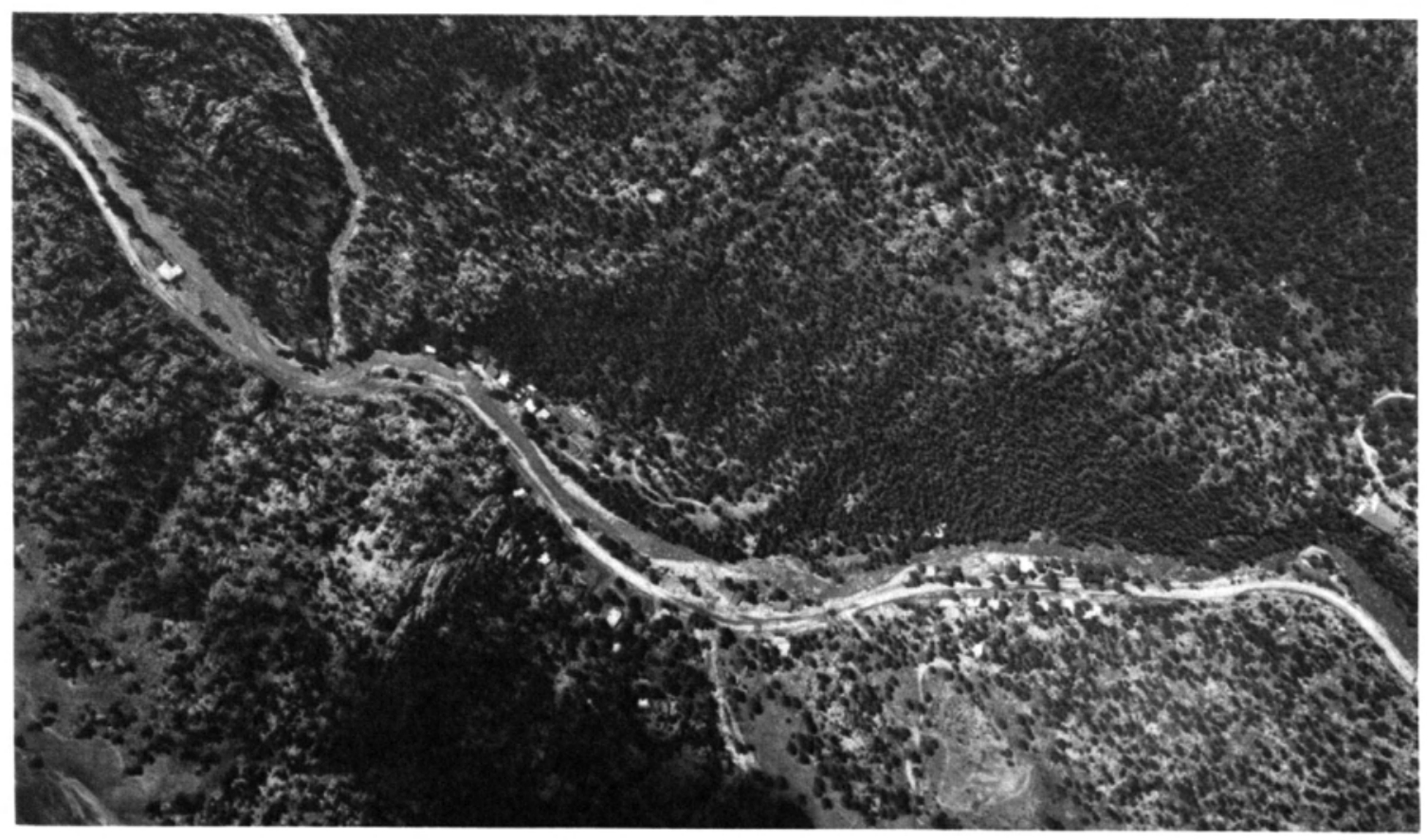

After the Flood

FIGURE 22 Small Tributaries Entering the Big Thompson River near Glen Comfort, before and after the Flood 
the debris from Dark Gulch covered part of the town. Figure 22 shows before and after aerial photographs of the area around Glen Comfort. Note the intense scour along Dark Gulch and the manner in which the debris fan covered the town.

Along the main stem, the flow could not support the heavy inflow of debris and sediment. The slope along this reach averaged about 70 feet per mile while the average valley width was 170 feet. As a result, large amounts of sediment of all sizes were deposited in the overbank areas and within the channel. The bed form of the channel was braided, indicating overloading. The probable stream competence was sands.

Further downstream, outside of the area of heaviest rainfall near the end of the reach, the width of the channel decreased. This caused an increase in velocity and a corresponding increase in stream competence to include gravels to small cobbles. Sands to cobble sizes were deposited in the overbank areas while the fine materials were still deposited within the channel. The increased stream competence could have been caused by two factors: the narrowing of the channe1, or a reduction in overloading caused by less tributary flow.

BT-2:--Reach BT-2 was characterized by moderate to intense scour caused by a much steeper gradient and a narrow channel. Slope along this reach averaged 160 feet per mile, while the average valley width was about 150 feet. United States Highway 34 was severely damaged in this area. The area denoted as severe scour in Figures 17 and 20 above Waltonia was probably one of the most severe along the Big Thompson River. Here, the slope exceeded 270 feet per mile, and the valley width was reduced to about 100 to 150 feet. Since stream competence was difficult to estimate, it can be said that only the largest boulders were not moved. Figure 23 shows the area before and after the flood.

Just upstream of Waltonia the valley widens to about 200 feet, resulting in a reduction of stream competence even though stream gradient changed little. Materials scoured from upstream overloaded flow and caused extensive deposition. Channel braiding can be seen immediately above Waltonia (Figure 24, after). Near Waltonia the original channel was clogged by deposited materials, forcing a shift in the channel to the north slope of the valley, eroding the highway.

Downstream toward Drake the valley narrowed, resulting in moderate to severe scour. Stream competence probably included boulder sizes. Figure 25 shows a length of this stream just above Drake. Note that the highway is completely gone. Just above Drake at site 12 , a discharge of 28,200 cfs and a velocity of $22 \mathrm{fps}$ was estimated, illustrating the predominantly high velocities along this reach.

\section{North Fork above Drake}

NF-1:--This reach is characterized by heavy deposition around Glen Haven. Much of this material came from Devils Gulch to the south, which showed signs of severe scour. Aerial photographs showed little activity from the North Fork, Fox Creek, or West Creek, west of Glen Haven. Figure 26 provides an idea of the depth of sediment which was deposited at Glen Haven. 


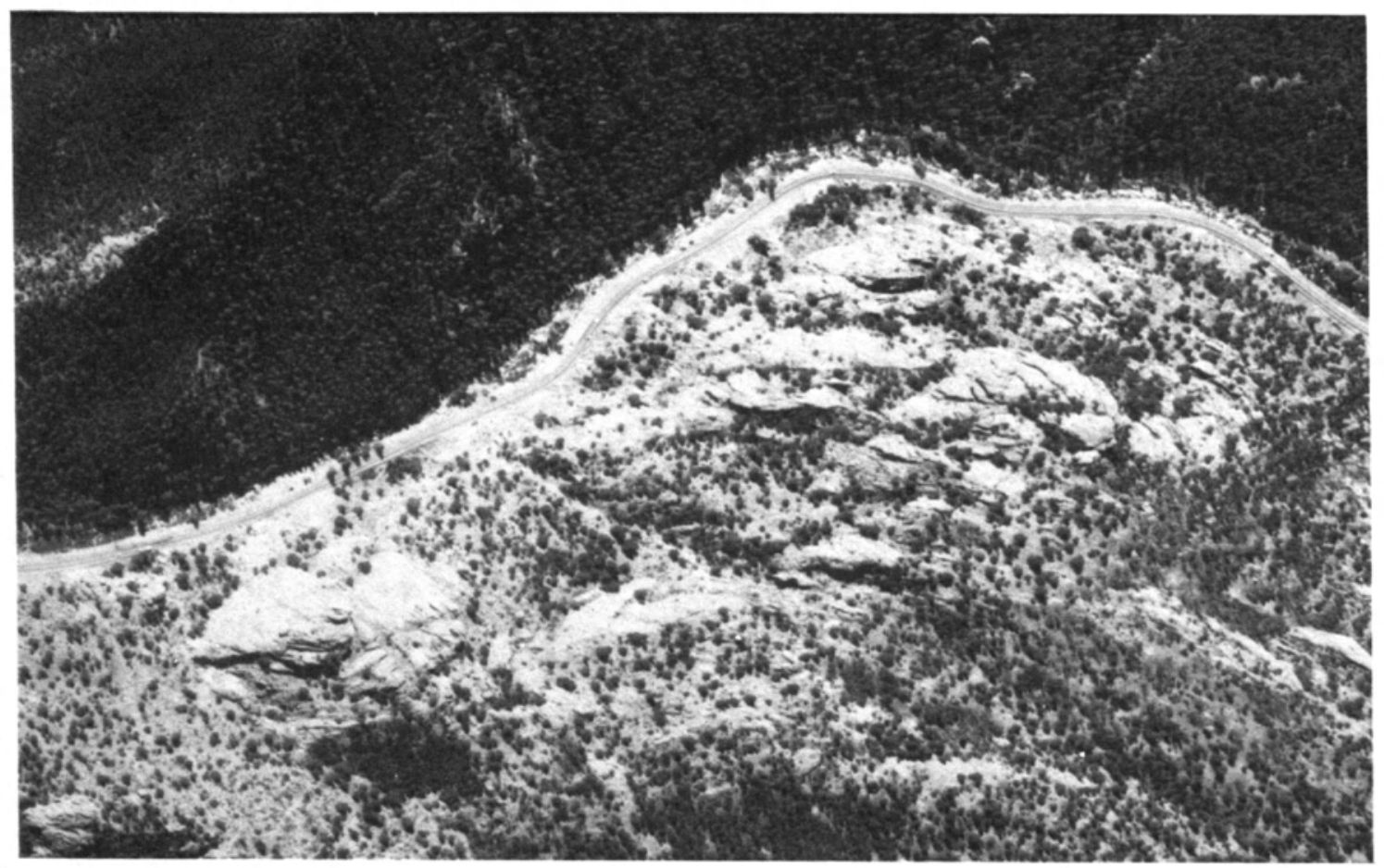

Before the Flood

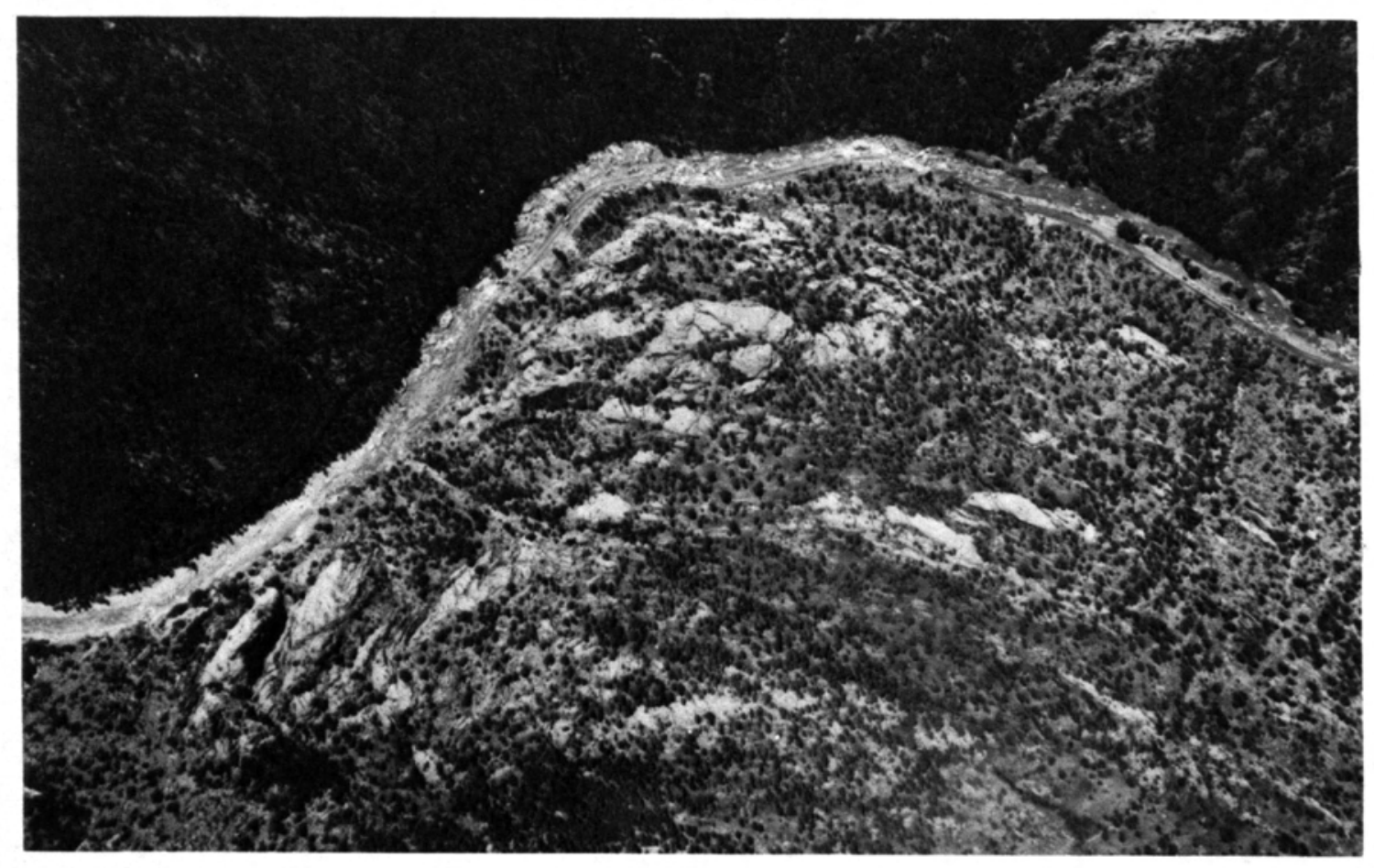

After the Flood

FIGURE 23 Severe Scour along the Big Thompson River above Waltonia 


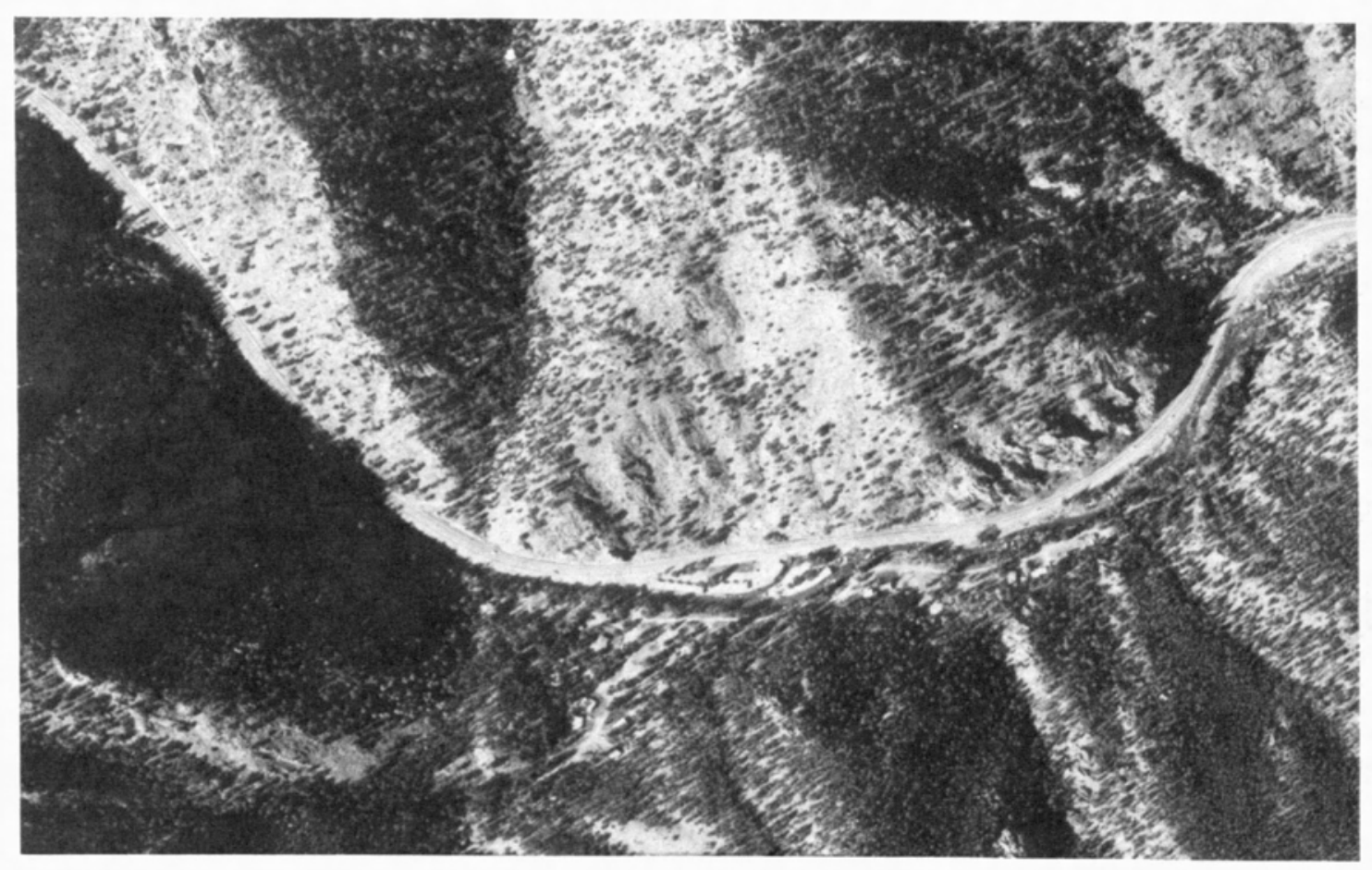

Before the Flood

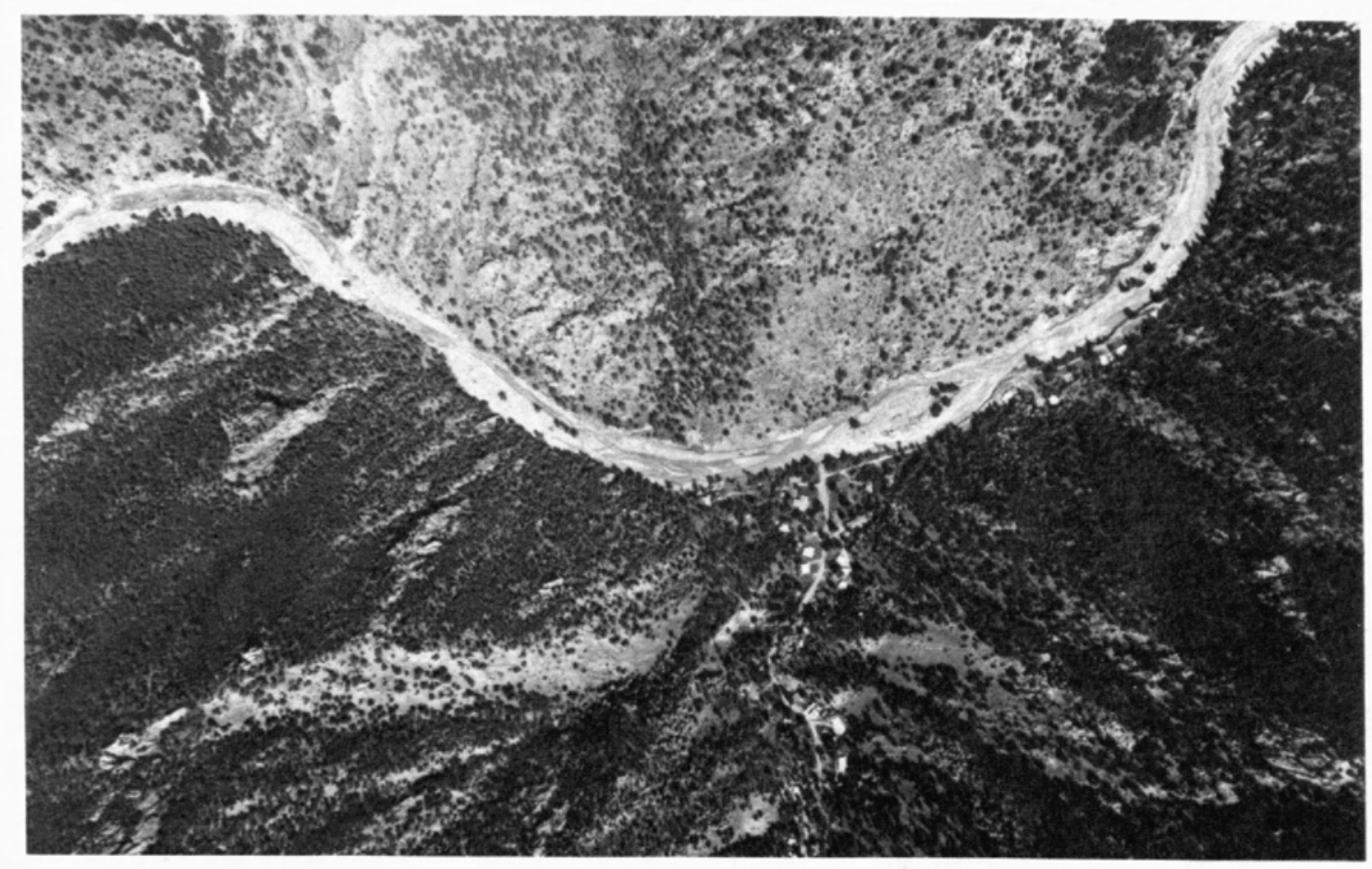

After the Flood

FIGURE 24 Waltonia Area 


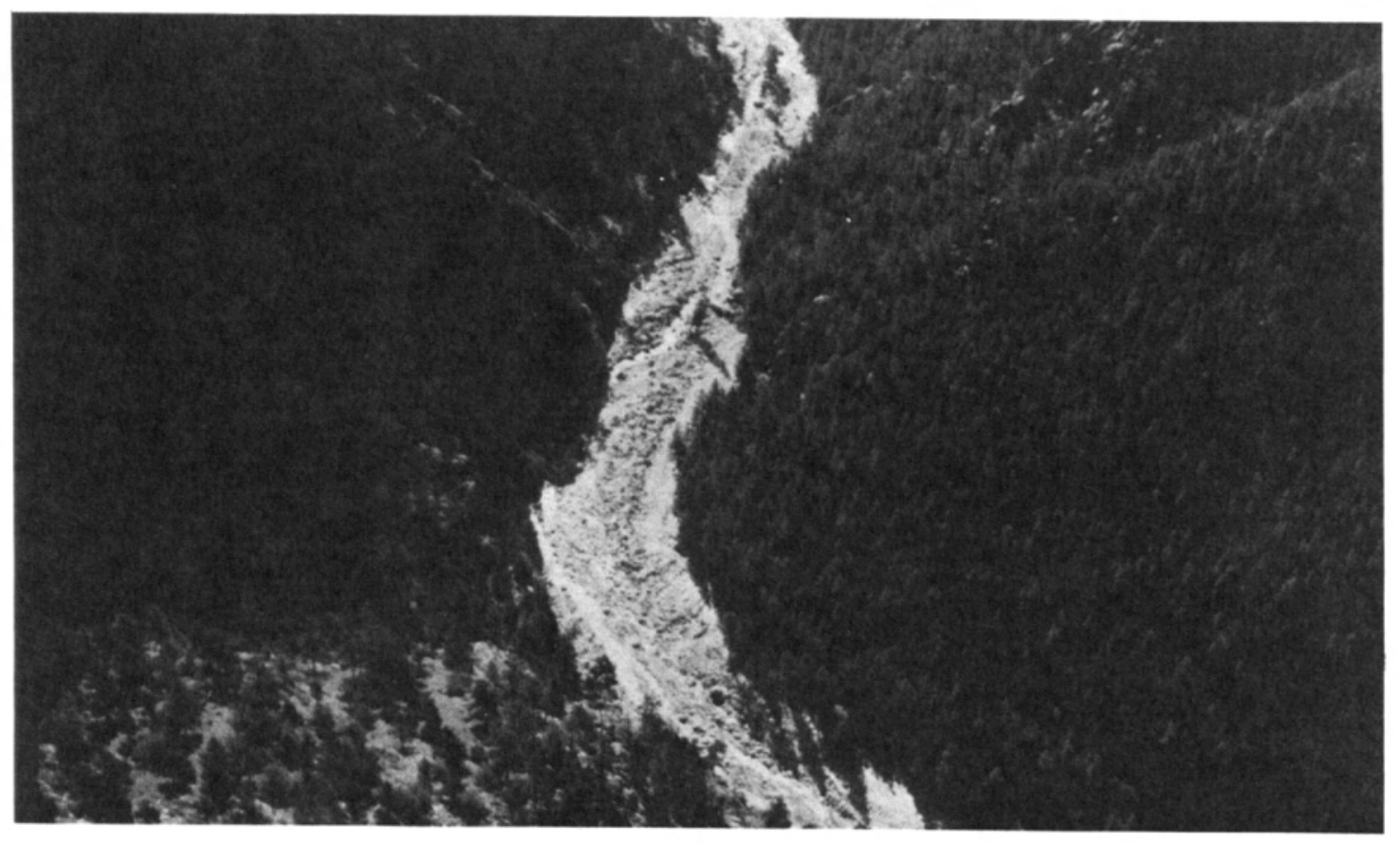

FIGURE 25 Scour on the Upstream Reach from Drake

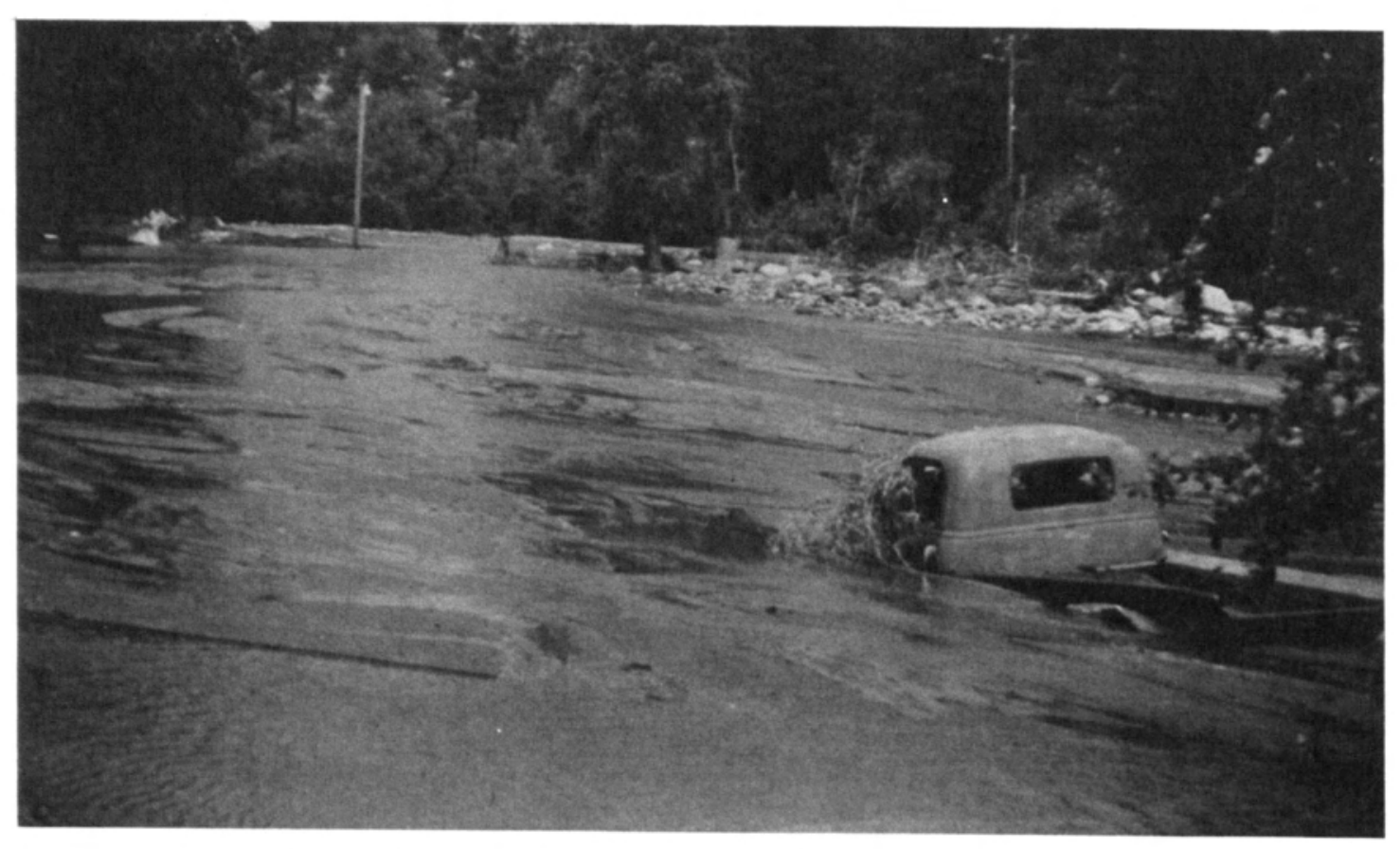

FIGURE 26 Sediment Deposited in the Glen Haven Area 
NF-2:--This reach is characterized by scour along the main stem and along its tributaries. Immediately below Glen Haven, the valley narrows to an average of about 100 feet in width, and the gradient increases to about 150 feet per mile. Stream competence in this reach included boulder sizes. An unnamed tributary (site 17) which enters from the south experienced severe scour and produced large amounts of sediment. A small bar was deposited immediately below its confluence, indicating some localized overloading. In general, the high velocities characteristic along this reach were able to transport the vast majority of materials. Glen Haven road which parallels the river along this reach was severely eroded.

NF-3:--Materials of all sizes were deposited along this reach. Slope decreases to about 90 feet per mile and the valley width varies from 100 to 300 feet. Stream competence was probably sands. In the upstream portion a transition zone exists where velocity decreases. In this zone, gradation varied from coarse to fine from upstream to downstream respectively.

NF-4:--Along this reach the gradient again increases to about 200 feet per mile, and the valley width decreases to about 100 feet. This reach experienced severe scour with stream competence including boulder sizes. Figure 27 shows a length of this reach. Note that the roadway which had paralleled the river was eroded away.

NF-5:--This reach was characterized by the deposition of materials of all sizes. Slope decreases to about 90 feet per mile and valley width varies from 100 to over 500 feet. Stream competence was probably sands

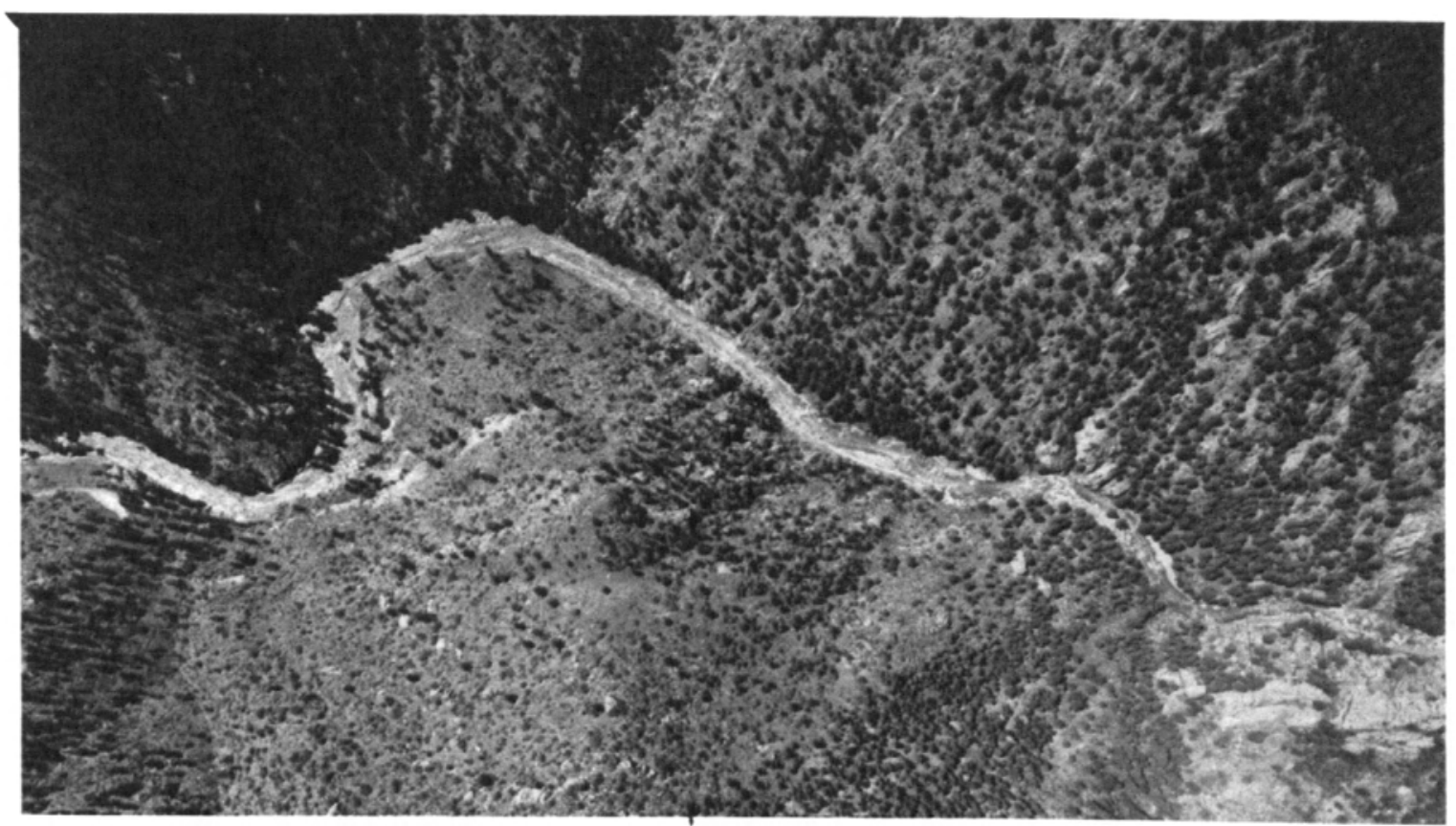

FIGURE 27 Scour along the North Fork 
or smaller sizes. The upstream end of the reach is marked by a large boulder field deposited as floodwaters from upstream slowed. Figure 28 shows a view of the stream near the fish hatchery above Drake. Notice the incredible amount of material deposited. At site 21 just above Drake, the North Fork crested at $8,710 \mathrm{cfs}$ with a velocity of $12 \mathrm{fps}$. This velocity was much lower than the relatively low velocities characteristic along this reach.

\section{Drake to Midway}

BT-3:--This reach is characterized by a widening in the valley and the deposition of large amounts of material. Valley width varies from about 400 feet near Drake to about 300 feet just upstream of Midway. As the Big Thompson river entered Drake from the southeast, it possessed very high velocities ( $22 \mathrm{fps}$ at site 12 ), and carried material up to boulder sizes. As the valley widened, velocity and stream competence were reduced by overbank storage, causing large amounts of material to be deposited. These materials clogged the main channel along the western slope of the valley, eroding U.S. Highway 34. The deposits varied in gradation with coarse materials deposited further upstream. Figure 29 shows Drake looking upstream along the Big Thompson river. Note the

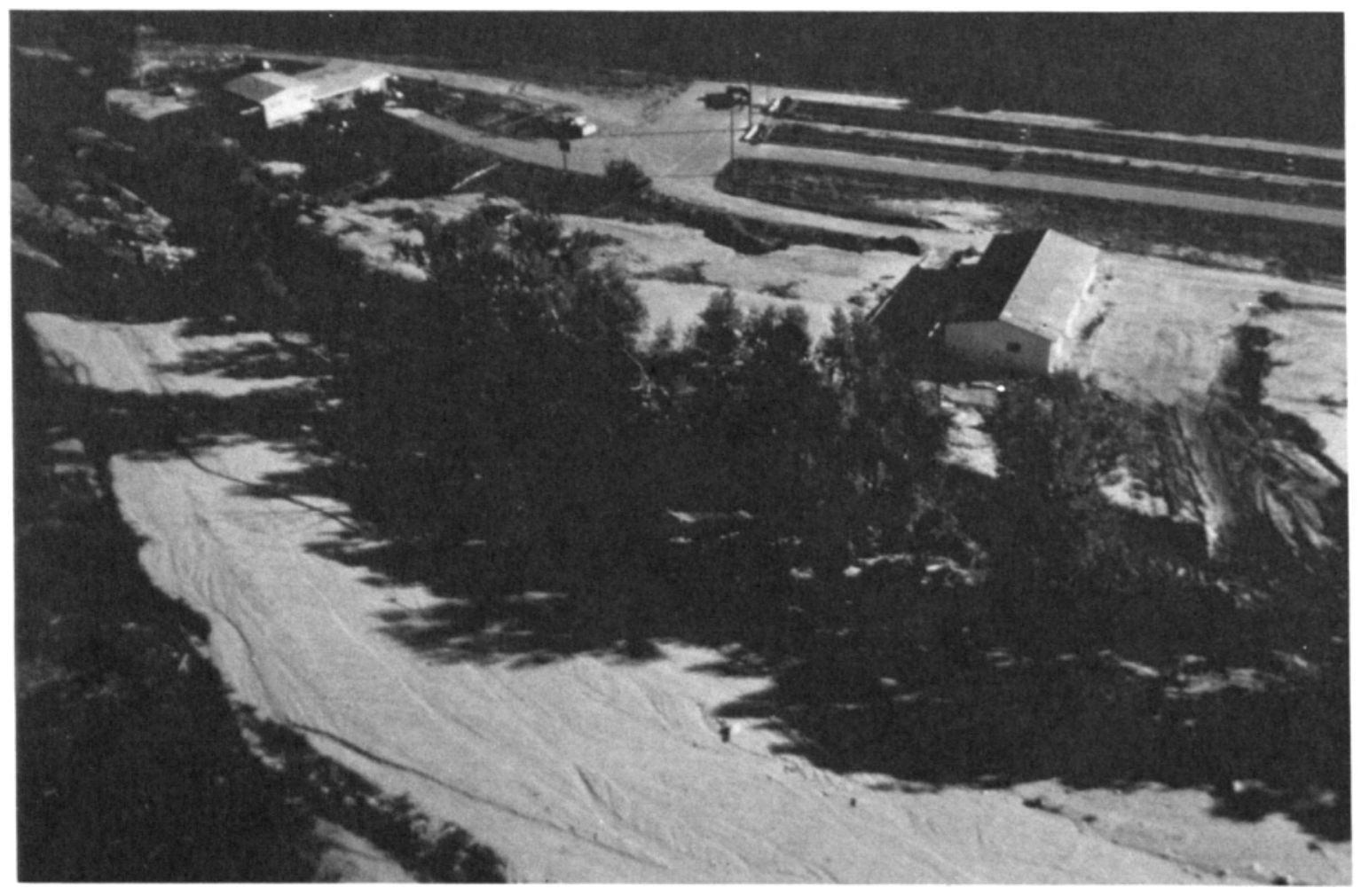

FIGURE 28 Deposits along the North Fork near the Fish Hatchery just Upstream from Drake 


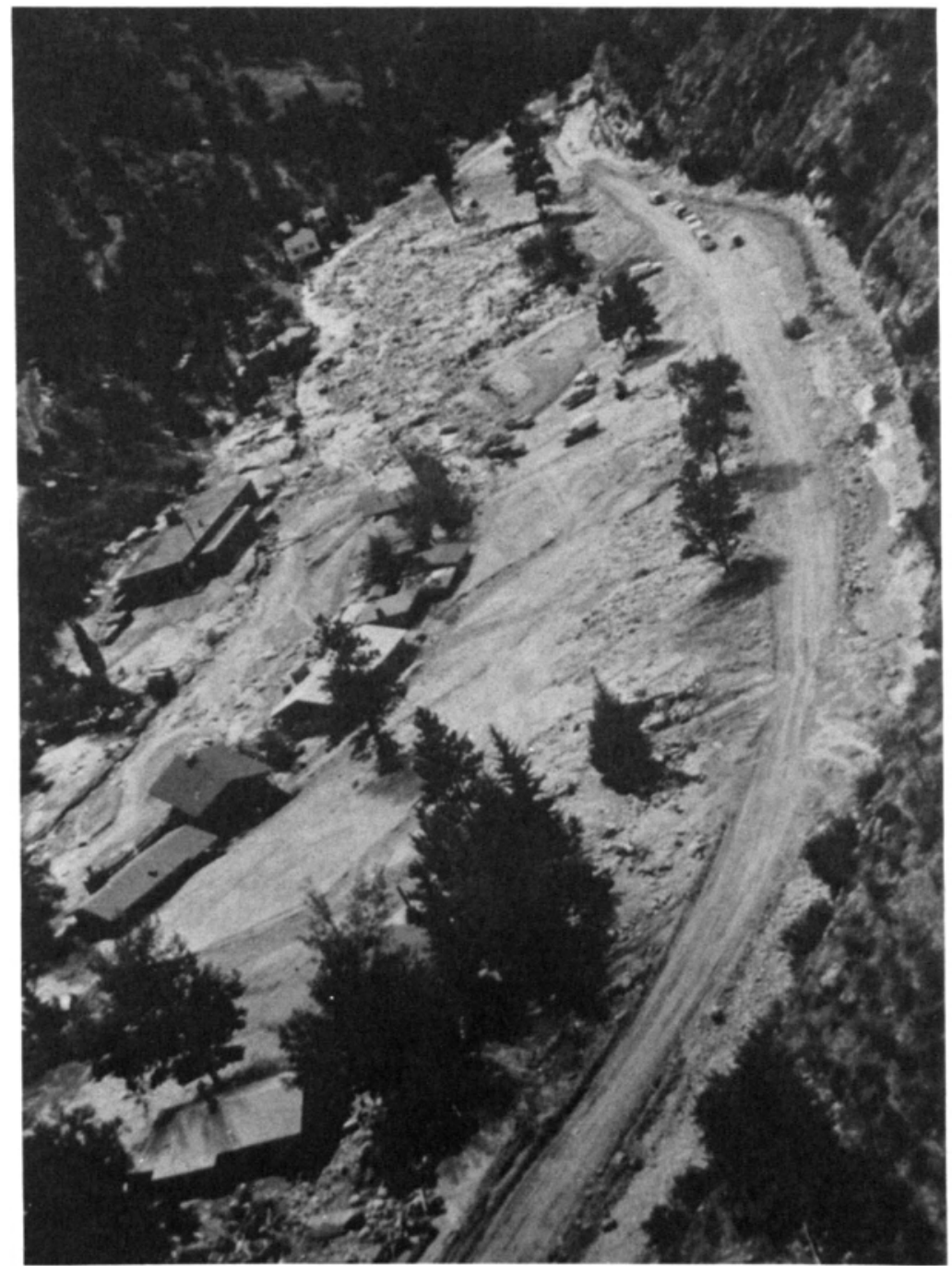

FIGURE 29 Grading of Materials Deposited by the Big Thompson River at Drake

change in gradation in the downstream direction. Figure 30 shows aerial photographs before and after the flood event. Ths changes are very marked. Below Drake the velocity of the Big Thompson river was estimated to be $16 \mathrm{fps}$ at site 22 , indicating a change in velocity caused by the widening of the channel.

The North Fork deposited large amounts of fine material near Drake as shown in Figure 31, a view looking northwestward, upstream along the North Fork. Note the difference in the gradation of the material laid down by the North Fork and the Big Thompson rivers.

From Drake to Midway, large deposits of fine materials were laid down. Most of the surface material probably came from the North Fork since no evidence of brown silty material existed along the Big Thompson river above the confluence. The materials were probably deposited after 


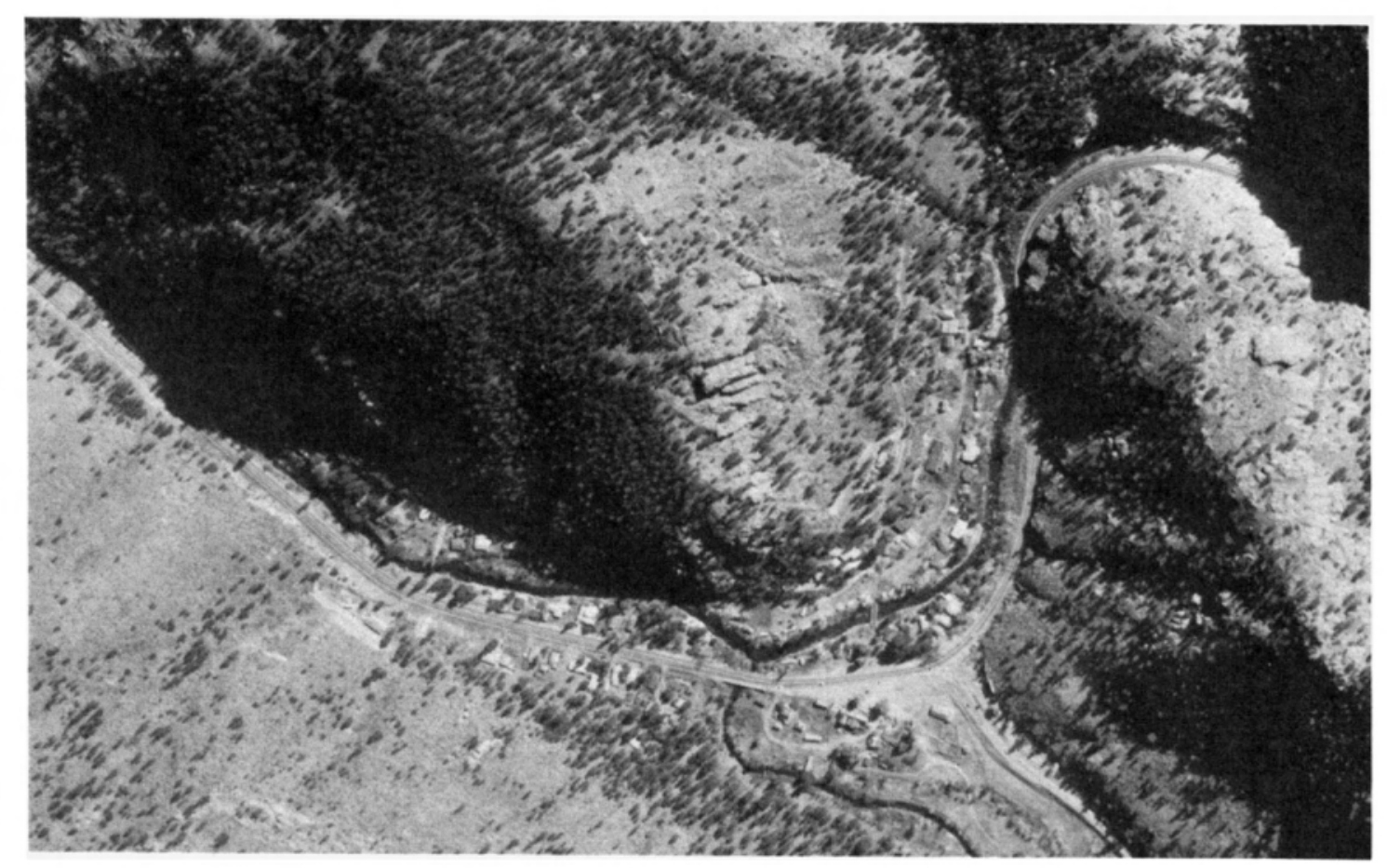

Before the Flood

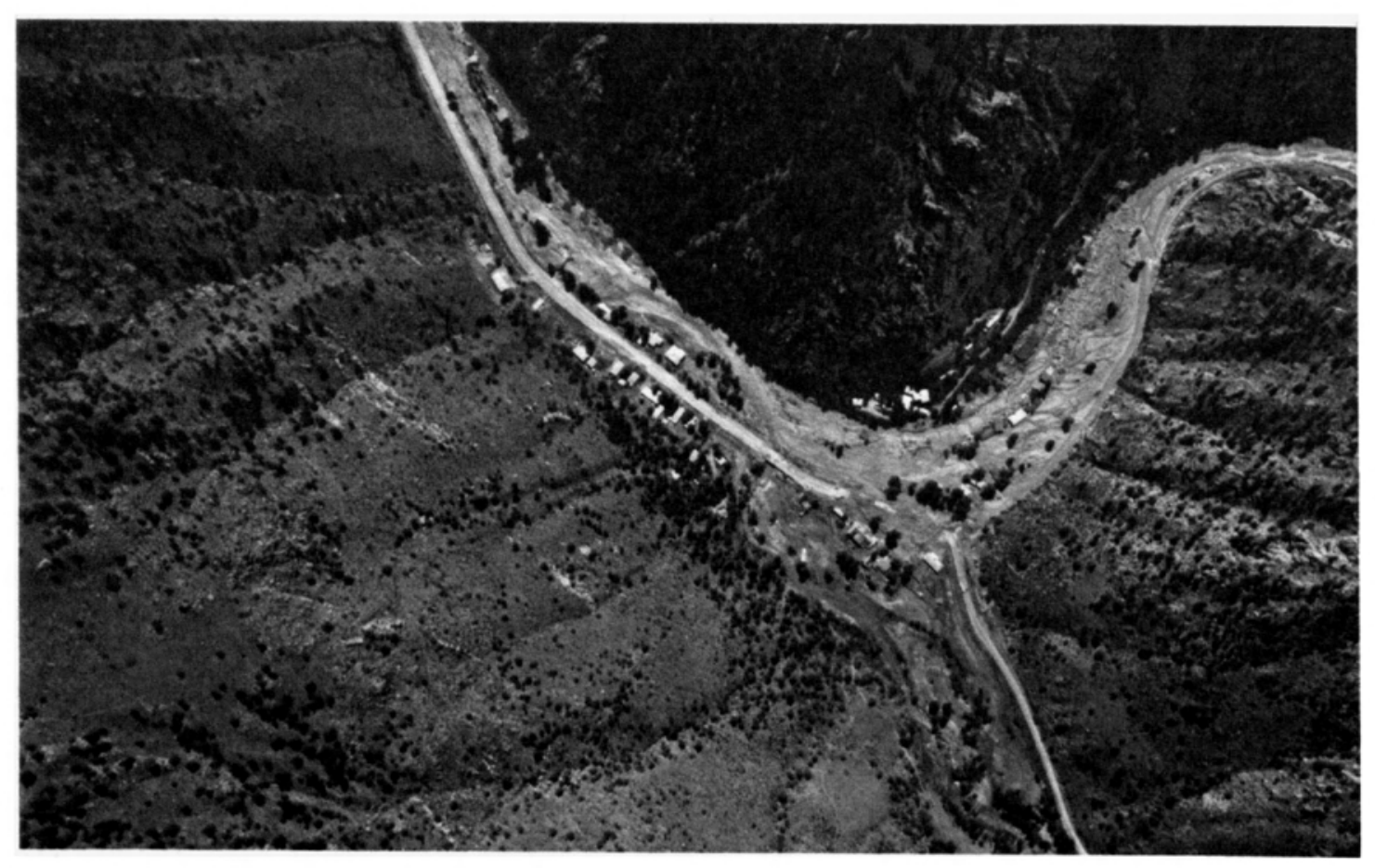

After the Flood

FIGURE 30 Drake 


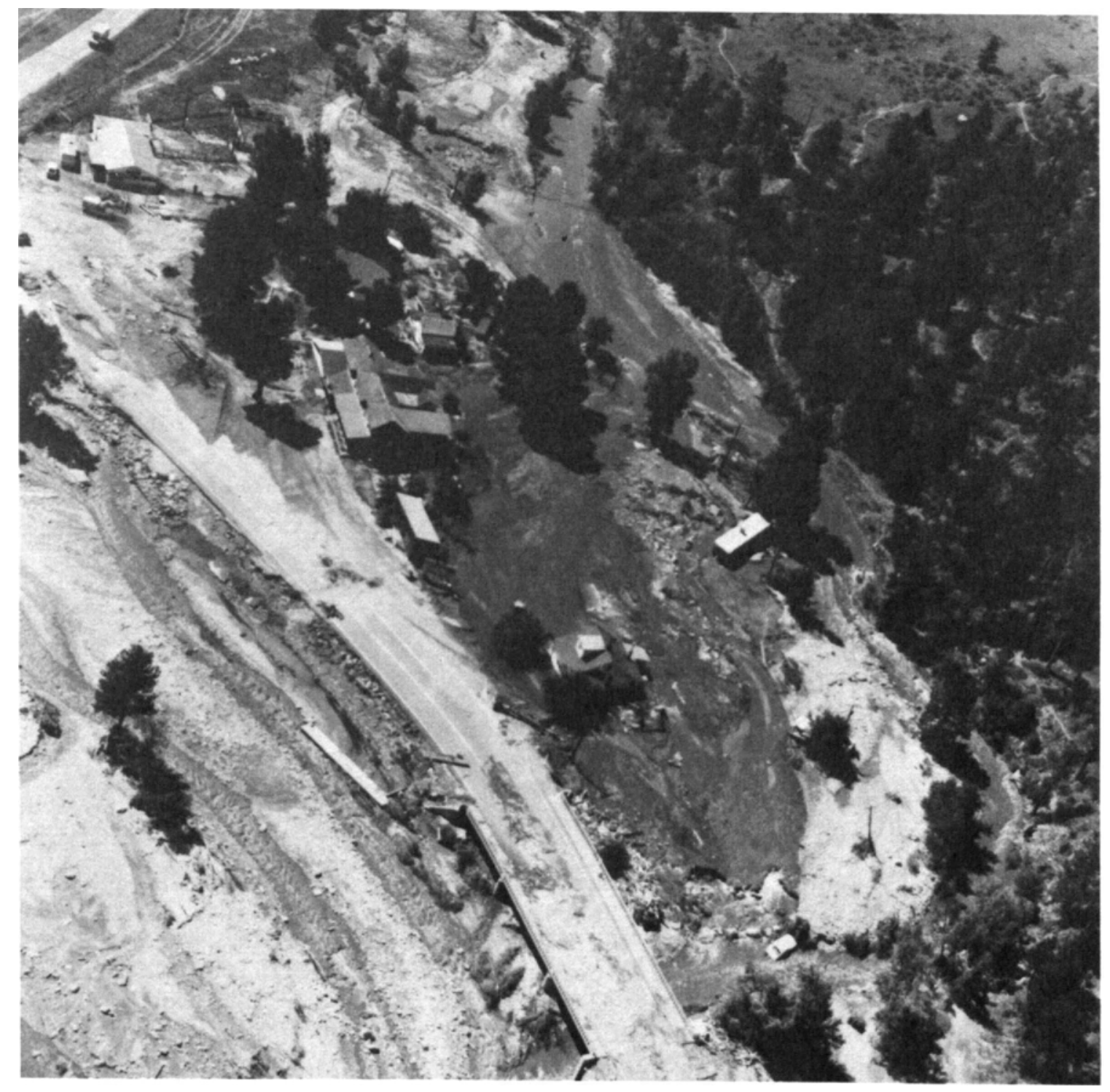

FIGURE 31 Deposits from the North Fork at Drake

the main crest of the Big Thompson river during later rises of the North Fork.

Downstream from Midway to the Loveland Diversion dam, the stream gradient increases slightly. Stream competence most likely included pebble to cobble sizes. Sands to cobbles were deposited in the overbank areas while silts could still be seen in the wide channel.

BT-4:-- This reach experienced moderate scour during the July 31 flood. Along this reach the valley narrowed to 100 to 200 feet while the slope was about 160 feet per mile. An area of severe scour occurred immediately downstream from the overtopped Loveland Diversion dam. The scour 
probably resulted from the surge that occurred at the time of dam failure. Much of U.S. Highway 34 was eroded away along this reach.

BT-5:--At loveland Mountain Park where the valley widens to over 250 feet and the slope changes little, sands to cobble sizes were deposited in the overbank areas.

BT-6:--Along this reach the valley narrows to less than 100 feet, greatly constricting flow. This reach experienced severe scour during the flood. Stream competence probably included boulder sizes.

BT-7:--At Cedar Grove, where the valley widens to about 400 feet, materials of all sizes were deposited in the channel and overbank areas. Figure 32 is a before and after aerial photograph of this region. Notice the scope of sediment deposits and the channel braiding at the upstream end of the reach, indicating overloading. Much of the material larger than sands eroded upstream was most likely trapped in the reach.

BT-8:--The Narrows, as its name implies, is a length of stream bordered by towering vertical rock walls, valley width averages about 120 feet and the gradient is about 200 feet per mile. Stream competence included boulder sizes. The scouring flood waters eroded U.S. Highway 34 almost completely along this reach. Figure 33 shows a short stretch near the Bureau of Reclamation Diversion Structure. In this photograph, notice the absence of the roadway and the size of the boulders which were deposited. At site 23 near the canyon's mouth, a velocity of $26 \mathrm{fps}$ was measured, which can be considered representative of the reach.

BT-9:--As the floodwaters moved out onto the plains, the discharge and velocity was quickly attenuated by overbank storage, resulting in the deposition of large amounts of material in overbank areas. As an illustration of the change in velocity, the average velocity measured 4 miles downstream at site 24 was $12 \mathrm{fps}$. The width of the flood plain along this reach ran from 500 feet to well over 1,000 feet, and the slope averaged about 40 feet per mile. As a result, large amounts of sands and silt materials were deposited in overbank areas. Figure 34 shows deposits just below the mouth of the canyon and Figure 35 shows deposits in an overbank area further downstream. Several channel changes occurred when the momentum of flow shortened the length of the channel by cutting off a bend. 


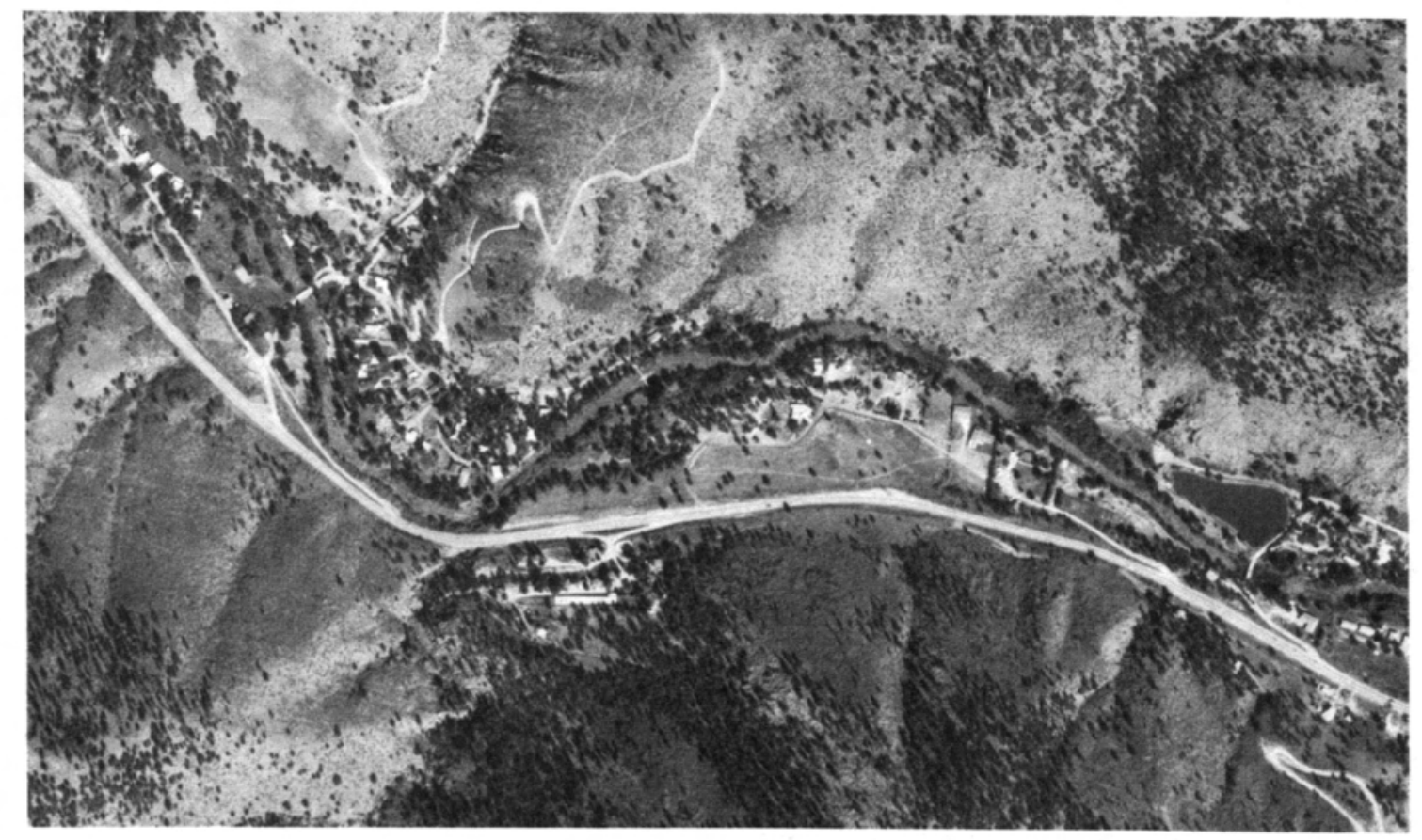

Before the Flood

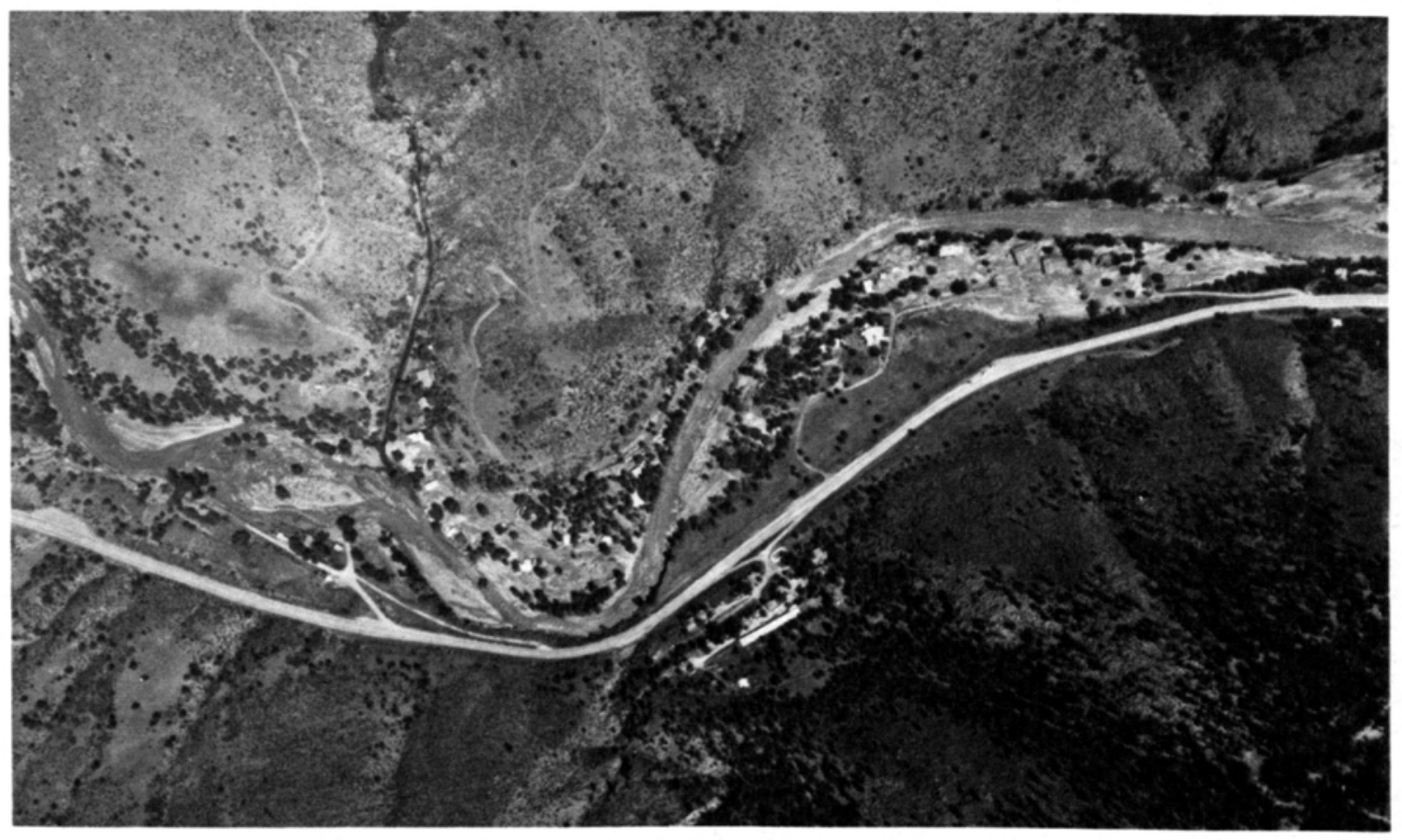

After the Flood

FIGURE 32 Deposits near Cedar Grove 


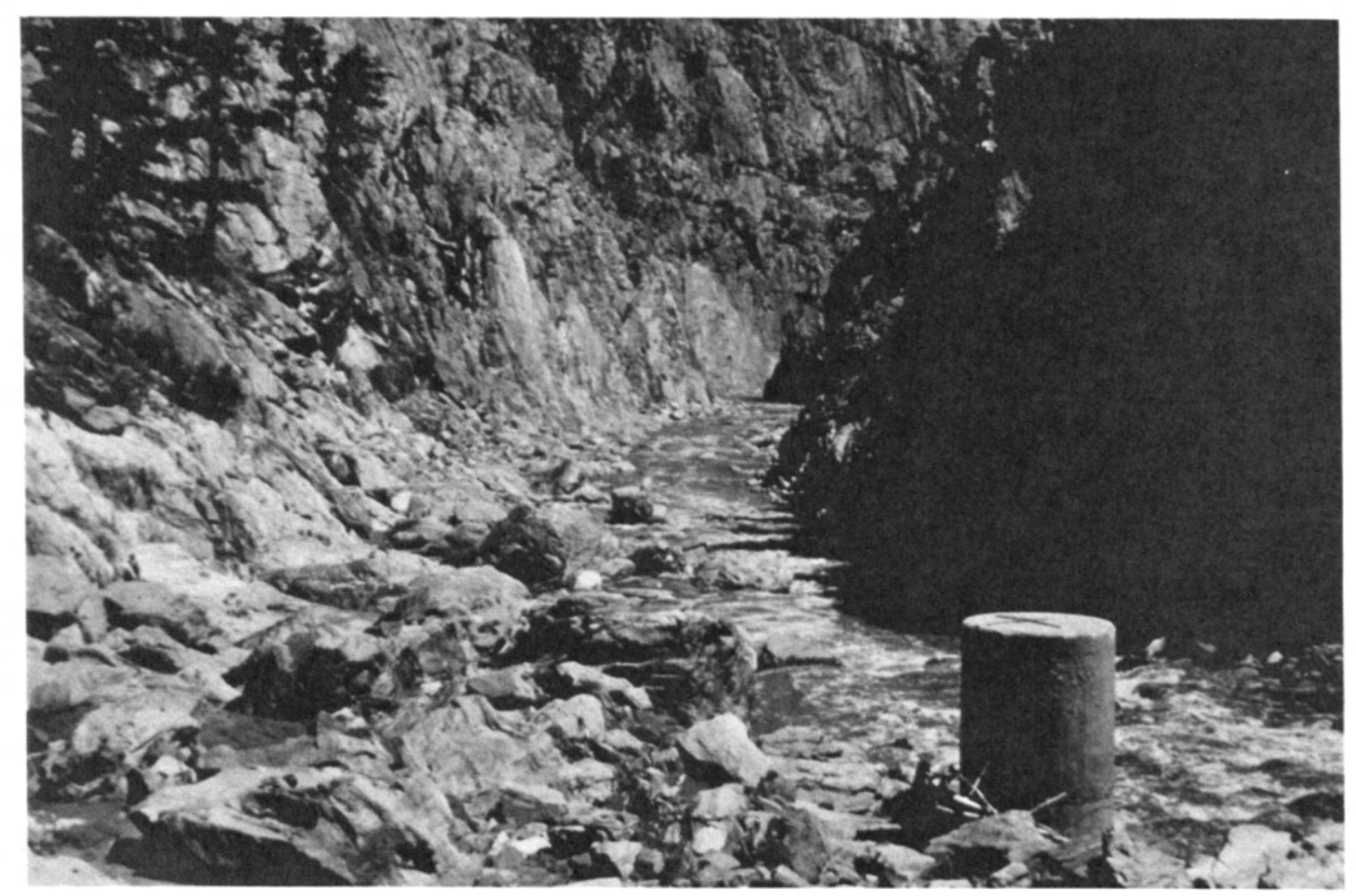

FIGURE 33 Scour in the Narrows Area near the Bureau of Reclamation Diversion Structure

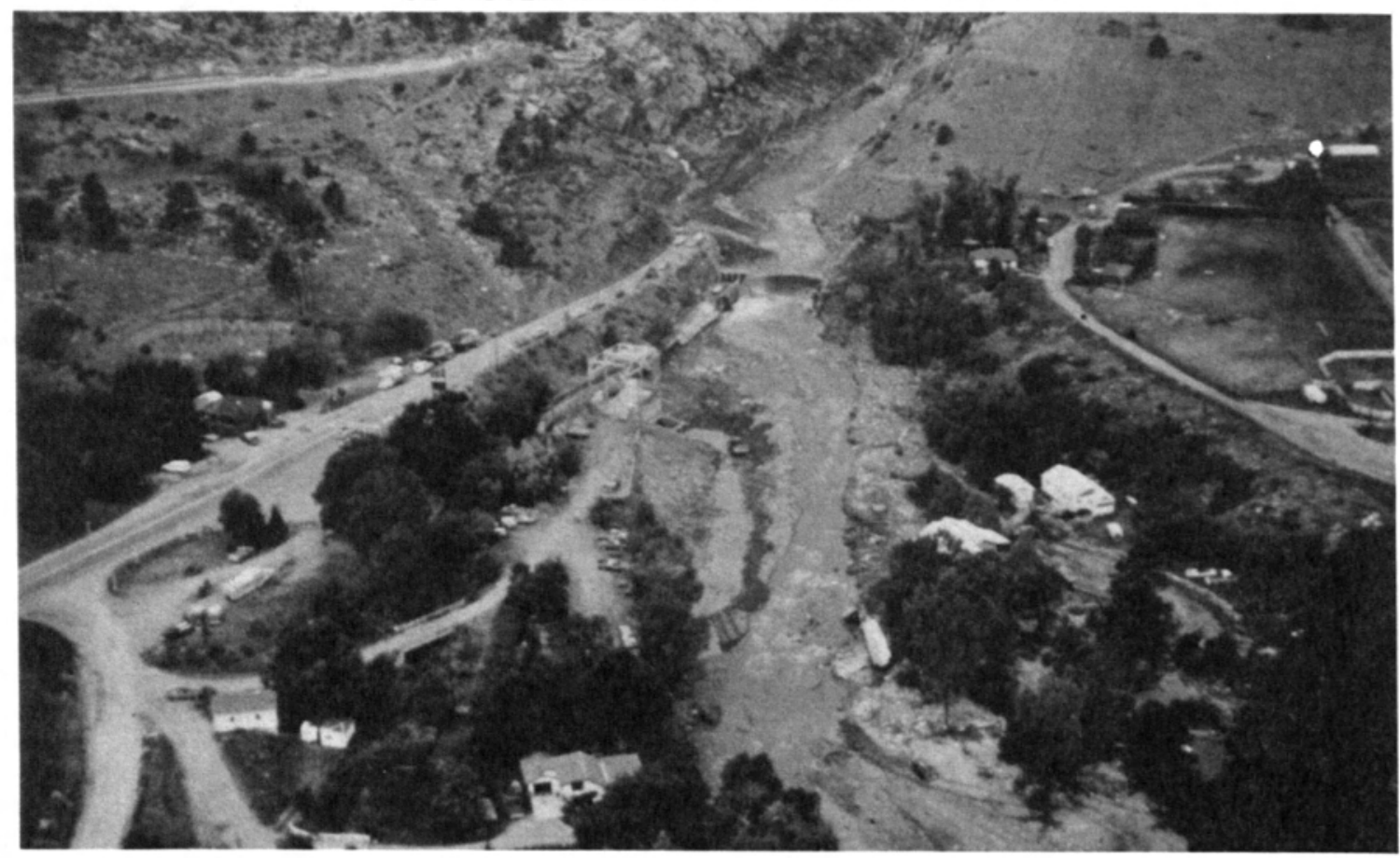

FIGURE 34 Deposits below the Mouth of the Canyon 


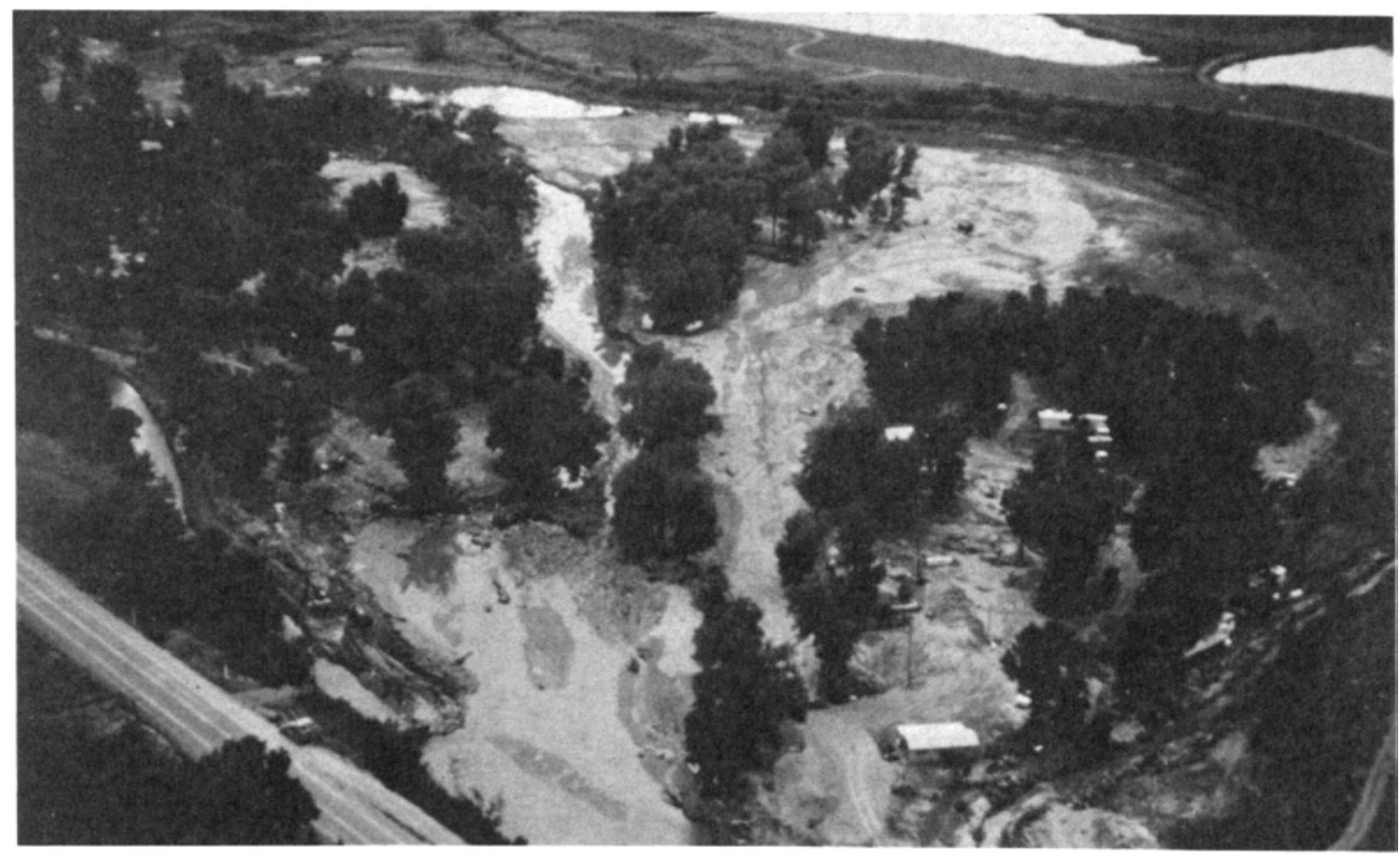

FIGURE 35 Overbank Deposits in the Plains Area

GEOTECHNICAL ASPECTS OF THE BIG THOMPSON FLOOD

The geotechnical engineering aspects of the damage caused by the Big Thompson river flood included several different catagories. Roadbeds, embankments, and bridge abutments were either partially of completely washed out. Building foundations were damaged or destroyed resulting in further damage to the superstructure. Many landslides were triggered when toes of slopes were undercut.

Slope instabilities manifested themselves as either an immediate slide or a failure that did not slide for days or months; some may not occur until years afterward. Emergency and clean-up crews, working within limited time constraints and having to make use of readily available materials did not enhance long term stability of road cuts and stream banks. Finally, erosion of dam foundations and earth embankments was a major concern and many hudraulic structures collapsed.

The photographs included herein, taken as much as a year after the flood, show the nature of the damage caused by the flood and the remedial measures taken in that time period. The text that follows is based on first-hand observation and discussions with other observers who entered the canyon shortly after the flood. 


\section{U.S. Highway 34 and Intersecting Roads}

The highway descends 2,160 feet in its 19 mile run from 01ympus Jam at Estes Park to Little Dam at the outlet of the Narrows. The width of the canyon base varies from 100 to 600 feet and in several places is wide enough only for the river and the roadbed. The road is primarily constructed on fill placed along the canyon walls. The road surface is somewhat low in many areas, often not over 10 feet above the riverbed. The road traverses from side to side, crossing the river many times. Curves are located on both inside and outside bends in the river. Highway embankments located near the river on the outside of a bend were particularly vulnerable. Figures 36 and 37 show areas in which the embankment was almost completely removed. Figure 36 shows an area along the highway whereas Figure 37 shows the secondary road between the dam and the bridge at the Loveland Filtration Plant. Damage such as shown was a common occurrence along the entire length of the canyon. Figure 38 shows erosion along the drainage area on the inside of the highway away from the river. Large volumes of flow along the inside of the roadway across from the riverside scoured out the base course near the edges and caused local pavement failures. Scour of the roadway, where the water flowed rapidly over the roadway, was not uncommon. Extensive gullying along roadways was also evidenced in the Dunraven Glade area north of the North Fork. Such gullying can be seen in Figure 39. Extensive erosion was fairly common along roadways or around man-made structures.

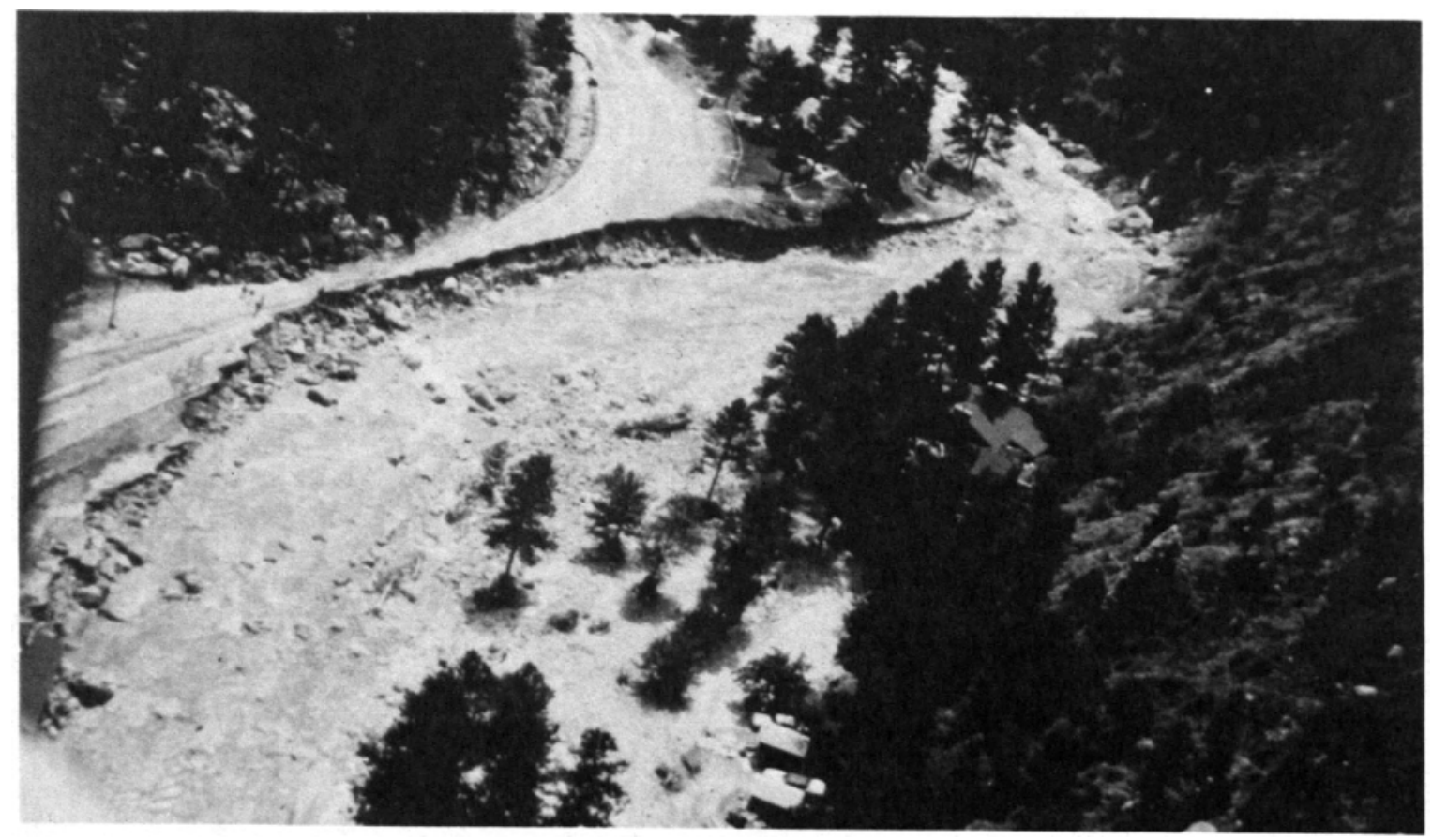

FIGURE 36 Erosion of Outside Bend on U.S. Highway 34 


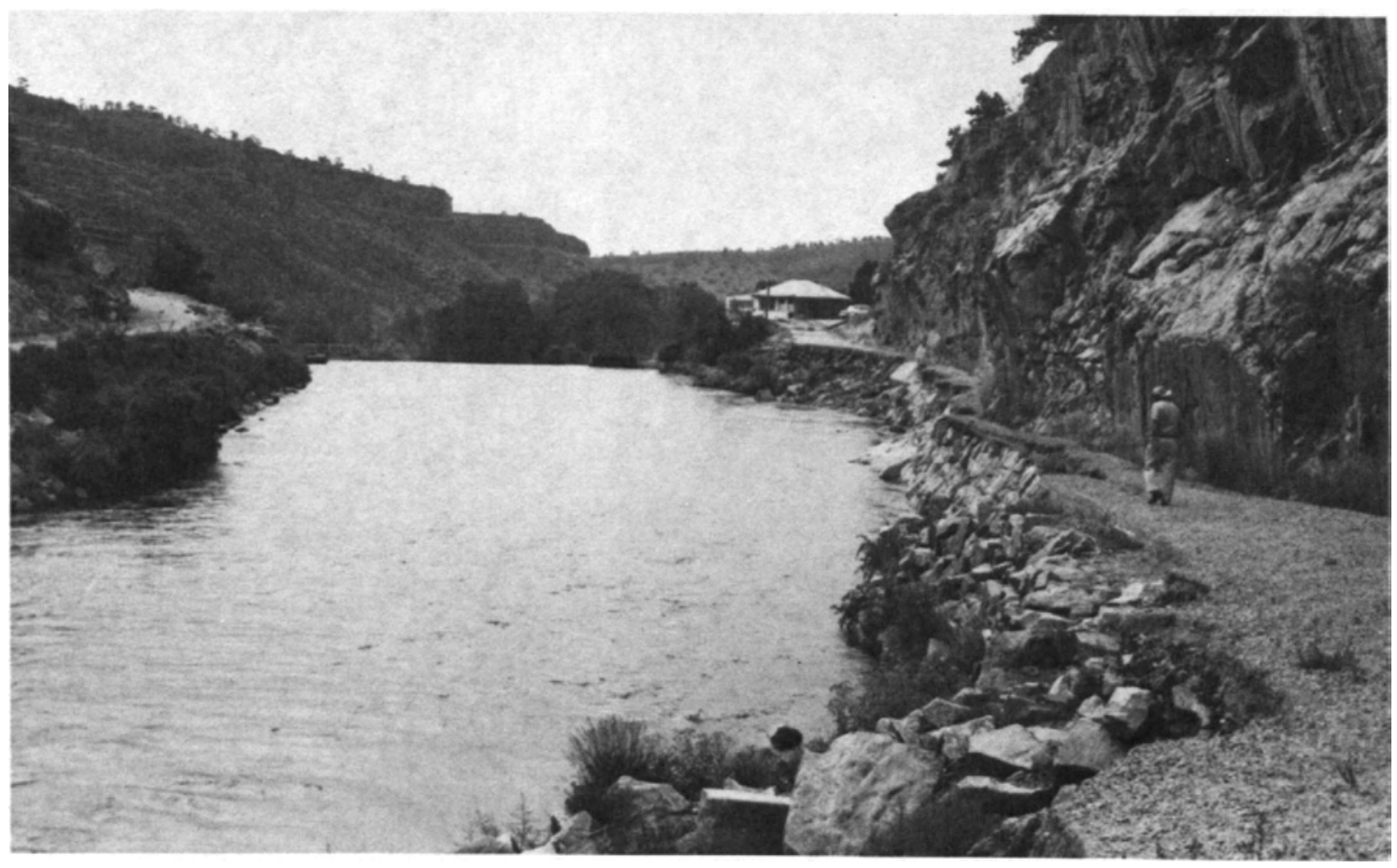

FIGURE 37 Erosion of Road between Bridge and Dam at Loveland Filtration Plant

Another type of failure occurred by the erosion of backfill material around bridge abutments. This can be seen in Figure 40 where the abutment was left standing and the approaches were washed out. This type of failure was not restricted to the Big Thompson Canyon. Heavy rains and flooding in the entire area washed out bridge approaches at several locations in neighboring areas. Consequently, several roads in the surrounding area were closed for as long as several days. The impact of those road closures on the disaster area, however, was not large and transportation in and out of Loveland was not severely hampered.

Another example of the failure of a bridge abutment is shown in Figures 41 and 42 . Figure 41 shows the river just upstream from the dam near the Loveland Filtration Plant. A steel truss bridge crossed the river between the abutments. Scour of the backfill material at the approaches is evident. However, the force of the water behind the abutment and on the bridge pushed the right abutment inward, as can be seen in Figure 42.

After the flood, considerable effort was put forth to restore the highway and in only a few months the road was paved from Loveland to Estes Park. In less than a year the road along the North Fork and Devils Gulch from Drake to Estes Park through Glen Haven was fully paved. 
FIGURE 38 Scour in Drainage Ditch on inside of U.S. Highway 34
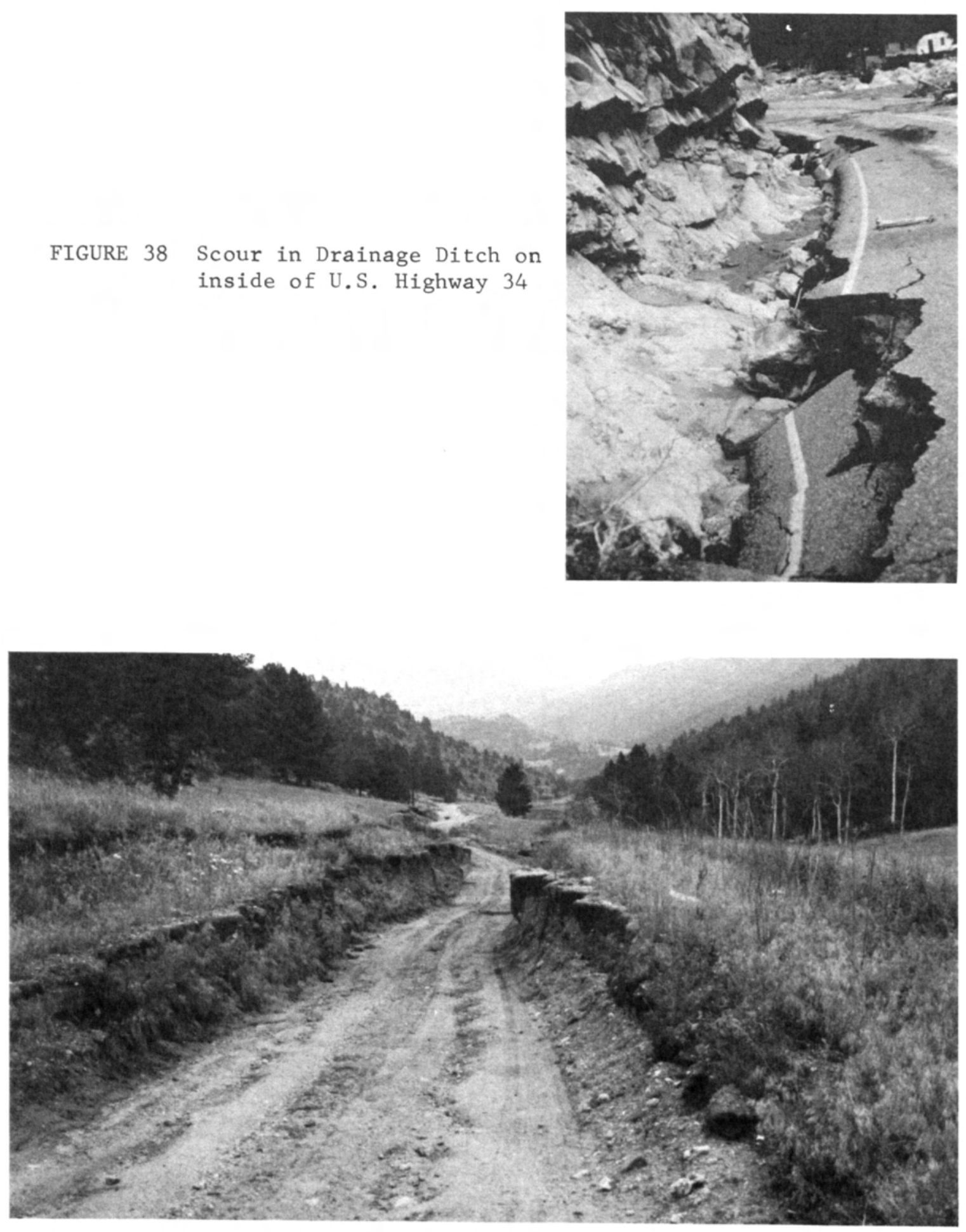

FIGURE 39 Extensive Gullying in Dunraven Glade Area 


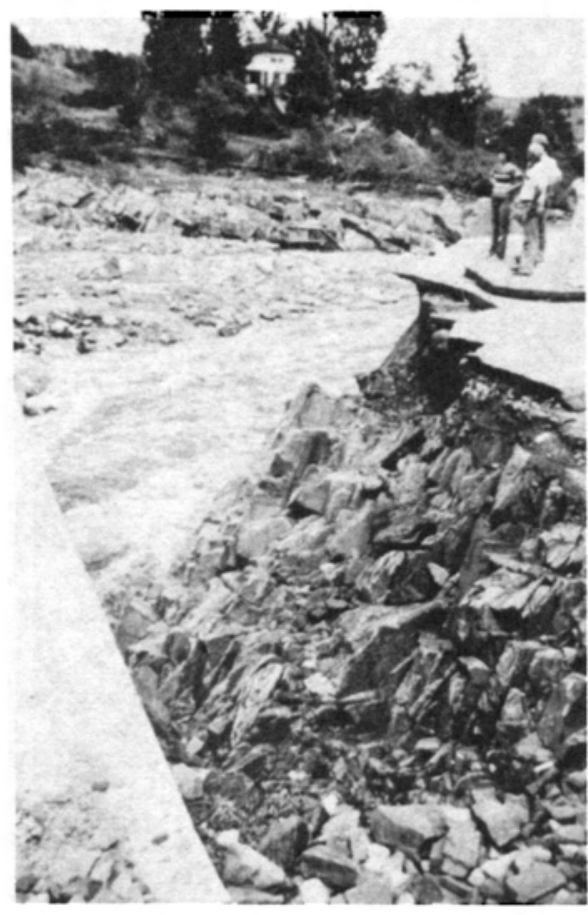

FIGURE 40 Erosion of Backfill Material at Bridge Abutment

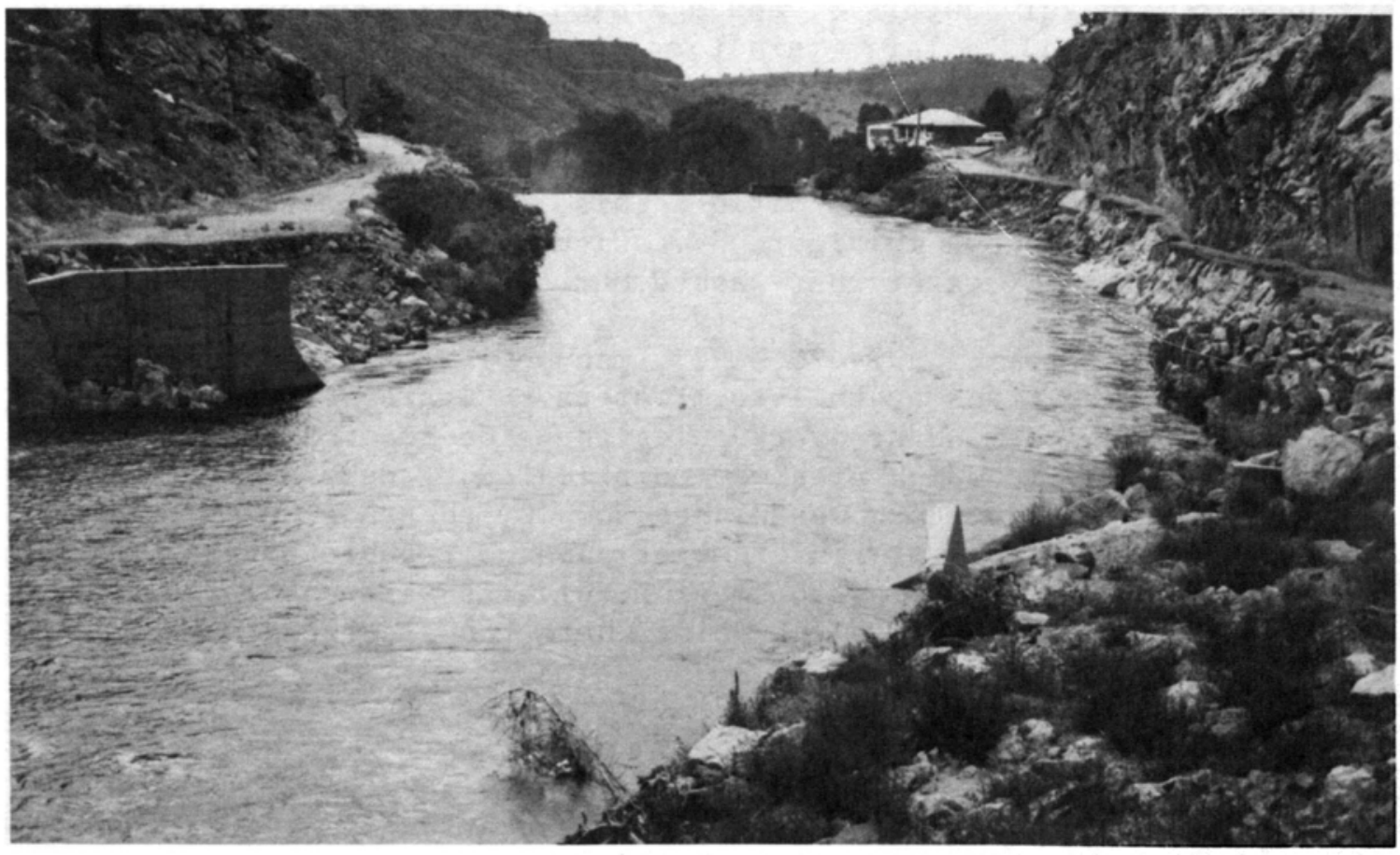

FIGURE 41 Abutments of Destroyed Bridge near Loveland Filtration Plant 


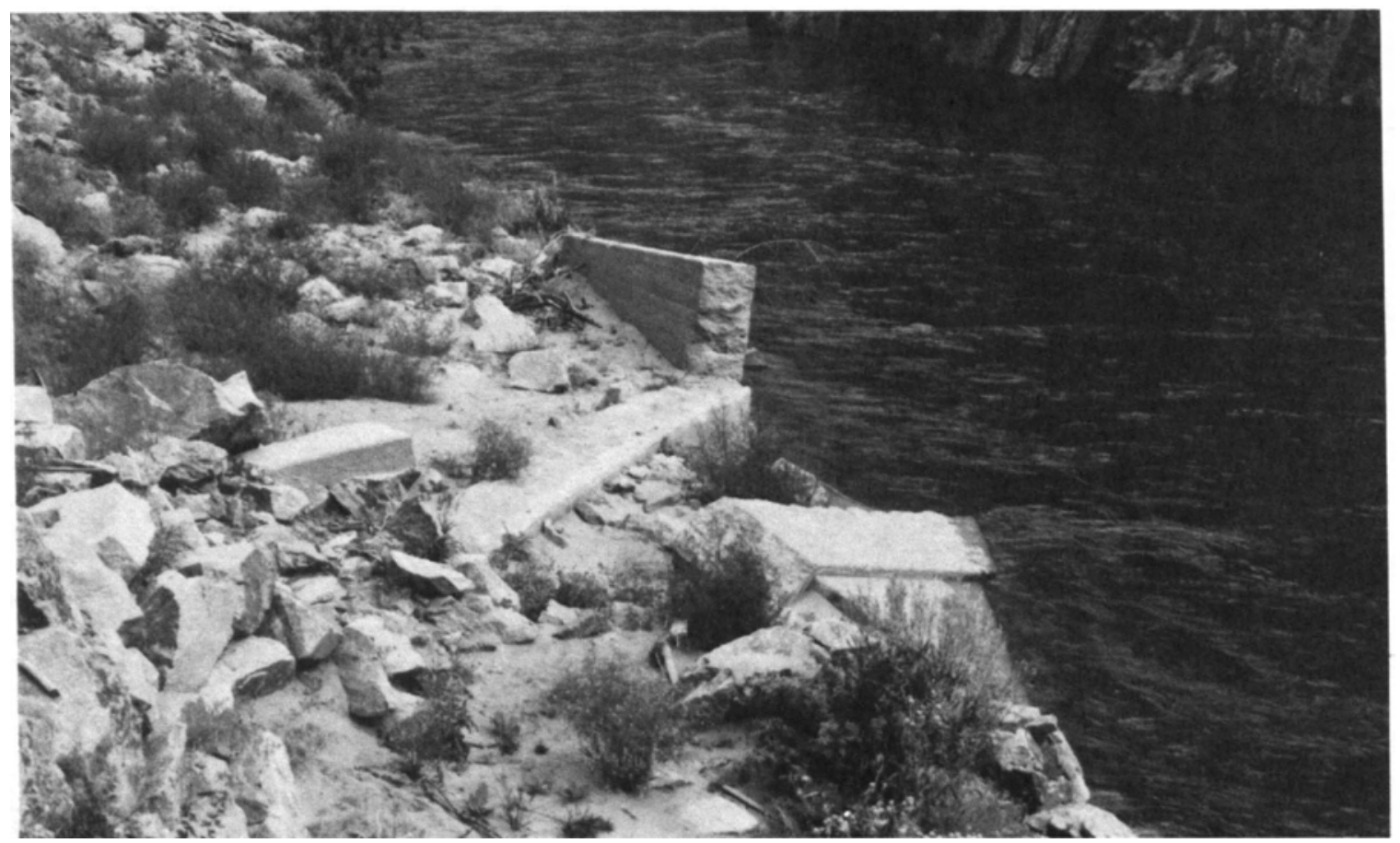

FIGURE 42 Close-up View of Right Abutment Shown in FIGURE 41

However, on July 20, 1977, and again on July 24, 1977, near1y a year after the flood, a large rainstorm again hit the area before adequate riprap could be placed for slope protection. Figure 43 shows some erosion that resulted to the road embankment in the Devils Gulch area along the stream. Figure 44 shows erosion on the opposite side of the roadway along the drainage ditch. This localized pavement failure is similar to that shown in Figure 38. Figure 45 shows erosion of the highway embankment by water that washed out of a dry gulch to the right of the figure.

During the storm of Ju1y 20, 1977, many culverts beneath side roads were inadequate to transmit the storm waters. Figure 46 shows one such culvert with the storm water overrunning the side road. This situation throughout the Devils Gulch area was complicated by debris left by the flood of July 31, 1976, that was washed down by the subsequent storm. Large culverts ( $4 \mathrm{ft}$ or more in diameter) had no trouble passing the storm water. However, where two smaller culverts were used, the debris decreased their competency to the point where the side road was overrun by the water.

\section{Structures and Foundations}

The Big Thompson Canyon has been a favorite vacation and resort area in Colorado. As a result, many of the buildings have been constructed for the summer trade. These include summer homes, tourist motels, and gift and souvenir shops. Many of these are attractively built with stone and timber facing. 


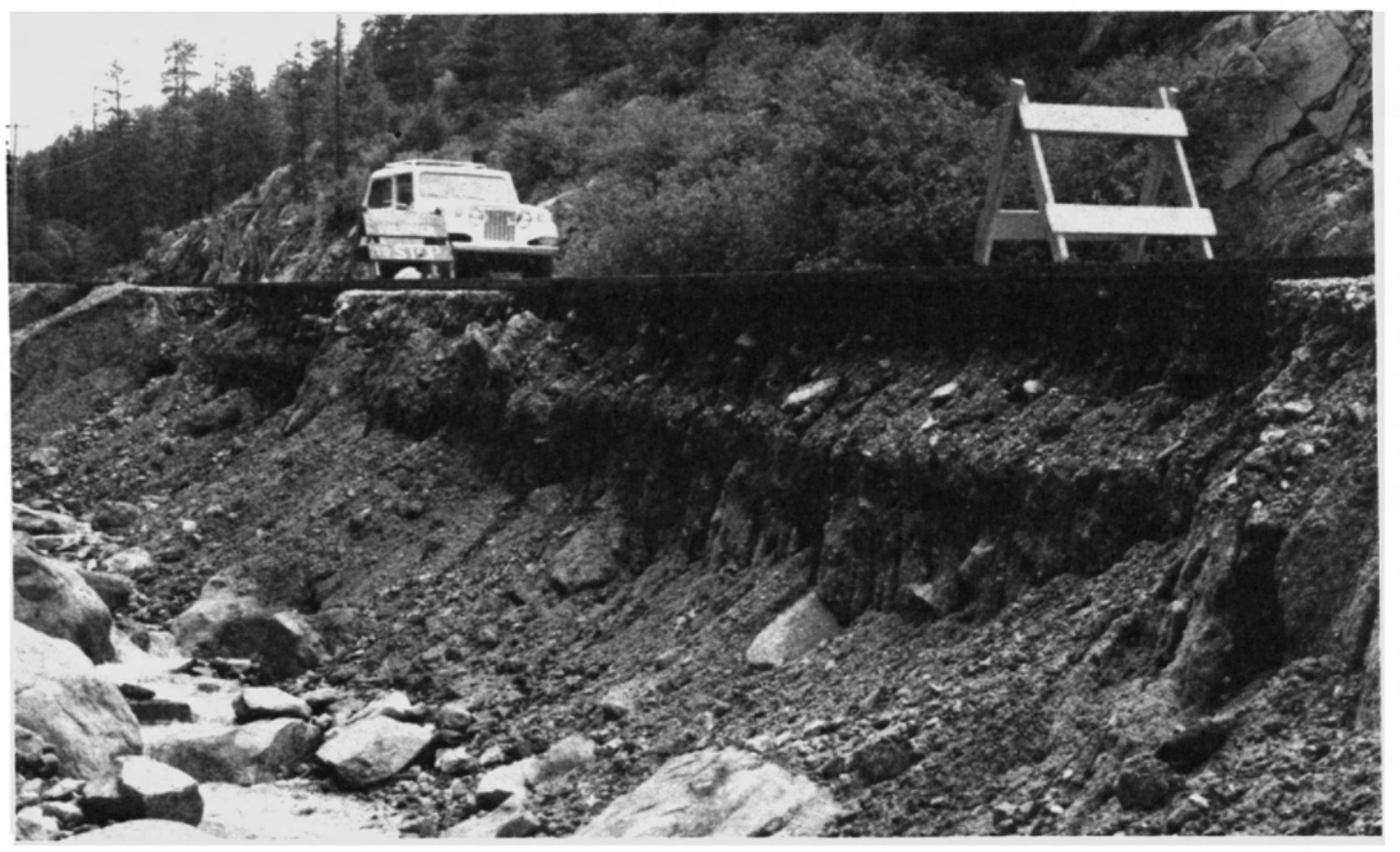

FIGURE 43 Repaired Highway Embankment Washed out by Subsequent Storm

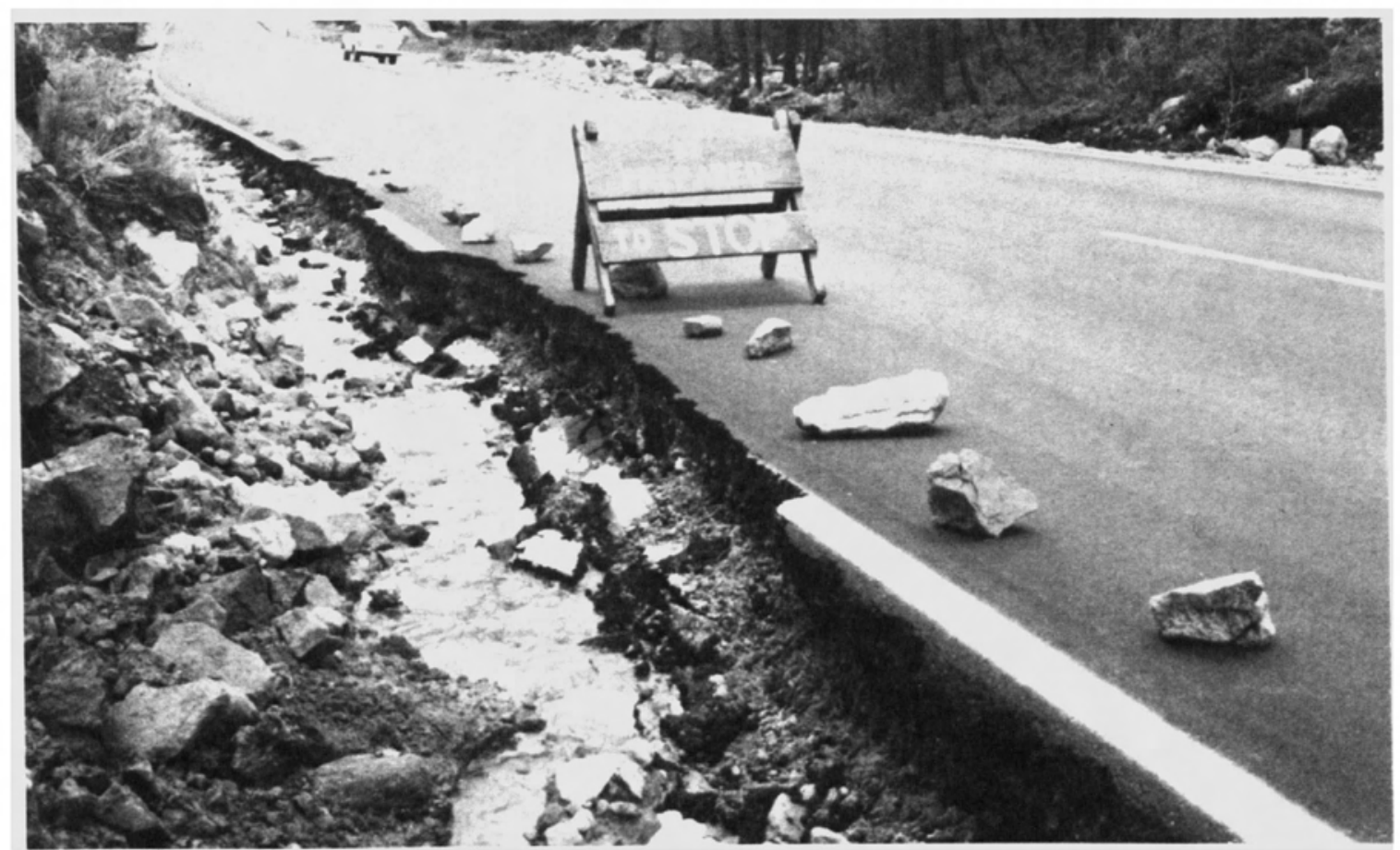

FIGURE 44 Repaired Pavement Eroded by Scour in Drainage Ditch 


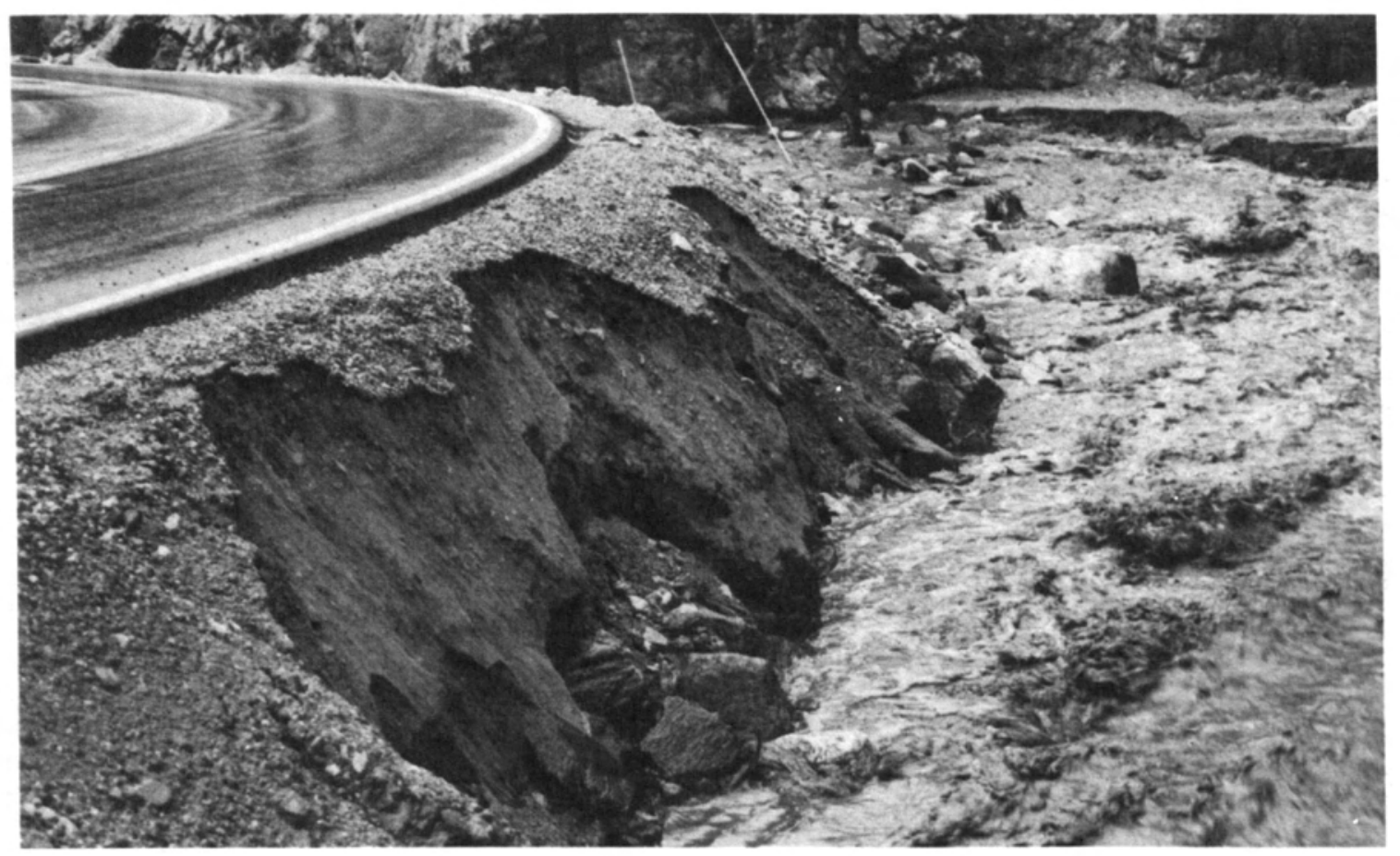

FIGURE 45 Repaired Highway Embankment Eroded by Water from Tributary

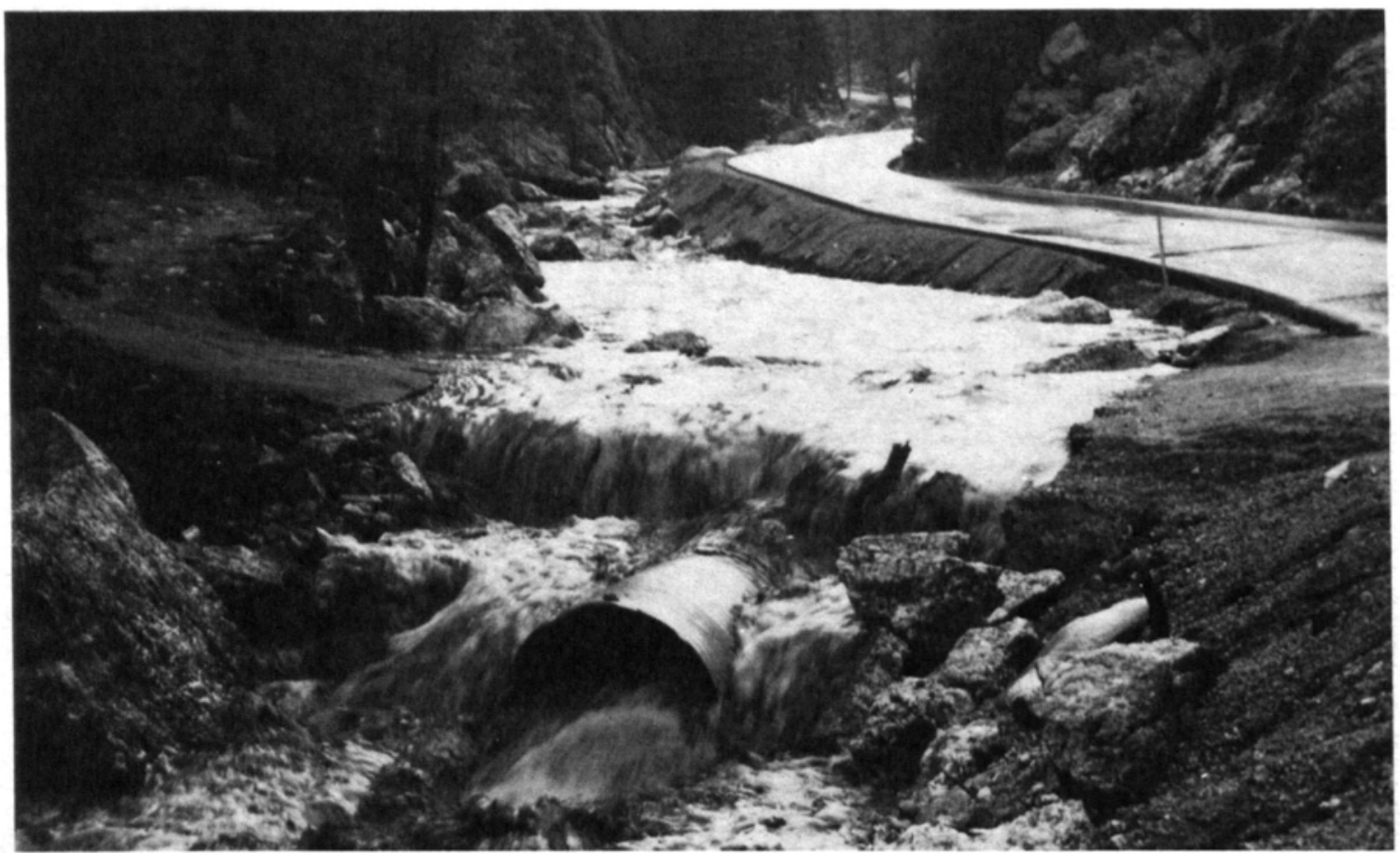

FIGURE 46 Storm Waters Washing over Culvert 
Zoning was initiated in Larimer County in 1963. The mountain area from Loveland to Estes Park, through which the Big Thompson River flows, was zoned as "Open District." Such zoning permitted any usage not prohibited by law with a few minor exceptions. Minimum building setbacks were established as the greater of 75 feet from the centerline of a public road right-of-way or 30 feet from property lines. No provisions or guidelines were established for floodplain management or for setback from rivers.

The Comprehensive Zoning Resolution for Larimer County, Colorado, as Amended, November 29,1973 , greatly restricted the permissible land use to such items as "1) Single Family Dwellings...4) Community Halls and Churches...9) Home Occupations...11) Guest Ranches, Resort Lodges, and Resort Cabins but not including Hotels and Motels." In addition, several more restrictions were imposed, including one requiring that structures be constructed no closer than 100 feet from the centerlines of established watercourses. That restriction eliminated the construction of structures on the riverbank but did not take into account floodplain management.

Many of the canyon buildings were constructed before the 1963 zoning restrictions and most before 1973. Many were not built for winter occupancy. Foundation bearing material posed few structural problems and consequently, the foundations were often inexpensively built with insufficient regard to proper foundation design. Depth of soil is usually very thin but may be several feet thick on debris fans or on depositis along the river. Houses were often built where suitable foundation material was available and where small yards could be constructed. These locations were therefore close to the riverbed where sand was available or on debris fans deposited at the base of side gulches.

Buildings were often built as close as possible to the river. In at least one case, a motel was partially built over the river to enhance its tourist appeal. This was not possible after the 1973 zoning amendments.

The town of Drake was almost completely destroyed with few structures surviving the flood. Figure 47 shows what remains of the town of Drake after the flood. This town was located at the point of confluence of the North Fork and the Big Thompson Rivers. Almost all of the buildings were completely destroyed.

Many building foundations were not well suited for flood conditions. Most small buildings were built on small timber or masonry block footings. If the foundation bearing was rock or boulders so that the surface was irregular, small cylindrical concrete piers often were used as support posts. That procedure made it possible to level the buildings and provide additional height for protection from rising water. However, the piers provided very little restraint against lateral forces imposed by the floodwaters. Other foundation structures that were employed were slabs on grade or conventional foundation walls and spread footings.

Figure 48 shows the remains of the Loveland City Power Plant. The foundation structure survived well but the entire masonry superstructure and large generators were washed away. Wooden structures were often floated off the foundations and deposited at a different point. 


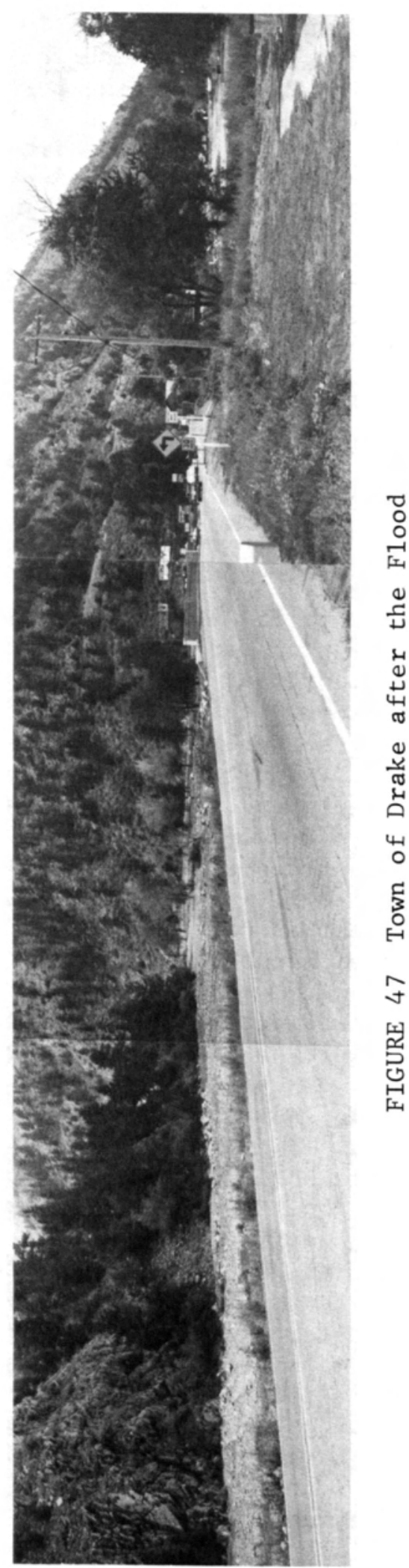

58 


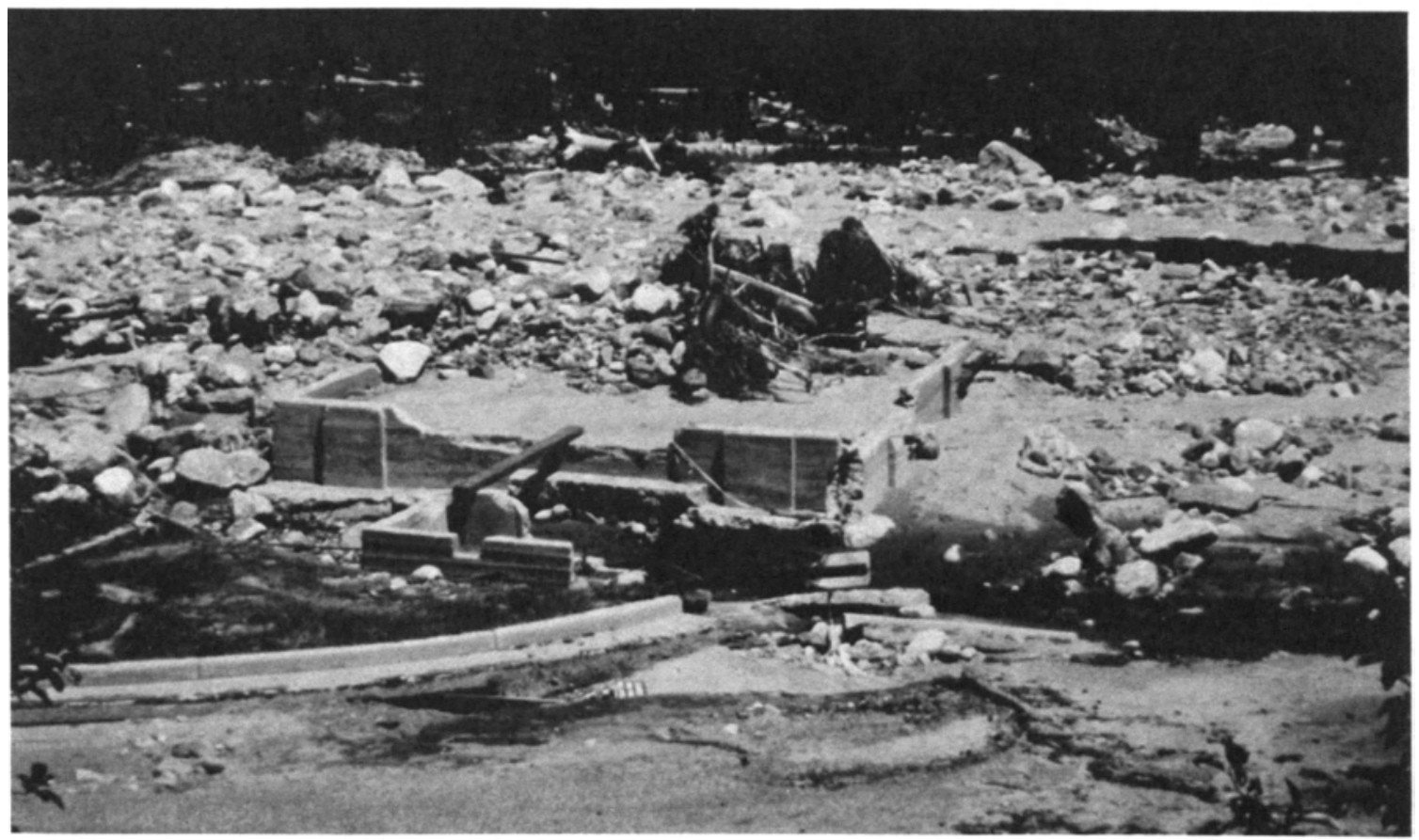

FIGURE 48 Loveland Power Plant

Failure of foundations could be grouped into two categories, a) failure of the building's foundation structure or b) failure of the foundation bearing material.

Figures 49 and 50 show two masonry foundations that failed as a result of the lateral forces exerted by the floodwaters. In general, masonry foundation walls of either block or stone did not withstand the flood as well as concrete foundations.

Some research has been conducted with regard to the design of structures to withstand forces exerted by floods (flood proofing). The construction of foundations such that the walls perpendicular to the direction of flow are allowed to fail permitting the floodwaters to pass below the superstructure may be a valuable concept in flood proofing. The walls parallel to the direction of flow should be reinforced such that they can withstand the flood forces. This practice has been utilized in some instances in coastal areas subject to potential flooding by hurricanes.

Failure of foundations due to erosion of the foundation bearing material can be seen in Figures 51 and 52 . (The rubble to the left of the building in Figure 51 was placed there during the clean-up operation.) In this particular instance the failure of the weaker parts of the masonry foundation reduced the flood forces on the remaining portions such as was discussed with regard to Figure 50 .

The structure in Figure 52 was constructed on a debris fan formed below a gulch that is normally dry. In the following section this type of failure will be discussed in more detail with regard to slope stability. The point to be made, however, is that, although the floodwaters 


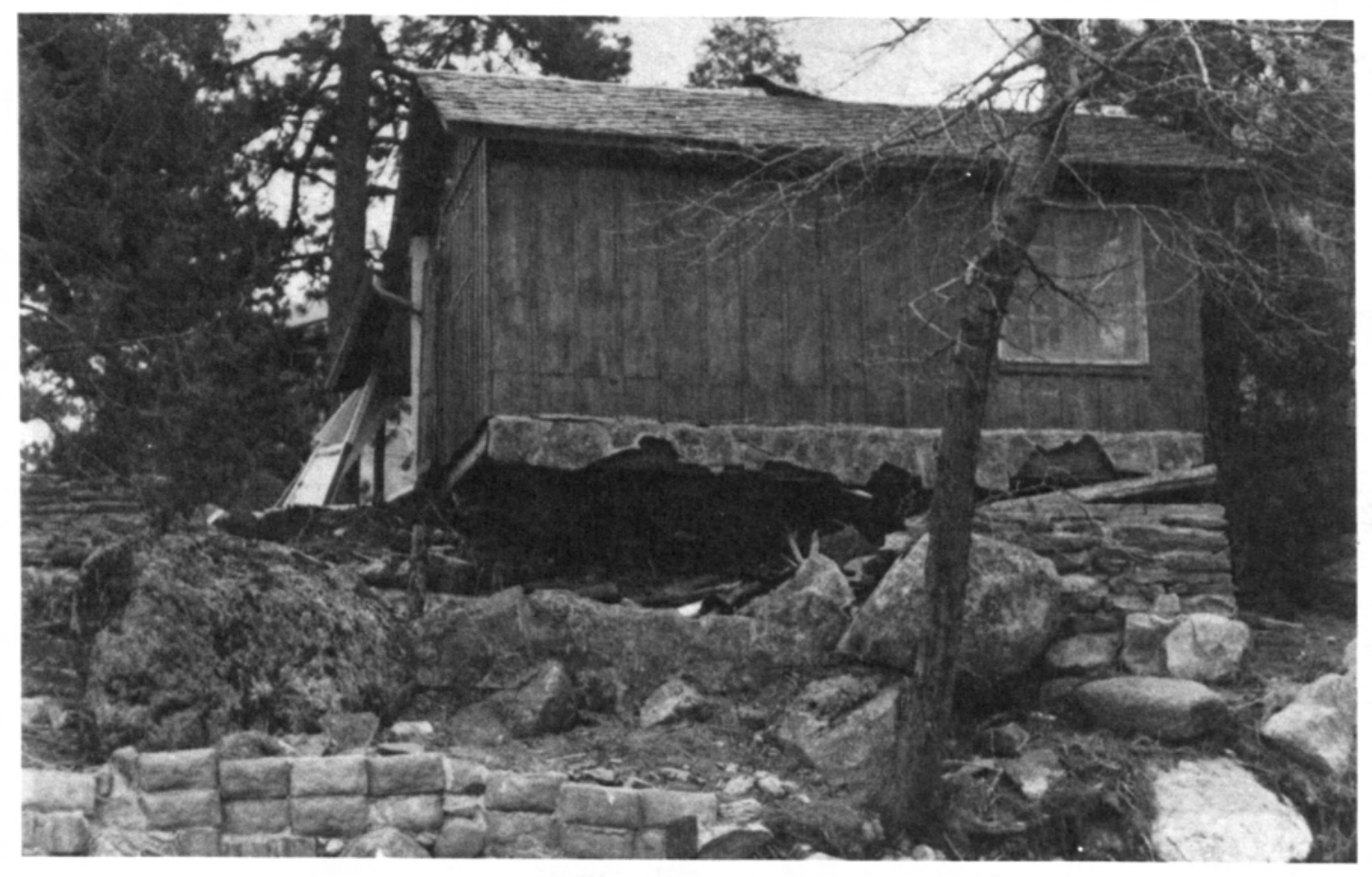

FIGURE 49 Failure of Timber Foundation with Stone Masonry Facing

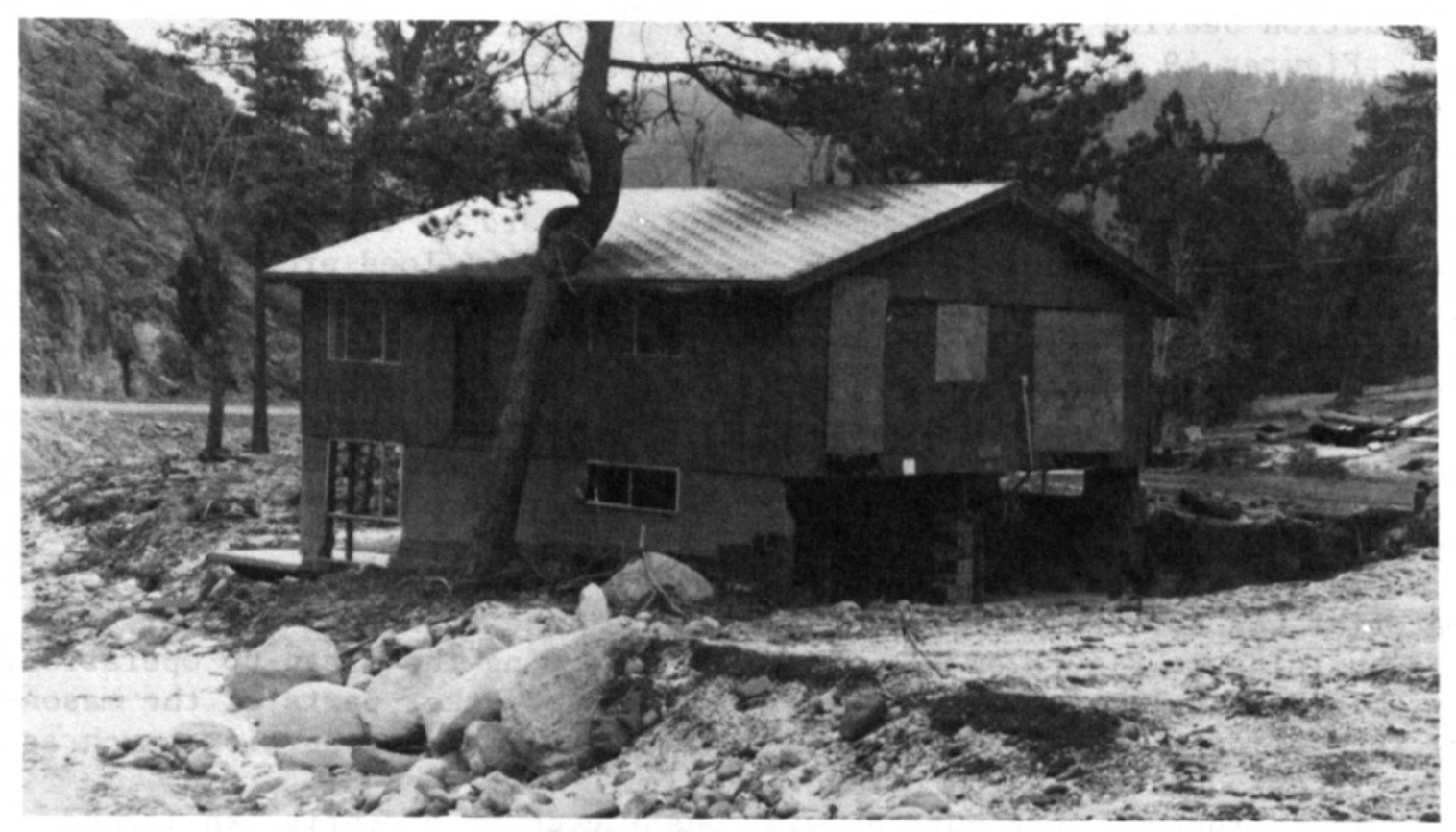

FIGURE 50 Failure of Concrete Block Foundation 


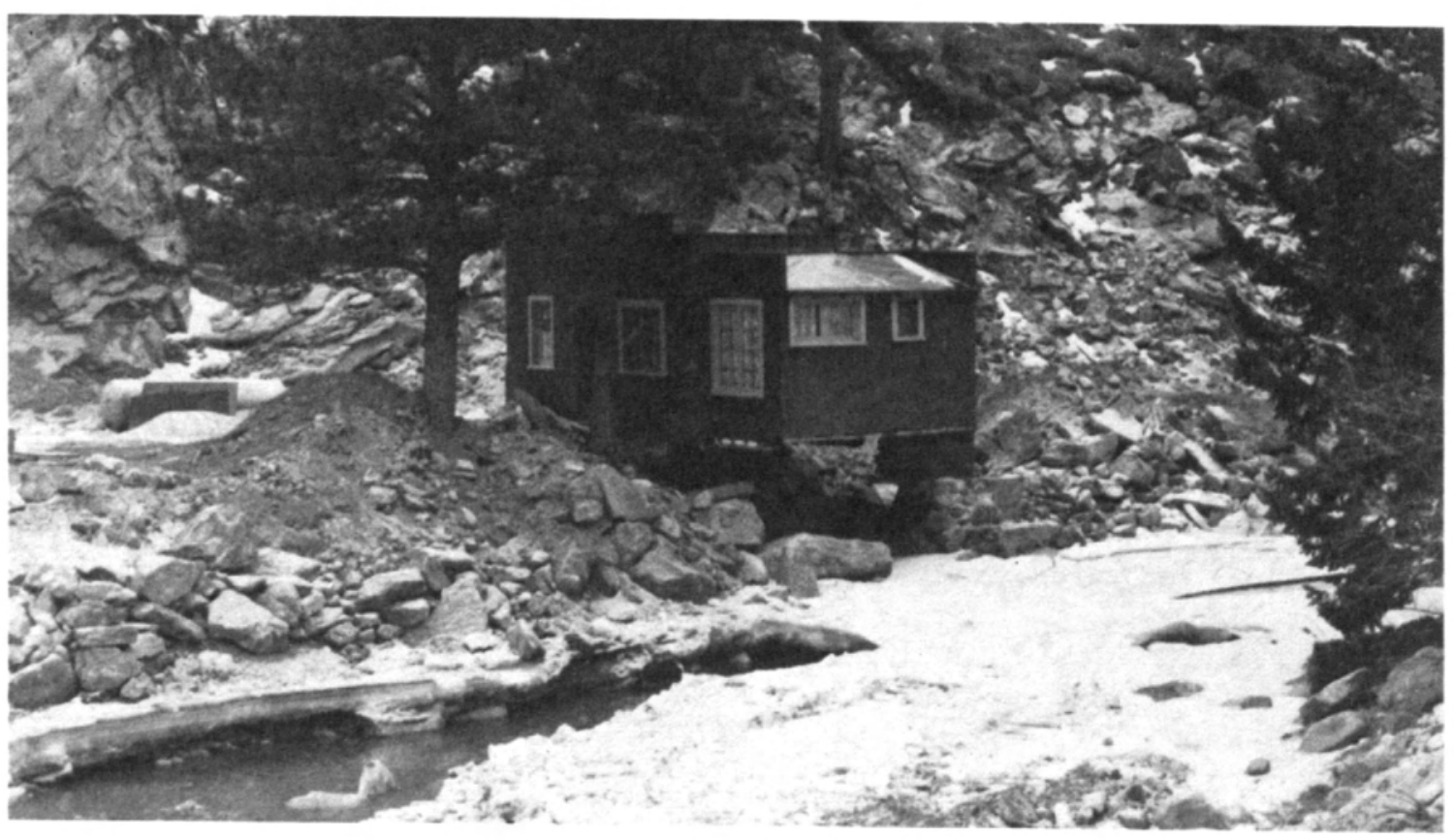

FIGURE 51 Erosion of Foundation Bearing Material

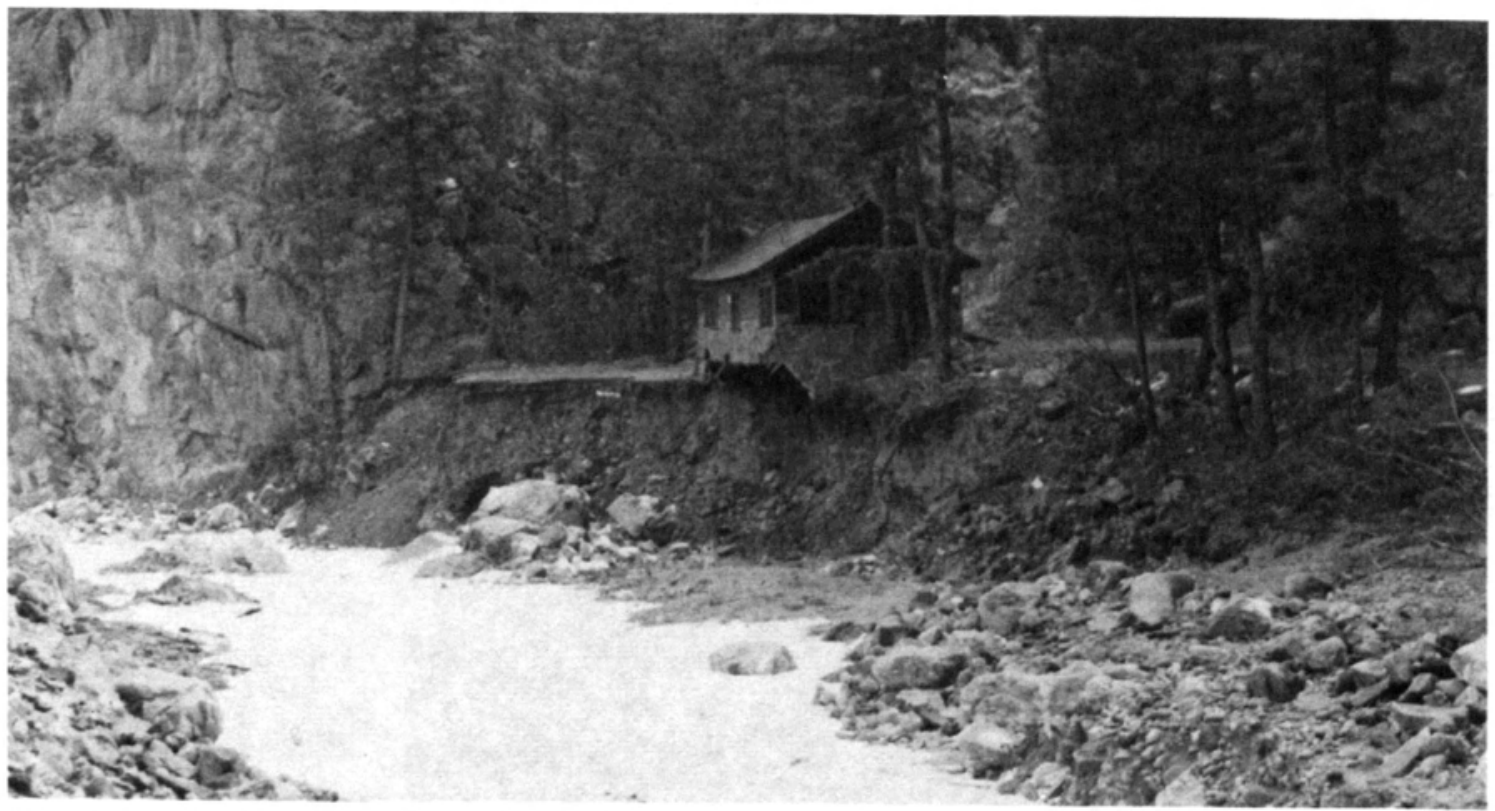

FIGURE 52 Erosion of Debris Fan below Foundation 


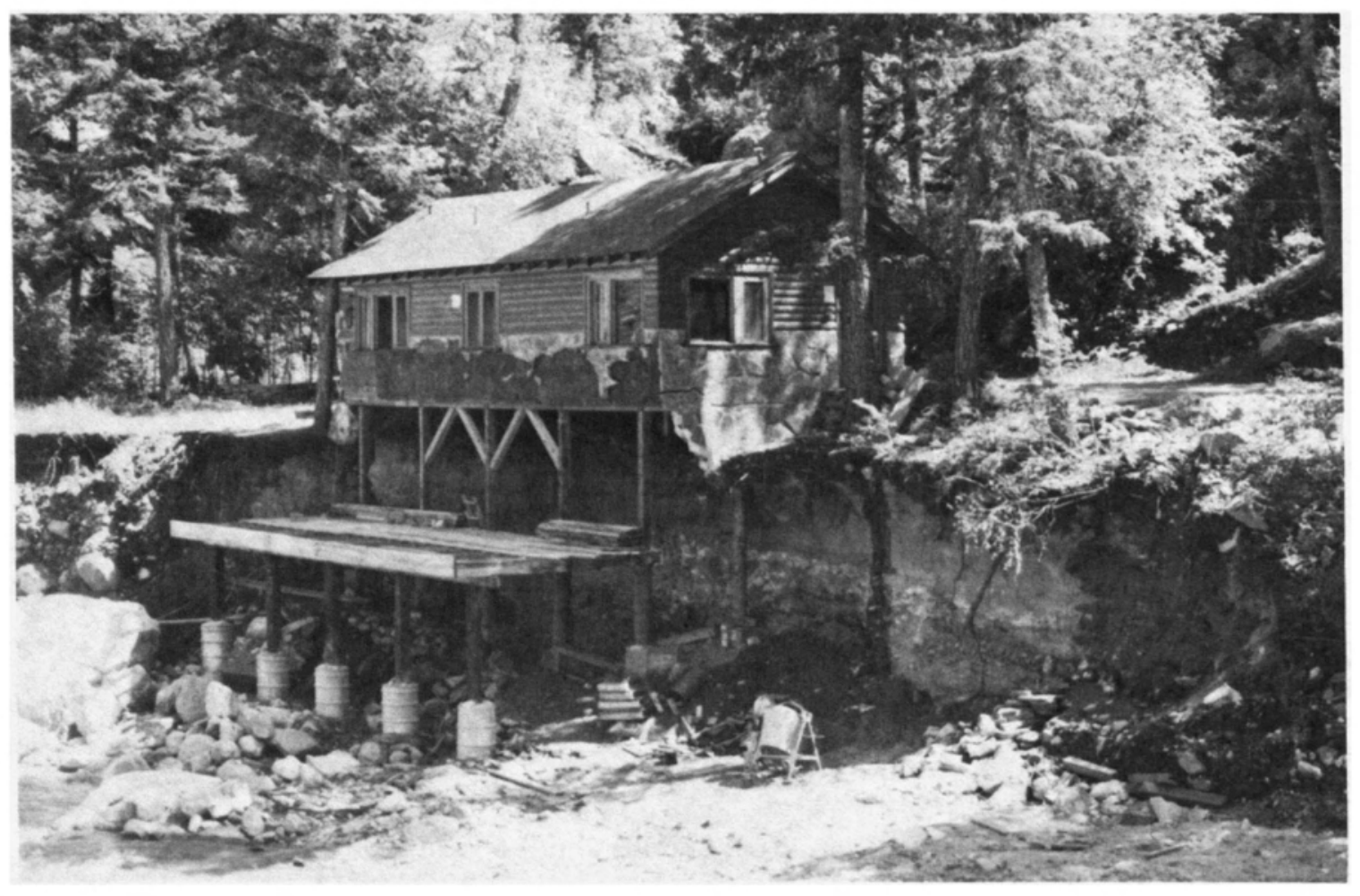

FIGURE 53 Remedial Measures Being Taken for Foundation Repair

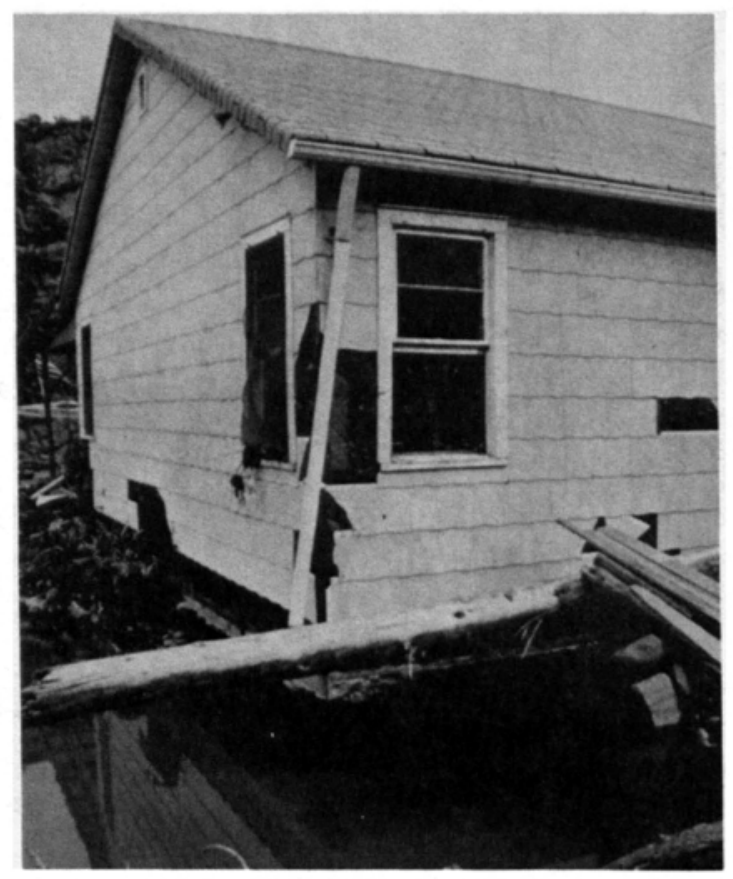

FIGURE 54 Erosion below Slab on Grade Foundation 
may not have actually contacted the structures, the erosion of the foundation bearing material may result in failures of the structures. Such situations may not be remdied merely by floodplain management. Structures constructed above floodplain elevations can still fail due to erosion of foundation soil or slope failures triggered by erosion of seepage. The importance of an adequate site investigation and geologic hazard report prior to construction should be emphasized.

of some interest is the nature of the remedial measures being employed for the structure shown in Figure 52. Figure 53 was taken almost one year after the flood. It appears that the owner has confidence that another flood is a significant time period away.

Erosion of soil below a slab on grade can also be seen in Figure 54. A1though the effect shown in this figure is not extremely dramatic, it illustrates the consequences of building in areas subject to scour and the fact that scouring action may be induced due to placement of the structure in that location. More dramatic effects did occur but left little to photograph (e.g., Figures 47 and 48).

Slope Stability

The canyon walls of the Big Thompson river are fairly steep, with slopes ranging from 10 to 60 degrees with averages between 25 and 35 degrees. Because of the steep slopes often encountered, the residual soils are usually thin and in many areas the rock is exposed. The natural slopes exhibit a factor of safety close to unity and the greatest depth of soil occurs in the talus slopes where the material falls or in debris fans deposited below gulches intersecting the canyon. Soil depths in these areas may range from 10 to 30 feet.

Some soil stability is gained from the vegatation cover composed of grass, small bushes, and trees. The roots of this growth provide protection from rainfall and wind. The increased strength of the upper zone of soil is illustrated by ledges of that zone up to a foot thick that protrude beyond a wall of soil which has been eroded beneath it. This is evident in Figure 55 and in many of the following photographs.

The flood affected the stability of slopes in several ways. Perhaps the most common cause of slope failures was the erosion of soil around the toe causing an increase in stress to the point where a slide would occur. Secondly, seepage forces were induced in the slopes due to infiltration of rainfall or due to release of bank storage as the flood subsided, similar to rapid drawdown of dams. A third factor of the flood that may contribute to instability of slopes is the removal of vegatation resulting in the loss of strength of the overlying root zone cover. This probably would not cause immediate instability but may result in landslides developing even as late as several years after the flood. Causes of removal of the vegatation were primarily erosion of top soil or slides forming on upper hillsides. In some instances soil was eroded from below boulders that then crashed down the side of the canyon.

Long term failures may also be induced by changes in the geometry of a slope due to erosion. The increased stresses resulting from the steepening of slopes may cause accelerated creep and eventual creep 
failure of slopes.

Finally, clean-up crews removed soil and rock that accumulated at toes of slopes. In several cases, relatively steep banks were left along roadsides and near the streambed. Such slopes, bare of vegatation and subjected to relatively high stress levels may be susceptible to progressive failure.

Slope failures and landslides occurred in different ways. Pore pressures built up in cracks and joints caused a small number of rock falls. Landslides occurred in the residual soil covering rock slopes and in colluvium below slopes. Erosion of the toes of debris fans also caused slope failures.

The largest rock-fall can be seen in Figure 56. The light colored rock in the center of the photograph shows the area from which the rock fel1. The debris can be seen at the bottom of the figure. At the time this photograph was taken the road had been repaired and some debris had been cleaned up.

A landslide in the residual soil cover is shown in Figure 57 . In this case all residual soil overlying the rock slid down over the road. Failures of this type were not common and most slope failures occurred by erosion in the colluvium below slopes.

Figure 58, taken about one year after the flood, shows two slopes along the road approximately 6 miles upstream from Drake along the North

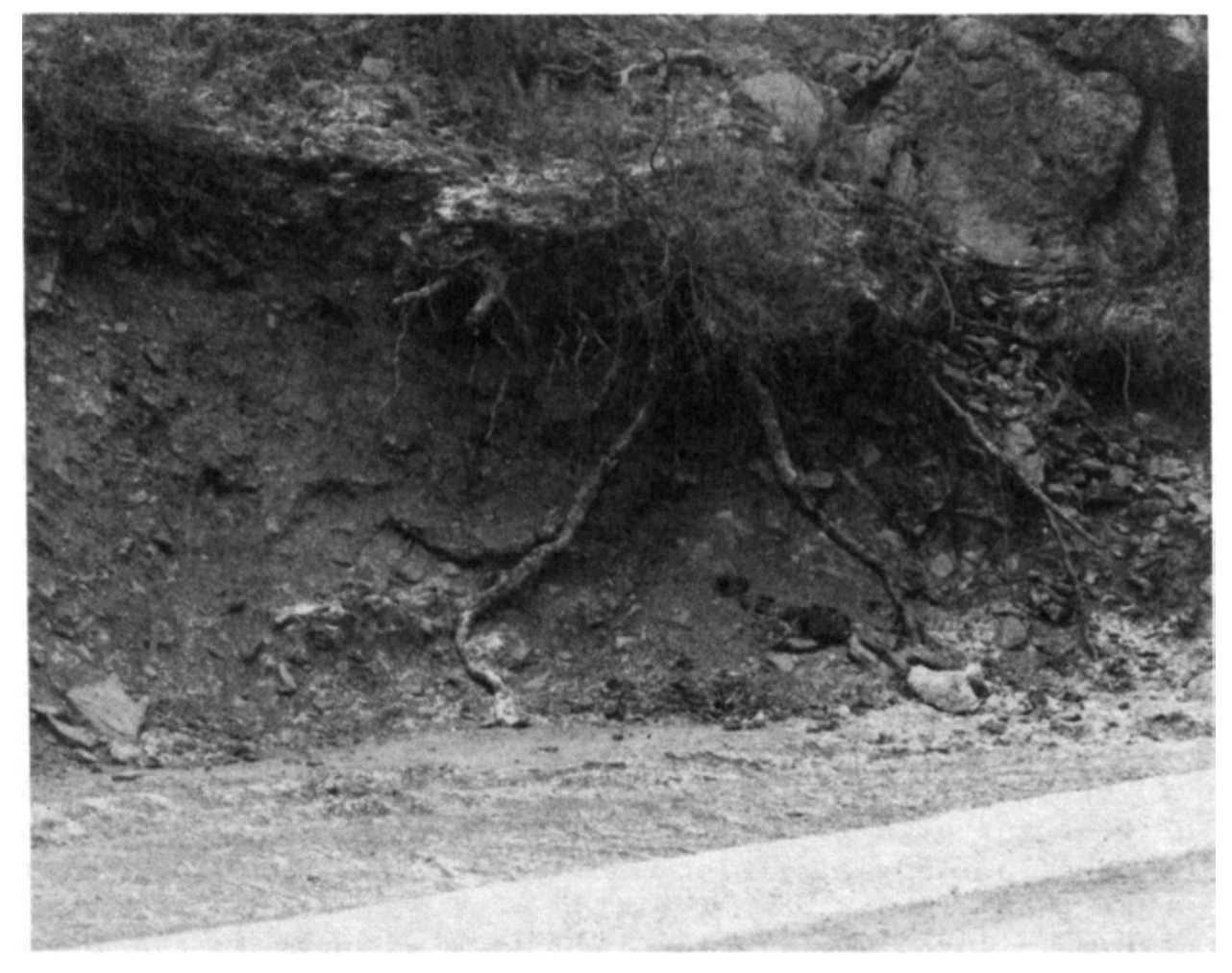

FIGURE 55 Root Zone of Soil Cover 


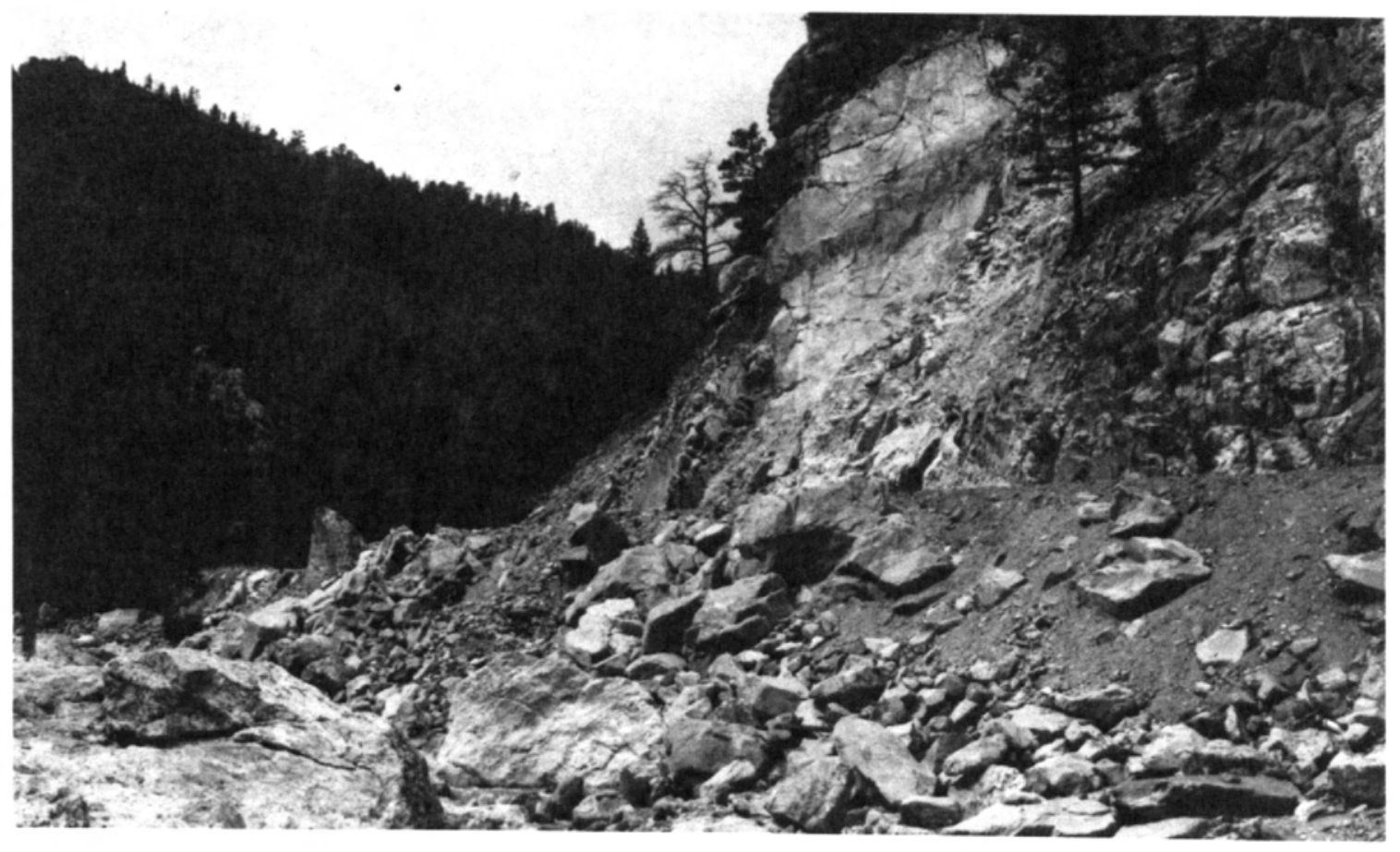

FIGURE 56 Rock Fall along Highway

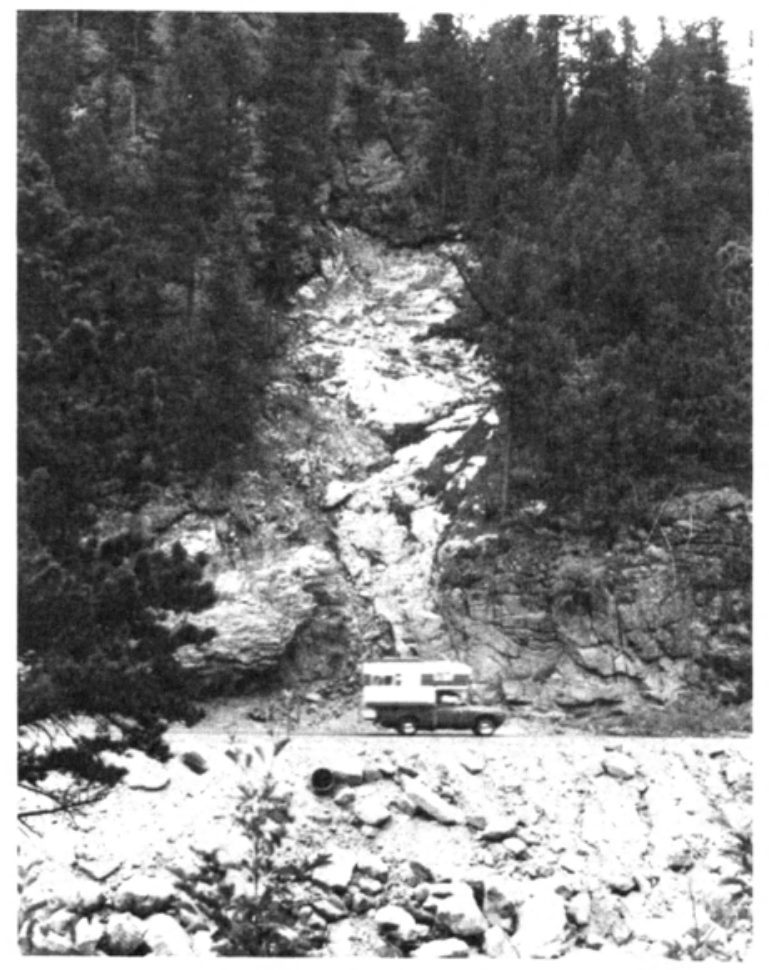

FIGURE 57 Lands1ide in Residual Soil 


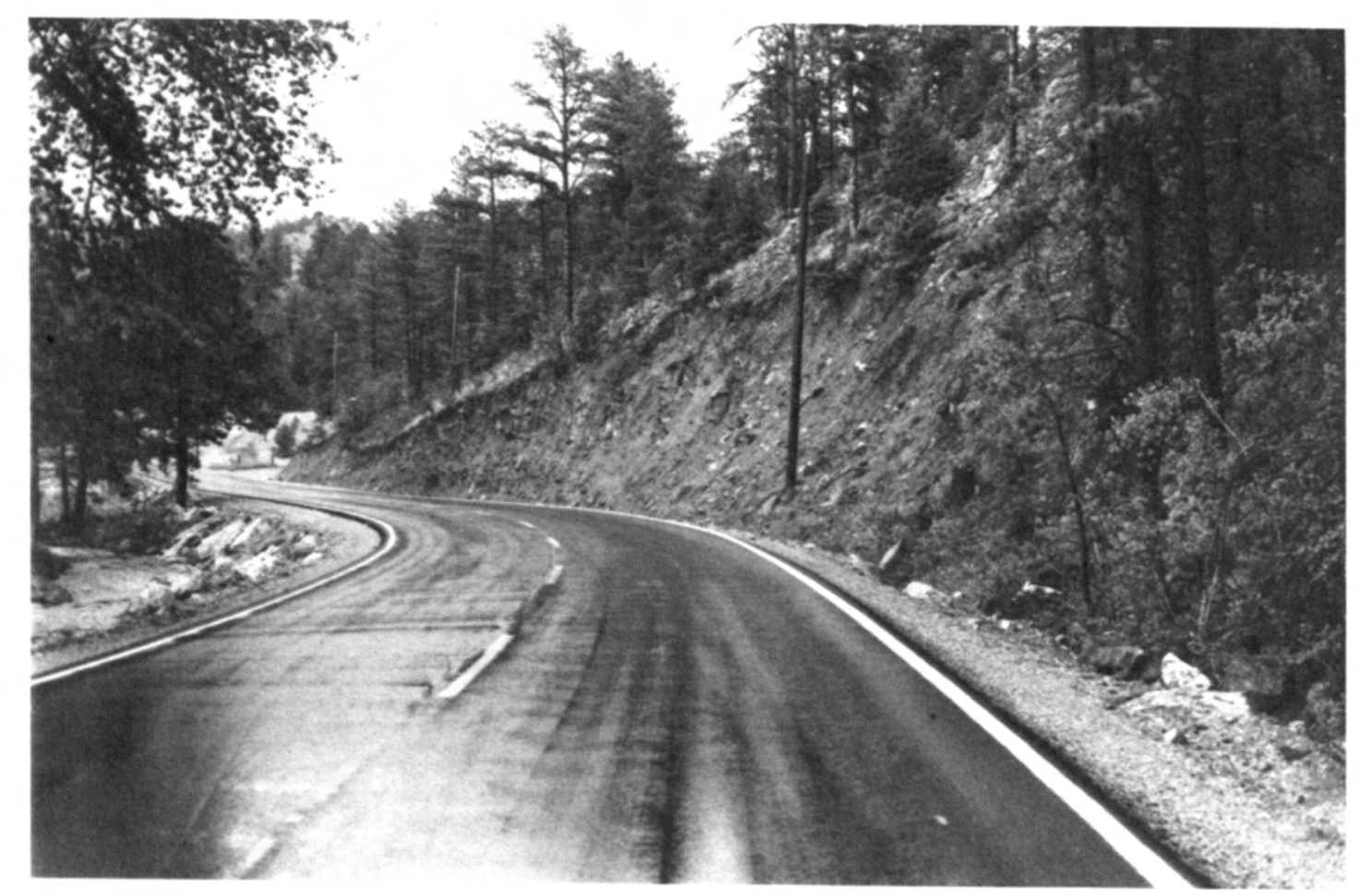

(a)

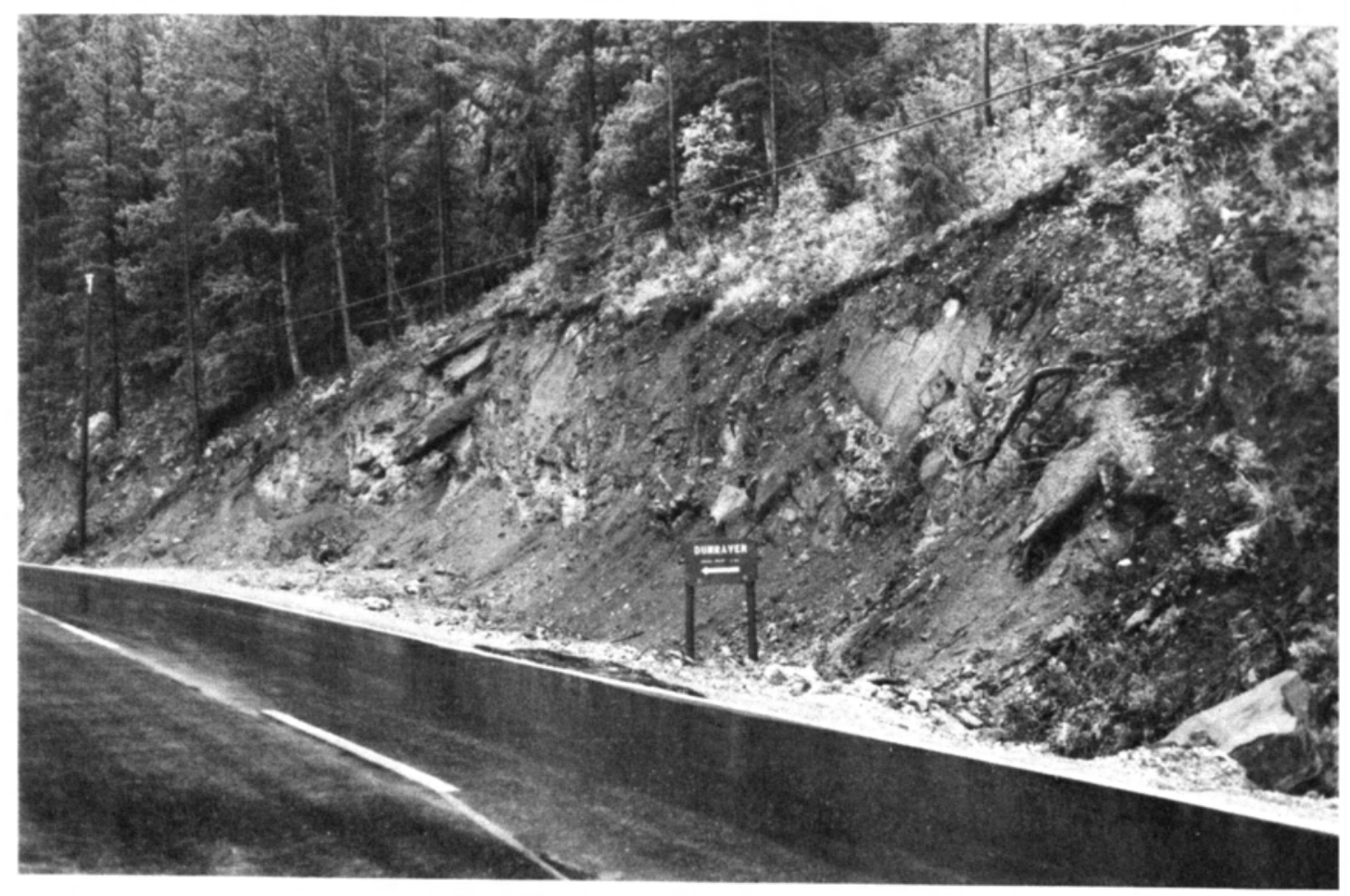

(b)

FIGURE 58 Slope in Colluvium along North Fork 
Fork; the soil was relatively thick in this area. It can be seen that the slopes left standing are relatively steep, particularly in Figure 58a, where a rather steep toe has been created by the clean-up crews. Of interest is the fact that the failure surfaces are all planar and the failures appear to have all been slab type landslides rather than rotational slope failures along curves or circular surfaces.

Figures $59 \mathrm{a}, \mathrm{b}$, and $\mathrm{c}$ show an area, about one mile long, about 3 to 4 miles upstream from Drake in the Big Thompson canyon. A large slope failure also occurred near Glen Comfort. Figure 60 is a composite photograph showing most of the length of that failure.

In the above slide areas the soil was thick and failures appear to have been induced by erosion along the streambank. Comparison of photographs taken in March 1977 and June 1977 indicate that sloughing is continuing on these slopes. The upper root zone of soil is clearly evident in Figures 59 and 60 . The upper soil cover is continuing to slough off exposing more of the upper part of the remaining slope. It is expected that movement of the slope will continue for a considerable time after the flood.

The soil and rock debris at the bottom of the slides was deposited sometime after the flood. River flows in the year after the flood have been abnormally low and the material at the toes of the slopes continues to accumulate. In subsequent periods of high flow this material may be

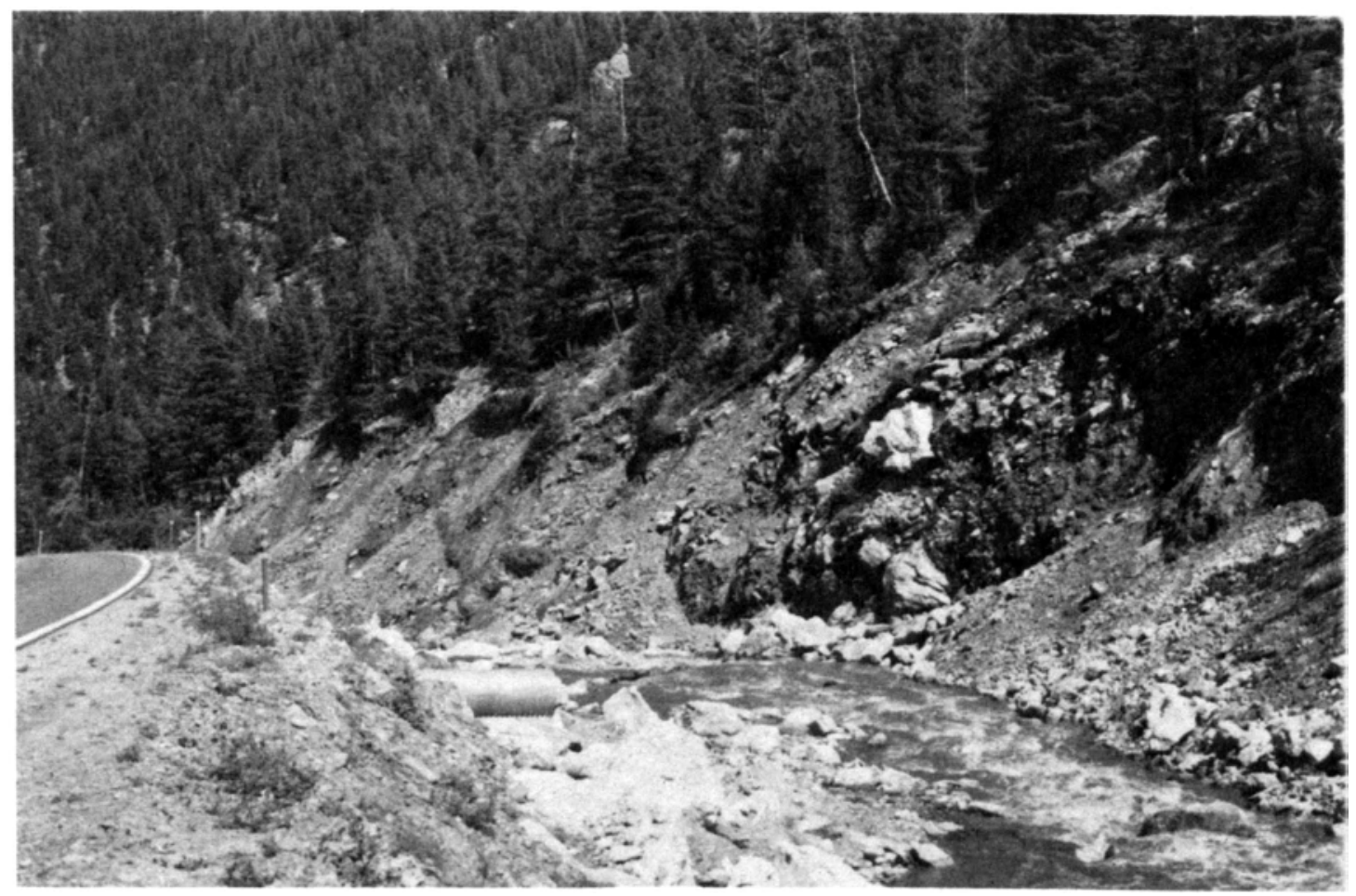

FIGURE 59a 


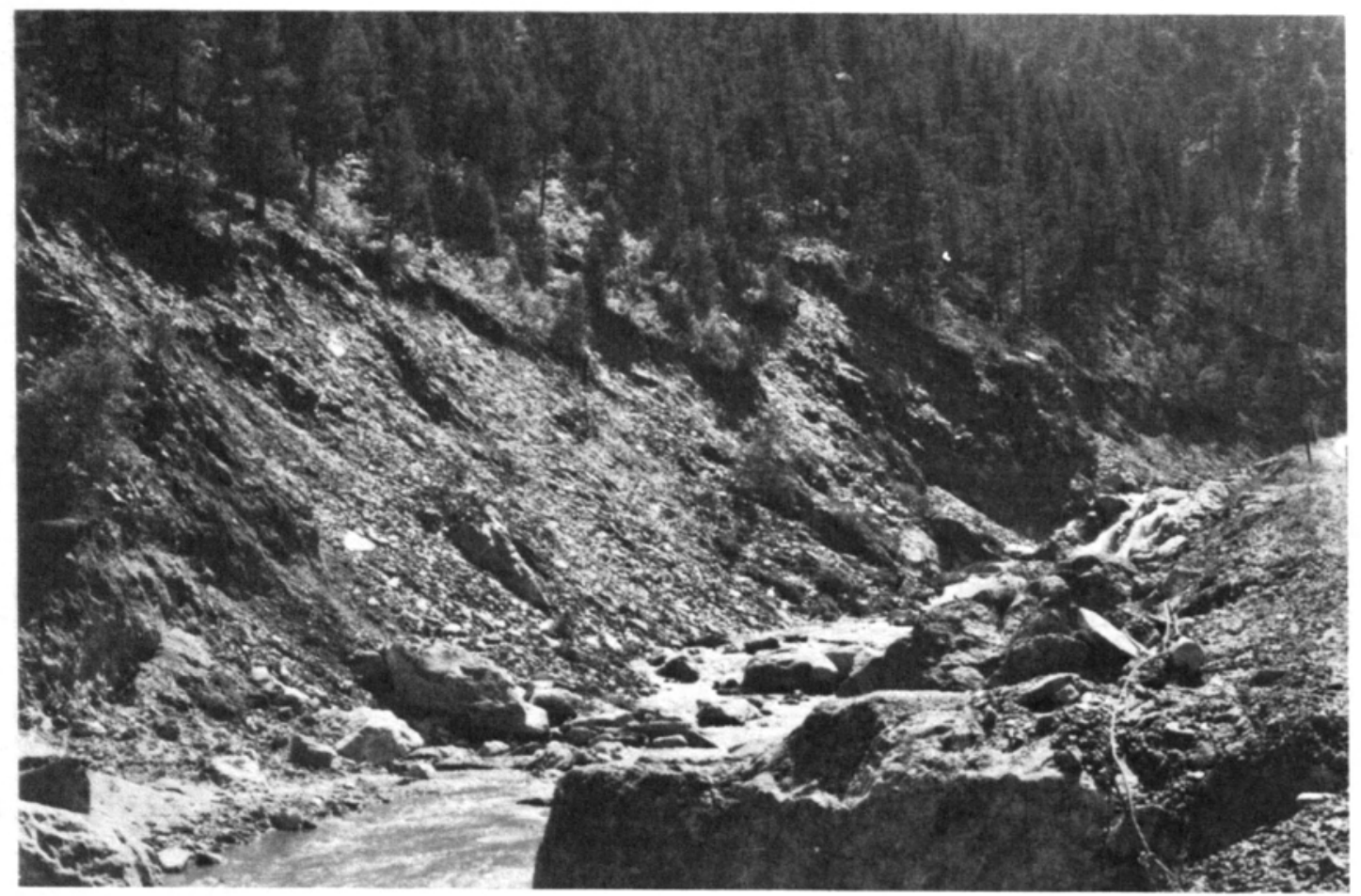

(b)

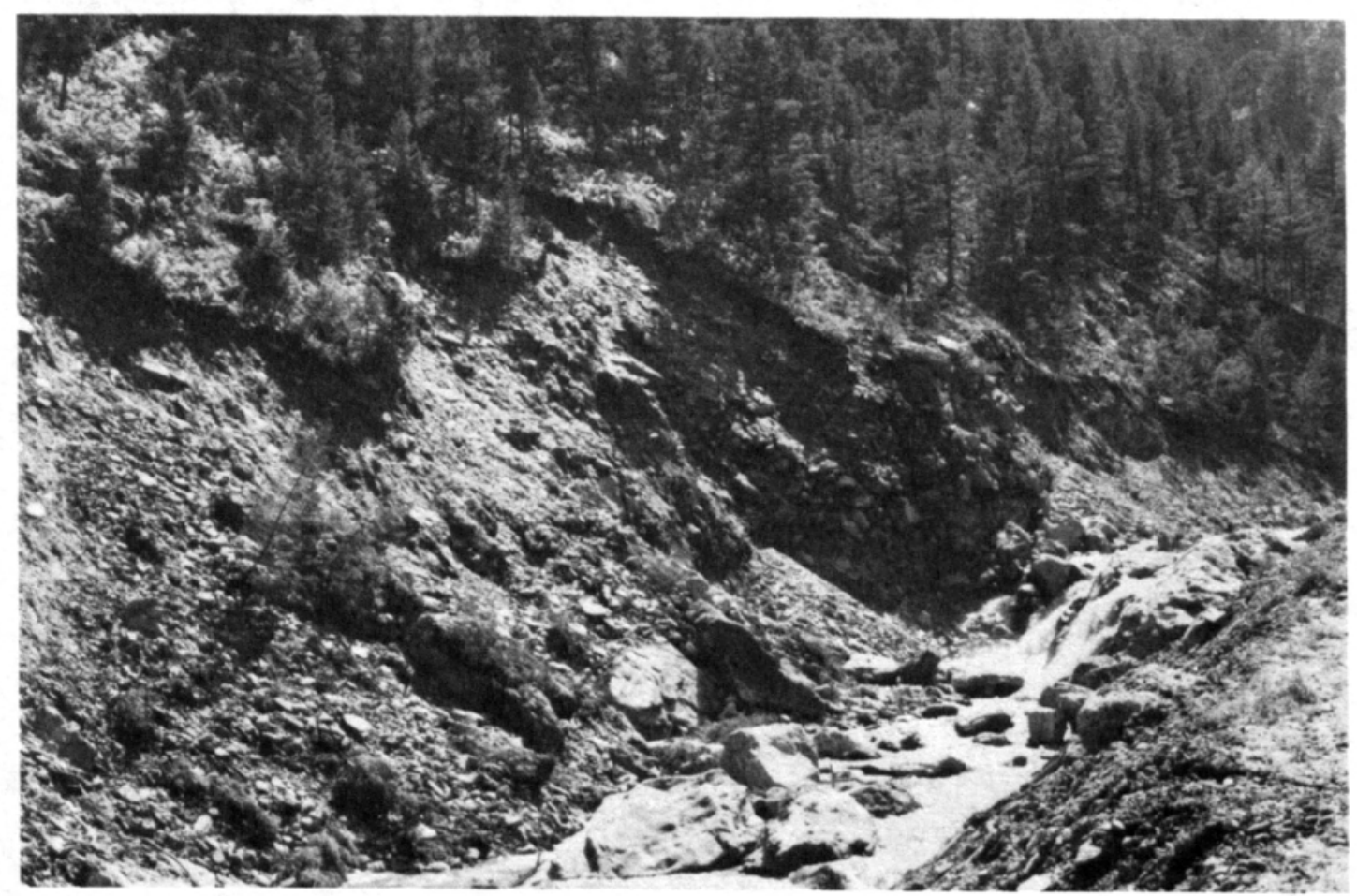

(c)

FIGURE 59 Slope Failure in Colluvium along Big Thompson River Approximately 3 to 4 Miles west of Drake 


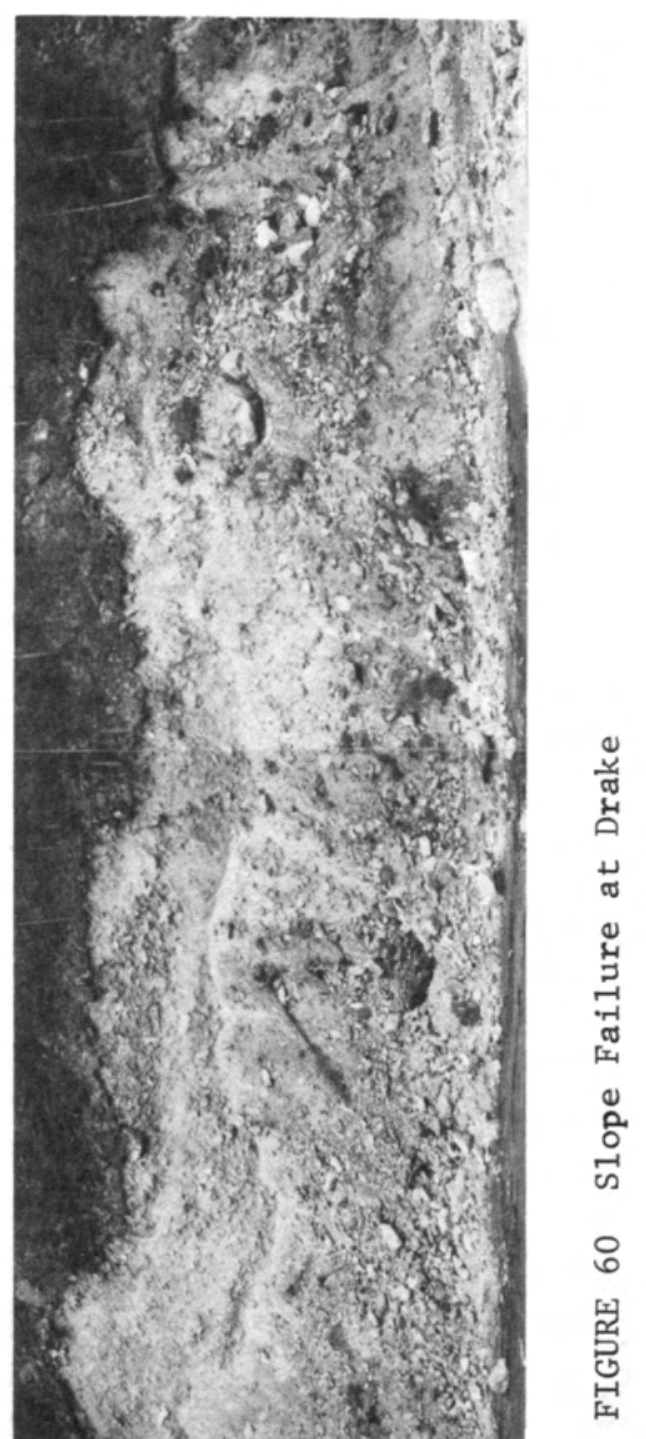

范 
washed out and the slope will continue to move. In this way, long-term progressive failure of these slopes may be expected to continue for several years after the flood; also, the steepness of the remaining banks may result in accelerated creep taking place due to increased stresses. Although the steepness of the slopes indicates that some cohesion must exist, the soil appears to have a high content of granular soil. It is rather uncertain therefore, whether or not the soil would be susceptible to creep failure.

An example of short-term progressive failure is shown in Figure 61. The failures shown therein were not evident on aerial photographs taken four days after the flood but were observed two days later. Numerous small slope failures were also evident along the entire length of the canyon. They were all of the same general nature as those discussed above but of considerably smaller magnitude. These slope failures were not confined to the main canyon but could be observed in draws and smaller side canyons as well.

The effects of these slides ranged from road blockages that had to be cleared to hazards imposed on buildings by the undermining of foundations and by the potential for debris to fall on structures.

Another class of slope failure includes the erosion of debris fans where they existed in the floodplain. Figure 62 shows an area in Olympus Heights near Estes Park along Dry Gulch; the large amount of

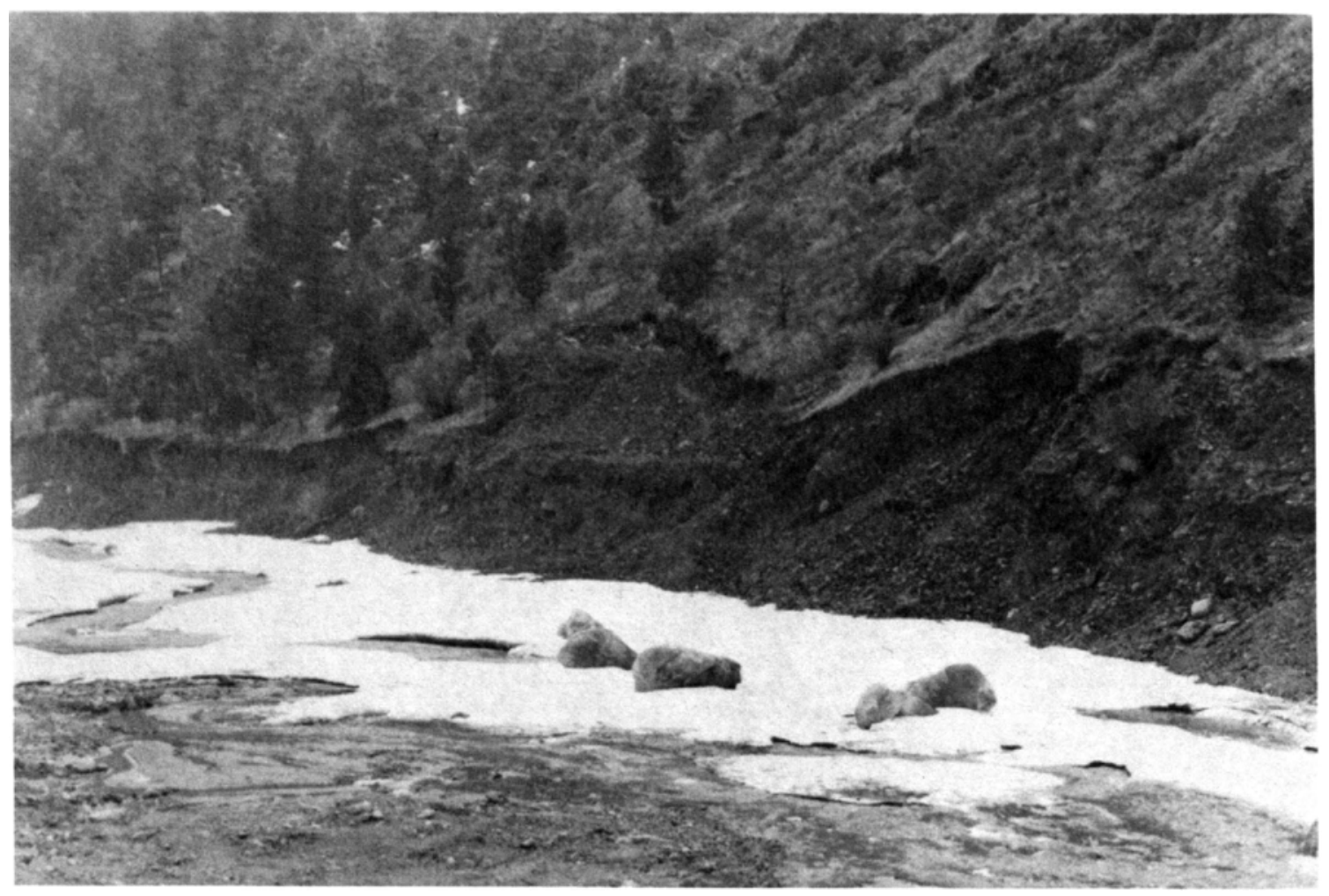

FIGURE 61 Slope Faflure Formed about One Week after the Flood 


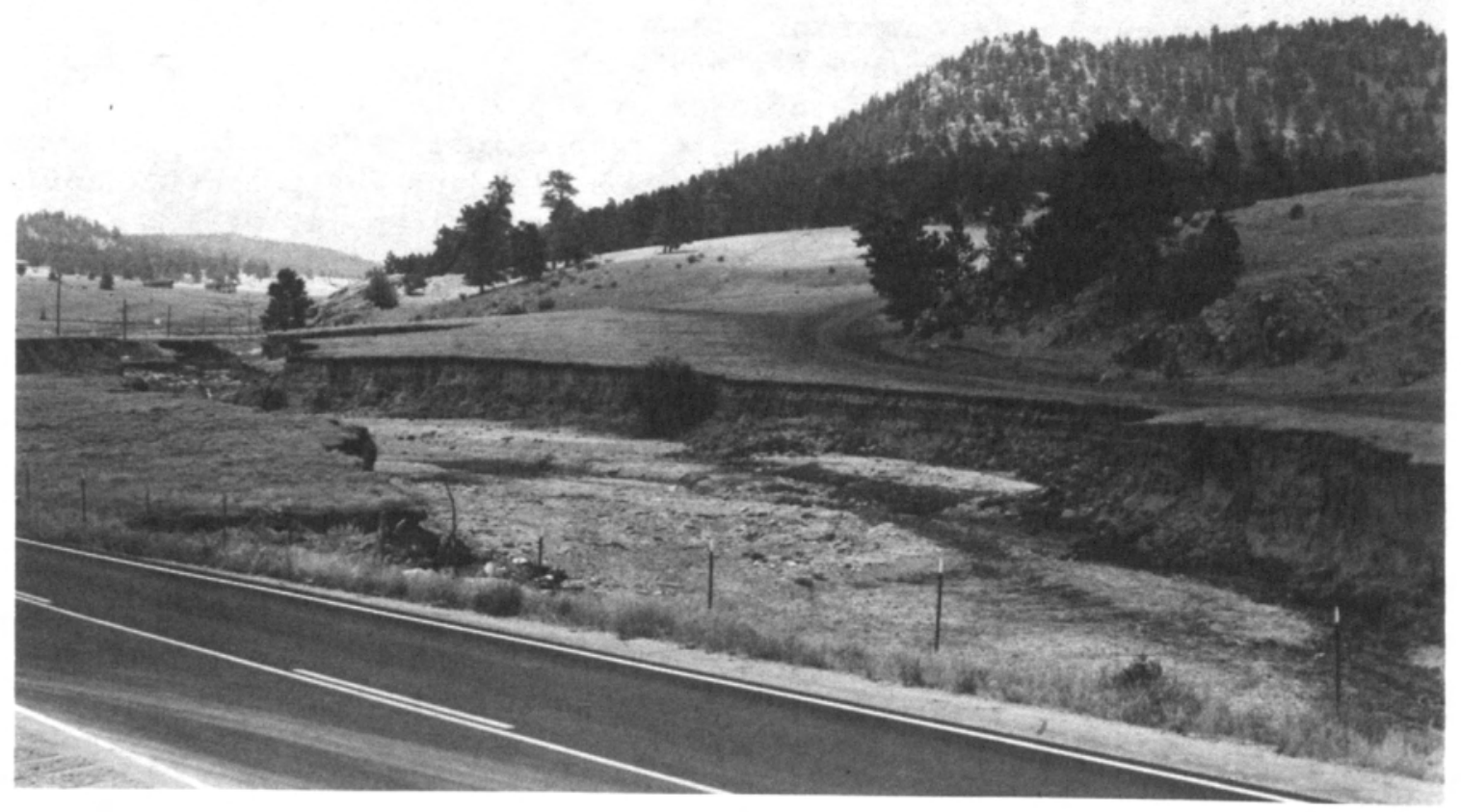

FIGURE 62 Erosion along Dry Gulch

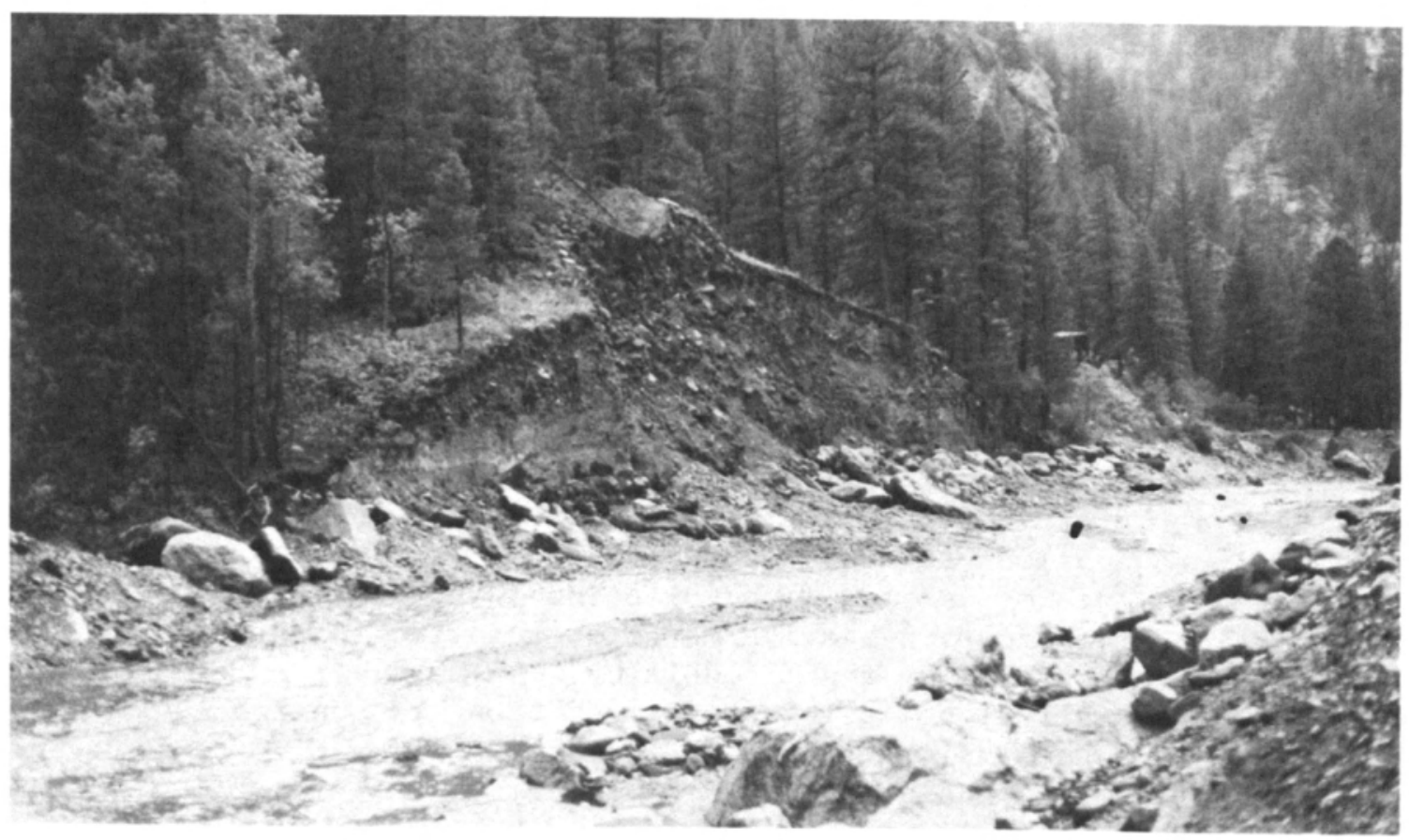

FIGURE 63 Erosion of Debris Fan 
erosion is evident. Figure 63 also shows a debris fan eroded by the Big Thompson river. The remaining slope is very steep and may be expected to exhibit progressive failure.

An example of damage to structures by erosion of a debris fan appears in Figure 52. The importance of geological hazard analyses in zoning and floodplain management is emphasized by the potential for damage to occur outside of the floodplain due to slope failures.

\section{Embankments and Dams}

In the canyon, two dams or diversion structures failed. Whether the cause of the failure was overtopping or foundation erosion cannot be determined with certainty. Figure 64 shows the remains of the Loveland Hydroelectric dam.

One potentially drastic occurrence is illustrated in Figure 65, showing the Olympus dam in Estes Park. The light colored zone of rock at the toe of the dam was eroded by the floodwaters flowing down Dry Gulch in the foreground of the photograph. Olympus dam is 47 feet high and is located a short distance above the mouth of the Big Thompson canyon in Estes Park. If that dam had failed the effects of the flood would have been much worse.

Other embankment failures have been discussed previously in connection with highway failures. In summary, embankments may be particularly susceptible to erosional forces. The use of coarse riprap on embankments located where erosion may be problematical should be an important consideration.

\section{Conclusions}

1. Highway embankments located near the streambed were particularly susceptible to erosion.

2. Localized pavement failures resulted from scour on inside drainage ditches along roadways.

3. Backfill at bridge approaches was particularly susceptible to erosion.

4. Masonry and pier foundations were more susceptible to flood damage than concrete wall foundations.

5. Much structural damage resulted from structures being floated off their foundations and washed downstream.

6. Research into methods of flood-proofing structures is needed.

7. Erosion of foundation-bearing material resulted in failures of structures outside of the floodplain.

8. Numerous small slope failures occurred along the entire length of the canyon and inside canyons and gulches.

9. Slope failures consisted of:
a) rock falls
b) landslides in residual soil cover
c) erosion of colluvial slopes
d) erosion of debris fans 


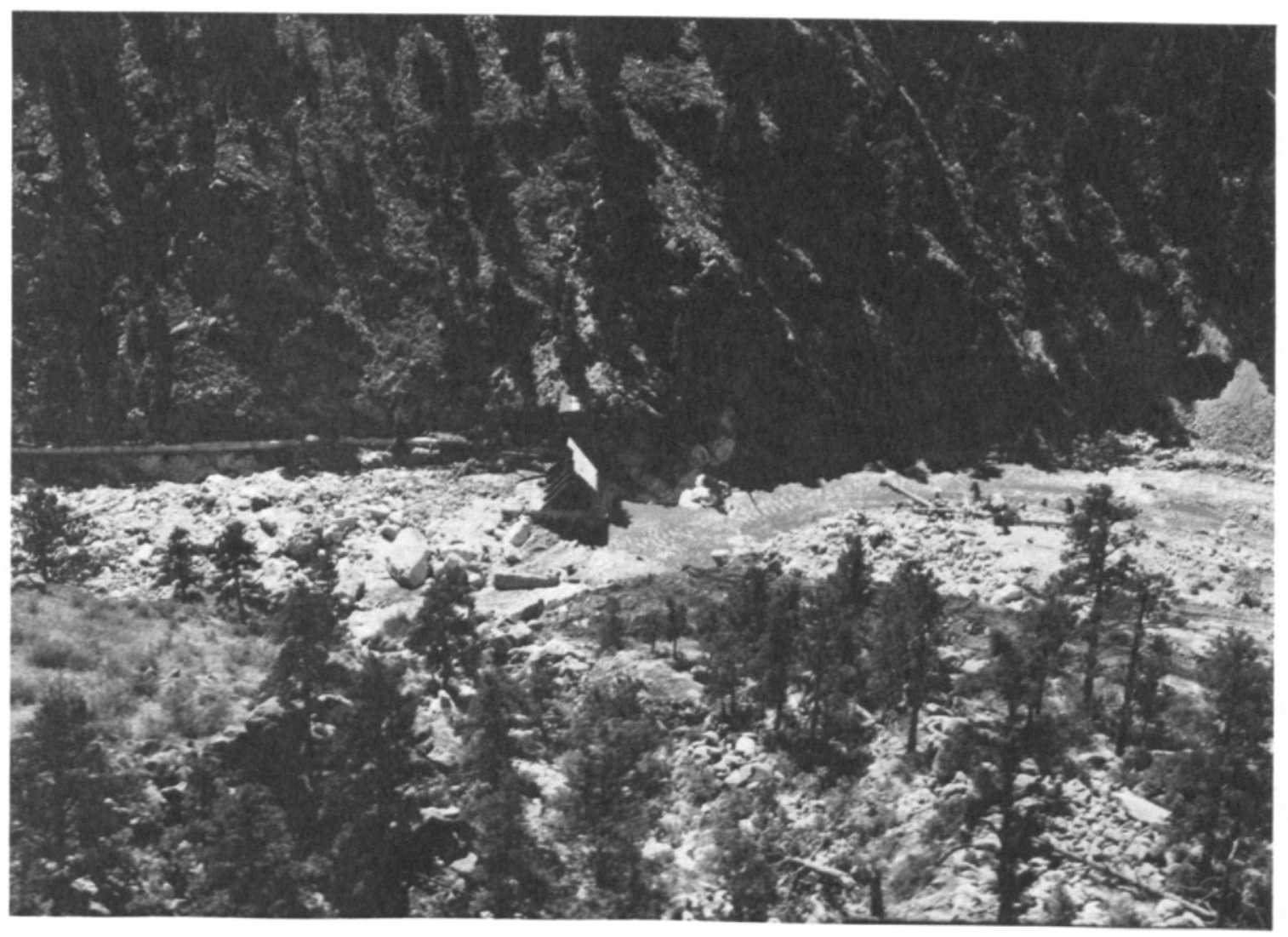

FIGURE 64 Remains of Loveland Hydroelectric Dam

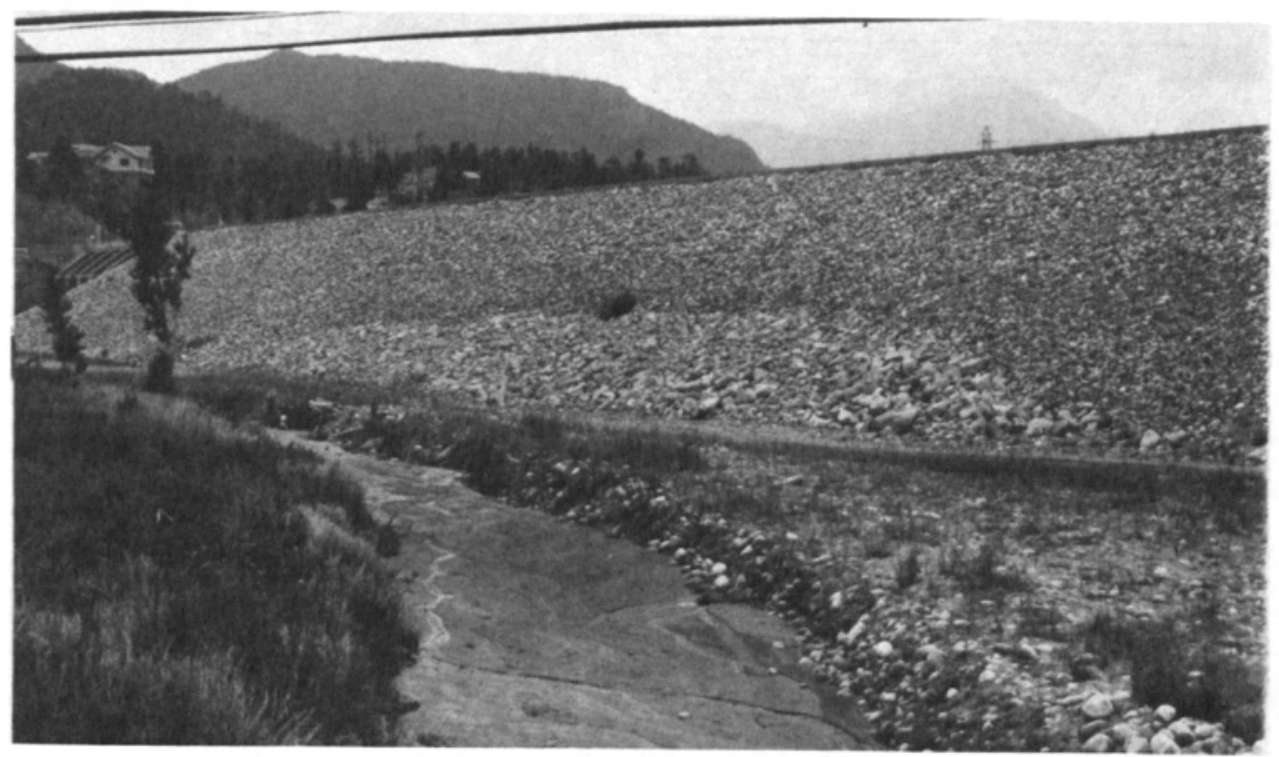

FIGURE 65 01ympus Dam 
10. Slope failures were caused by:
a) erosion of the toe of the slope
b) seepage forces
c) creep failure of slopes caused by erosion
d) slope steepening during clean-up operations
e) long-term instability resulting from vegatation removal

11. Embankments and dams were damaged by erosion. Design of embankments should include precautions to minimize scour at the toe.

12. Geologic hazard reports should be required prior to construction in or near the floodplain.

\section{DAMAGES}

The Big Thompson flash flood took a tragic toll of life and property. A total of 139 people lost their lives in the flood with 4 still missing. Economic losses alone exceeded $\$ 41,000,000$. The once beautiful valley was reshaped by the rushing waters, leaving white-brown sediment covering the floodway. Large numbers of trees which once shaded the valley were either severely damaged or swept away.

TABLE 4

Summary of Direct Economic Losses in the Big Thompson Kiver Flood

\begin{tabular}{lr}
\multicolumn{1}{c}{ (U.S. Corps of Engineers, 1976) } \\
\hline \multicolumn{1}{c}{ ITEM } & \multicolumn{1}{c}{ LOSS $(\$)$} \\
\hline Government Clean-up & $1,611,000$ \\
Emergency Efforts & 656,700 \\
Road Repairs & $19,120,000 *$ \\
Structural Damages & $13,169,500 *$ \\
Personal Property & $5,036,000$ \\
Employment Losses & 115,500 \\
Damages to Public Facilities & $1,634,000$ \\
not elsewhere considered & 96,400 \\
Emergency Social Assistance & \\
& $\$ 41,439,100$ \\
\hline
\end{tabular}

*Updated from previous USCE-C estimates by Toups Corp. (1977). 


\section{Loss of Life}

On the night of the flood, the canyon was crowded with an estimated 4,000 people consisting of the usual mixture of campers, tourists, and residents. When the flash flood hit, many of the people had little or no warning. Others who had been warned of the danger failed to move because they felt no threat from the timid stream. Many people who attempted to drive to safety were swept away as the roadway was eroded beneath their vehicles. Eyewitnesses reported cars floating downstream with their headlights shining, and people inside pleading for help. Some people spent the night on roof tops, or whatever high ground could be found. Of the 139 people killed, 98 were visitors to the canyon with 64 coming from portions of the United States outside Colorado (Toups Corp., 1977).

\section{Structural Damages}

During the night of the Big Thompson flood almost 500 structures were damaged to some extent: 242 structures were damaged less than $50 \%$, and 252 were damaged more than $50 \%$ (U.S. Corps of Engineers, 1976). Damage was mainly concentrated along the valley floor, although some damage to structures along higher ground were reported due to landslides, rockfalls, and other mass wasting processes. Destruction came mostly from battering by debris and materials moved by the stream. Figure 66 shows a house where the stream hurled a tree through the upstream wall.

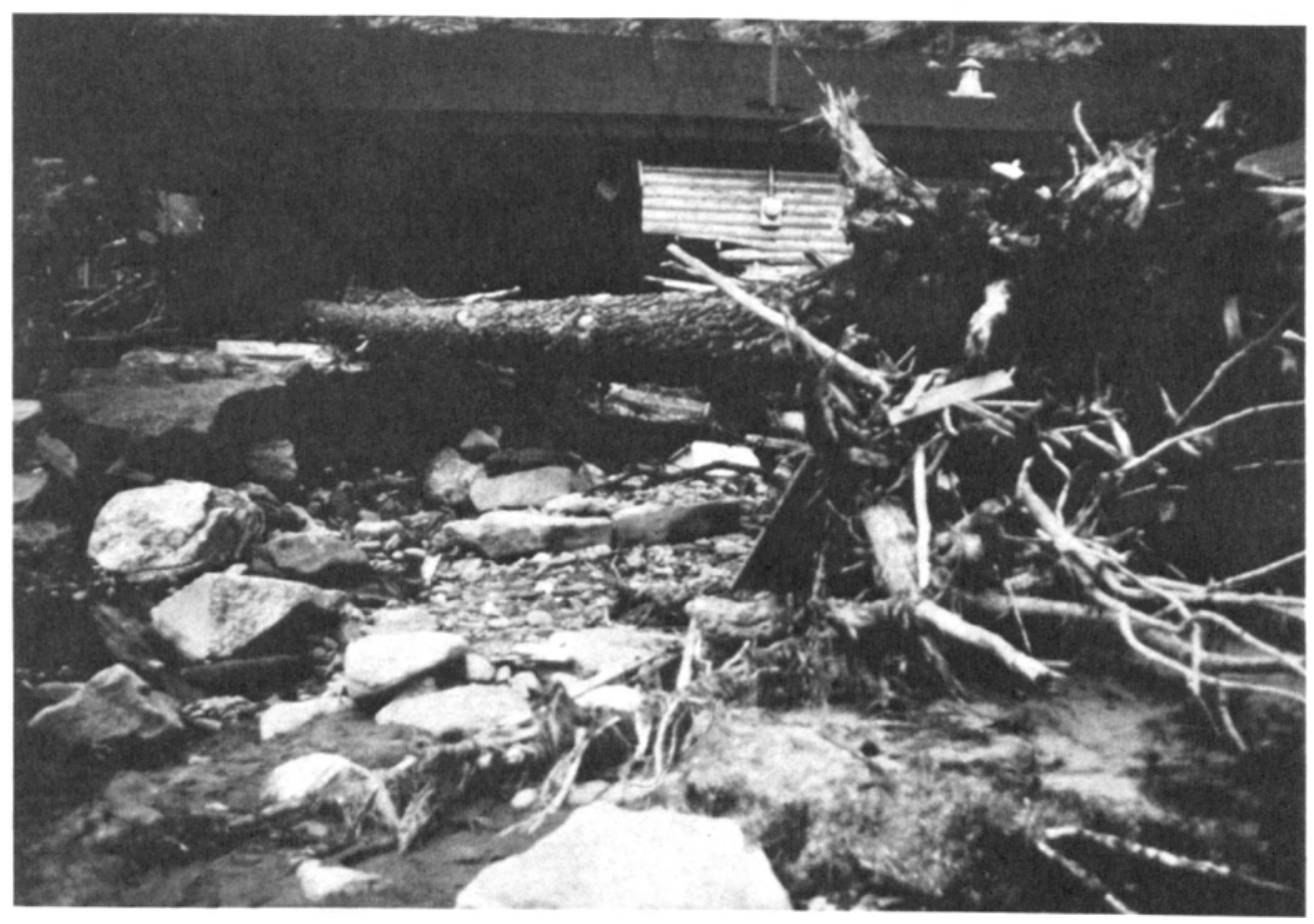

FIGURE 66 House Damaged by Tree Hurled through Upstream Wall 


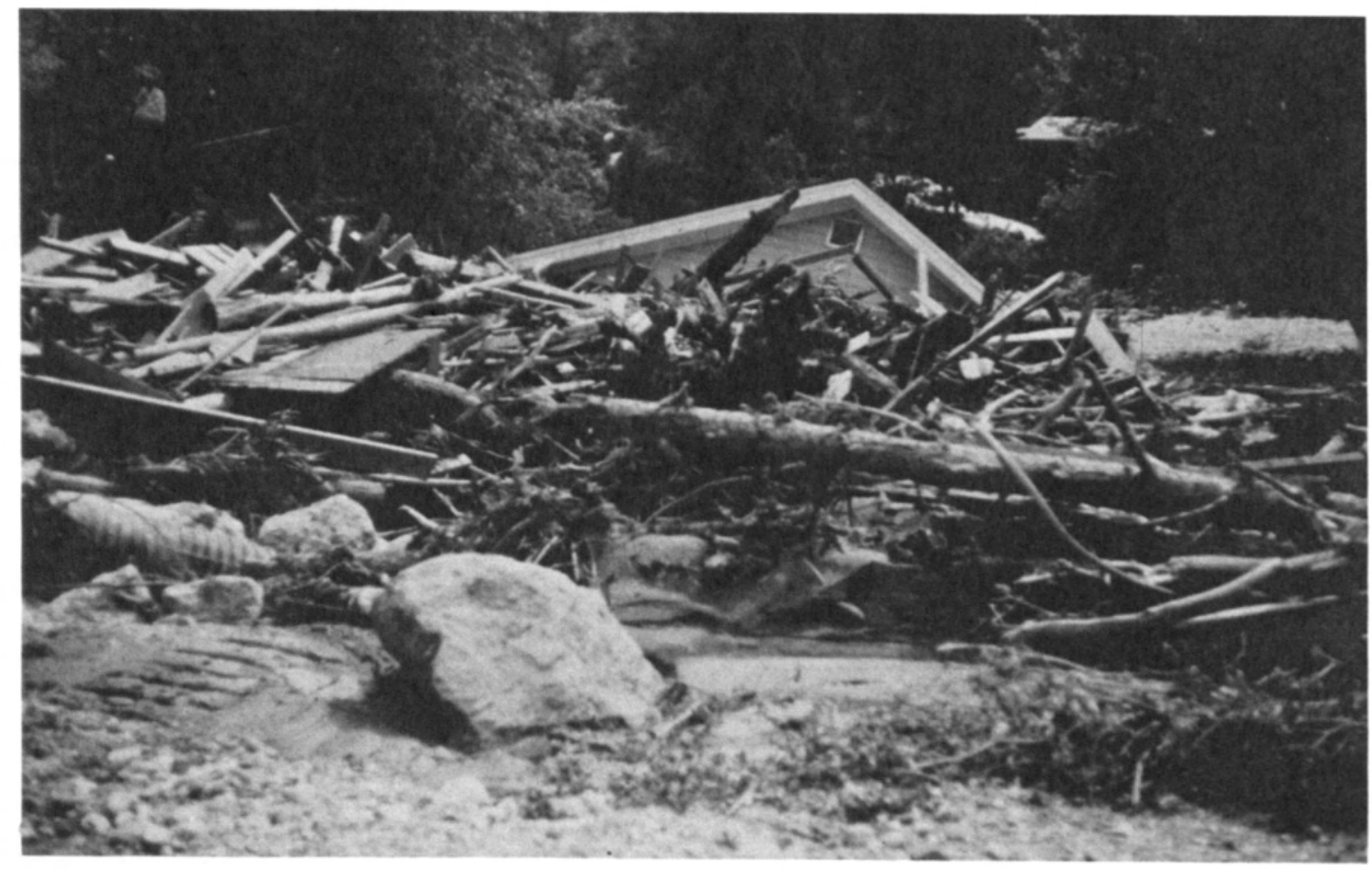

FIGURE 67 House near Drake Flattened by Boulders and Debris

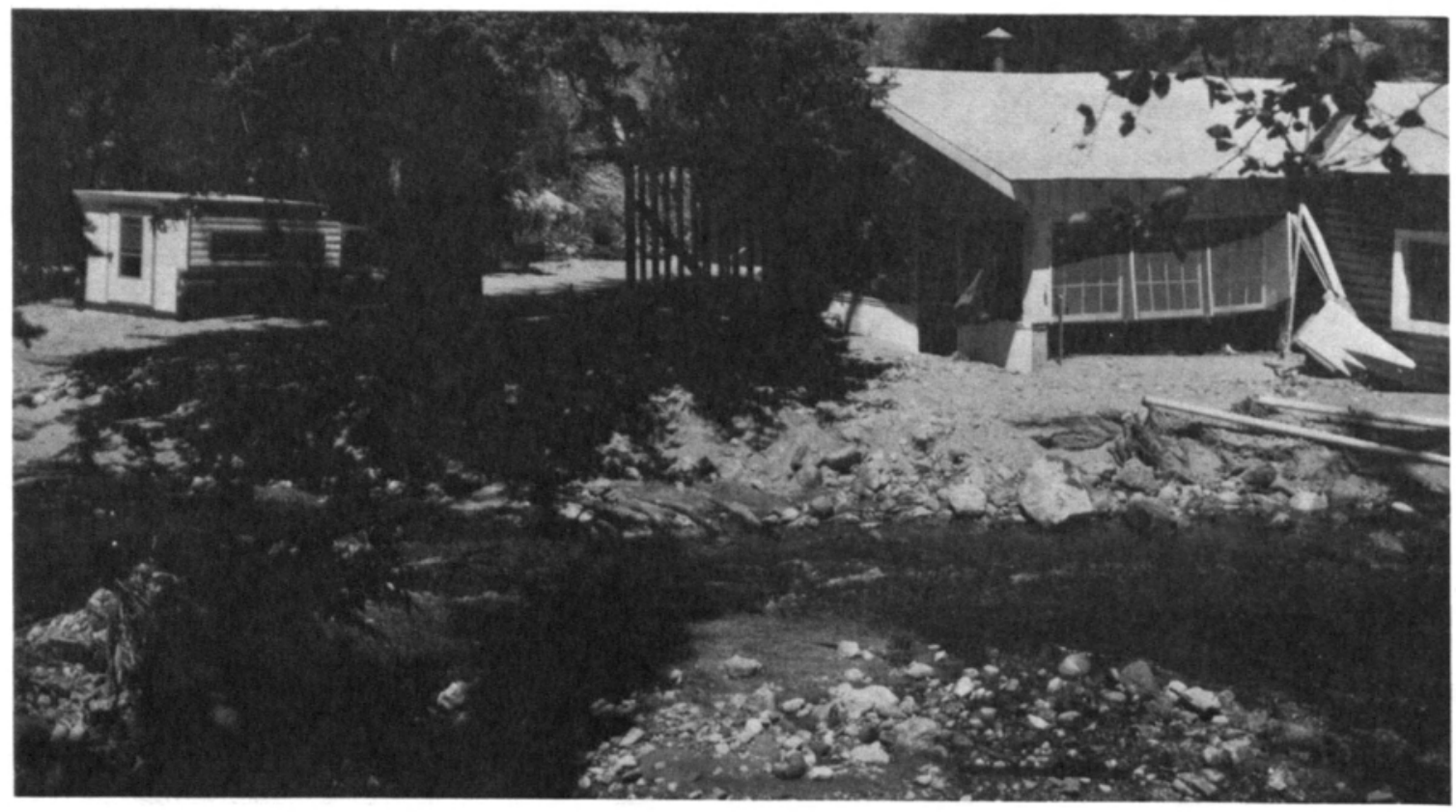

FIGURE 68 Sediment Deposited around House along West Creek 


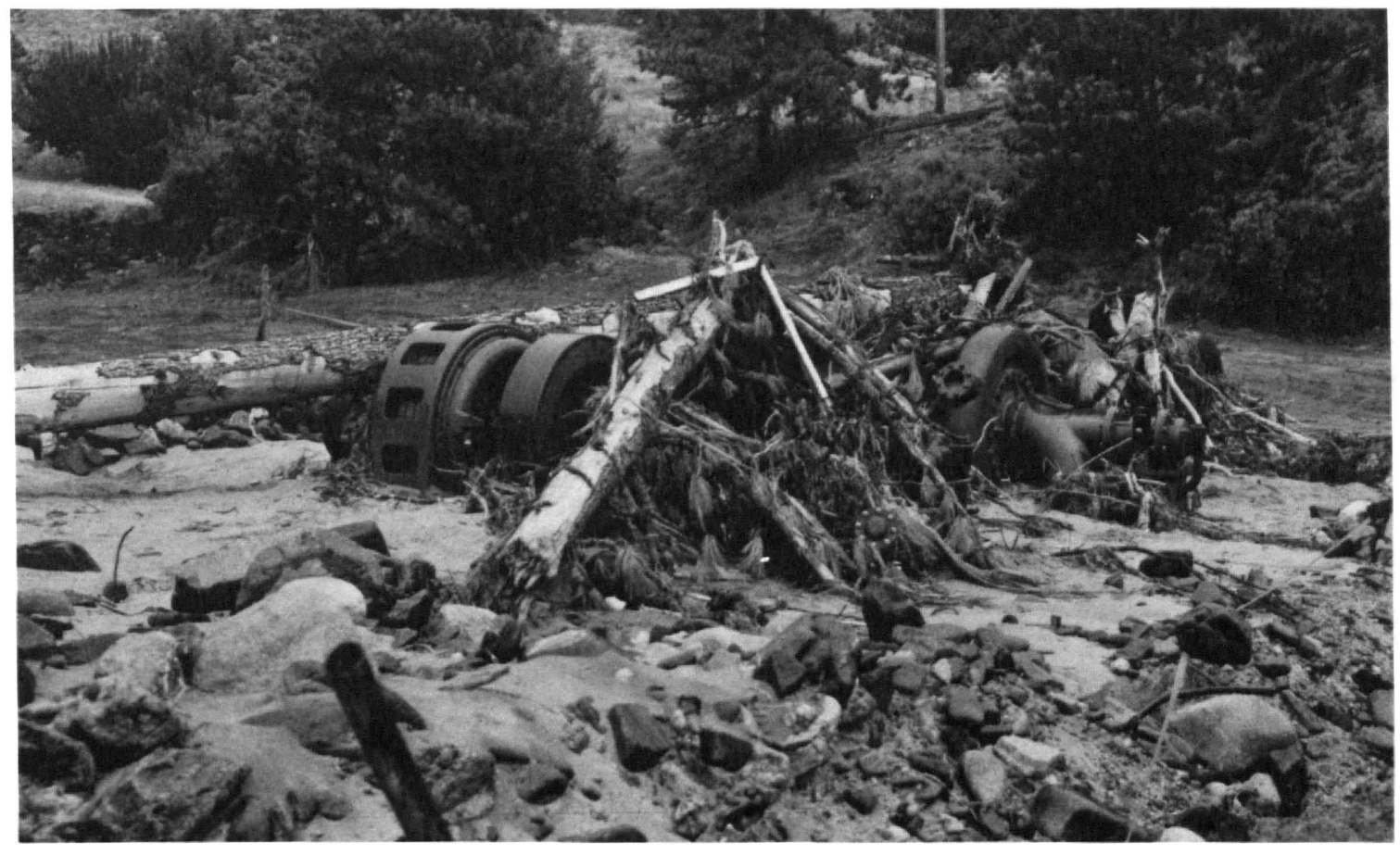

FIGURE 69 Remains of Loveland Power Plant at Loveland Mountain Park

Figure 67 shows a house near Drake that was flattened by boulders and debris. Other damages resulted from structures being buried by sediment (Figure 68). Floodwaters demolished the Loveland Diversion Dam and Power P1ant (Figures 48, 64, and 69). Damage to these structures was estimated to be $\$ 2,500,000$. The masonry structure which protected the Loveland Power Plant completely disappeared--caried away by floodwaters --leaving only the exposed turbines. One of the more unusual structures to be damaged was the U.S. Bureau of Reclamation siphon which carried the Charles B. Hanson Canal across the canyon. That night a floating structure hit and pushed out a pier supporting the siphon, causing it to collapse under its own weight. Figure 70 shows the canyon opening minus the siphon and Figure 71 shows the battered siphon deposited downstream. Repair costs for the siphon were approximately $\$ 300,000$.

\section{Damaged Roadways}

The majority of the economic loss from the flood was related to the roadways that paralle1 the stream. Damage was estimated at $\$ 19,120,000$. About 9.5 of the 23 canyon miles of U.S. Highway 34 were washed out, and an additional 10.5 miles were sufficiently damaged to require repair. Repair cost was estimated at $\$ 16,500,000$. Approximately 10 miles of Glen Haven Road, which parallels the North Fork from Glen Haven to Drake, and about 4 miles of Devils Gulch Road along Devils Gulch were also washed out. Numerous access roads, both public and private, were also severely damaged. Roadway damage usually occurred at two locations: 


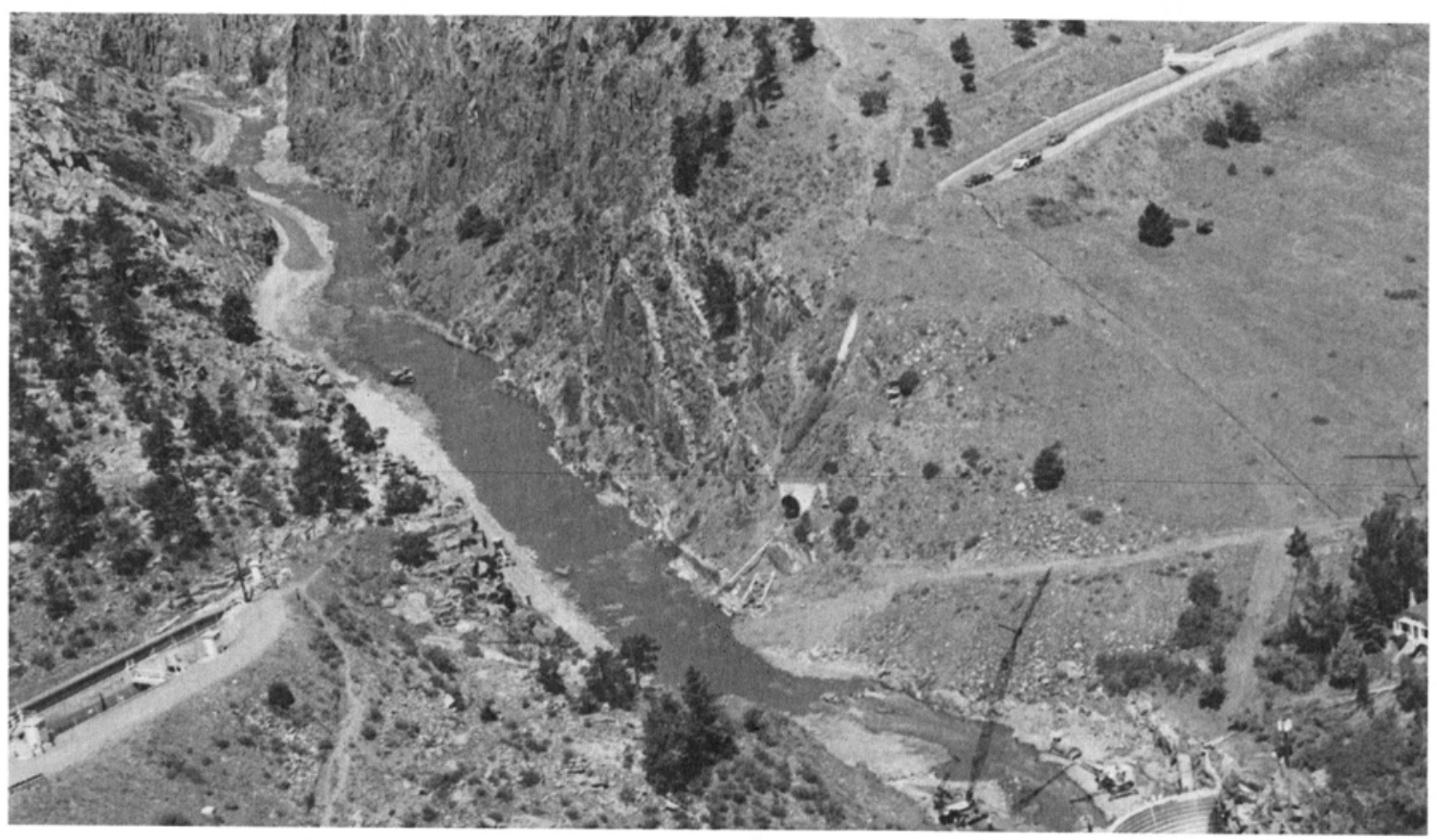

FIGURE 70 Siphon Support Structure and Feeder Canal Located at the Mouth of the Canyon

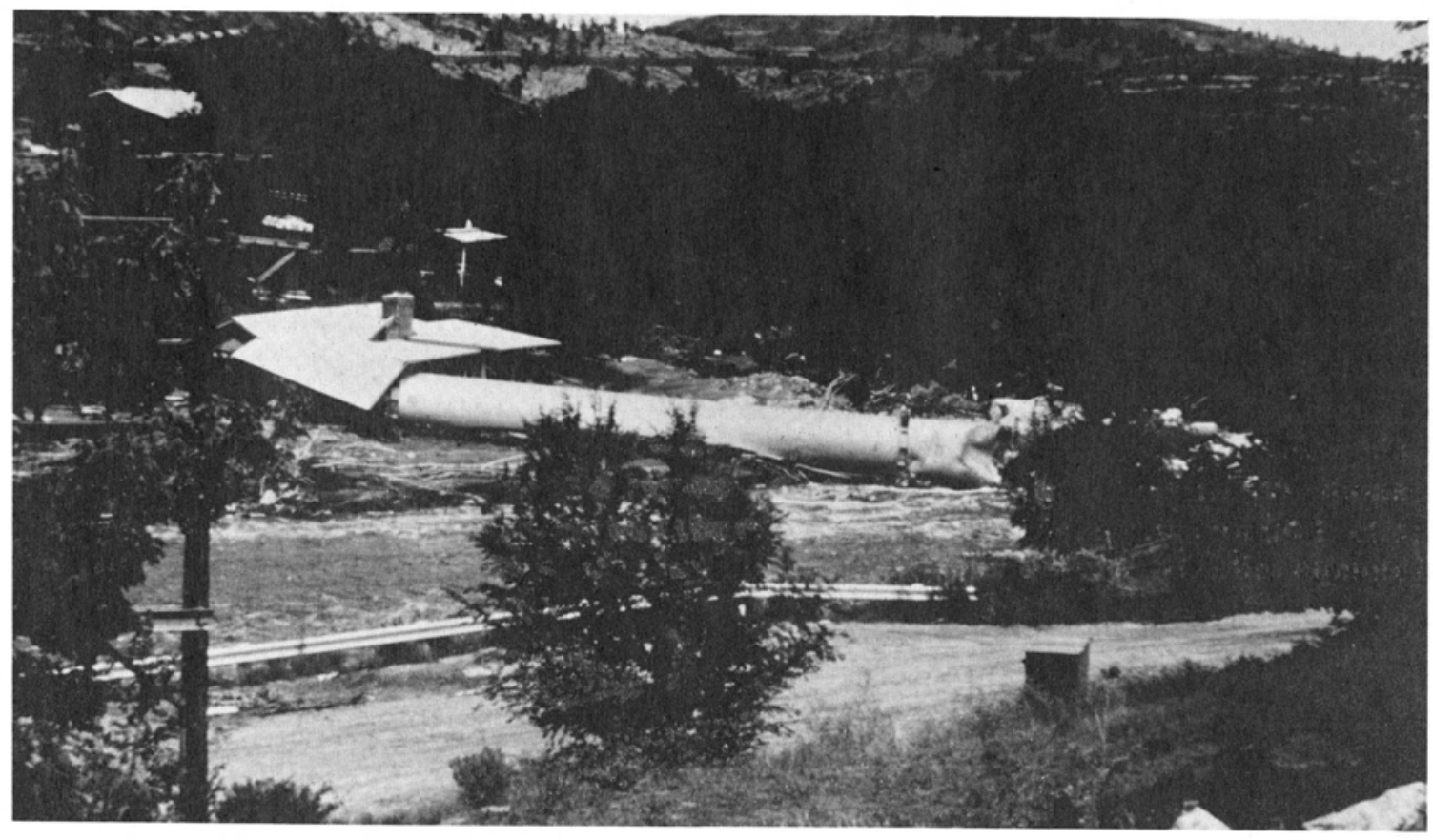

FIGURE 71 Remains of the U.S. Bureau of Reclamation Siphon 
along narrow sections of the valley where the road embankment constricted the channel, and along the outside of bends (Figure 36). A total of 42 bridges gave way to the floodwaters; of these, 18 were lost along the Big Thompson river and 24 along the North Fork (Toups Corp., 1977).

\section{Commercial Losses}

Businesses along U.S. Highway 34 experienced revenue losses during the months of August and September while the roadway was being repaired. Only $10 \%$ of the commercial property ( $\$ 640,000$ damage) within the canyon was damaged during the flood, but the closing of the roadway cut off the flow of tourists. Also affected were commercial interests in Loveland and Estes Park that relied on the business of tourism along U.S. Highway 34 to Rocky Mountain National Park. Estimates of revenue losses indirectly related to the flood exceeded $\$ 5,000,000$ (Toups Corp.)

\section{Damage to Canyon Environment}

Not all losses from the flood can be measured economically or in terms of dollars and cents. The once beautiful valley which supported lush vegatation along the canyon floor was covered with gray-brown sediment. Many of the trees were swept downstream or severely damaged by the moving sediment. Figures 22, 23, 24, 30, and 32 show views of the canyon before and after the flood of 1976. The once clear river is now murky, as fine sediments and deposits from the upper reaches slowly transport downstream. Coldwater fishing, an important recreational attraction prior to the flood, was destroyed. In addition, the shifting unstable streambed could discourage the redevelopment of coldwater fishing for years to come. In time, the vegatation will cover the sediment, the trees will grow back, and the stream will return to its original beauty, but for now these aspects will be a sad reminder of the flood.

IMPACT OF THE FLOOD

\section{Floodplain Zoning}

Prior to the 1976 flood, people were not conscious of the hazards and risks present along mountain streams such as the Big Thompson. Acceptable levels of risk were based on experience with the river, and historically the Big Thompson had never experienced serious flooding. The river had not even left its banks in the 20 years since the 0lympus Dam was completed. As a result, development moved into the floodplain and, in some places, continued up to the banks of the river.

The Big Thompson flash flood changed the acceptable level of risk. Local governments no longer felt that floodplain areas were suitable for development and that, for the good of all, these areas should be zoned to limit development. Consequently, immediately following the flood the 
Larimer County Planning Commission declared a moratorium on the repair of all structures within the canyon, damaged greater than $50 \%$, pending a Floodplain Information Study. This study, performed by Gingery and Associates, Inc., mapped the 100 and 500 year flood hazard areas. Following completion of this report, the Planning Commission adopted a building code which severely limited development in the floodplain (Larimer County Planning Commission, 1977). The code states that no new human habitation can be constructed within the 100 year floodplain. Structures damaged greater than $50 \%$ by flooding could not be repaired and enlargements to existing structures in this area were also limited.

Canyon residents were furious at the action. Many considered the flood a freak event which would not occur again for several hundred years. They could not understand why these restrictions were put on their property. It seems economic considerations had replaced the memories of that tragic night. However, their complaints were legitimate; property values had declined over $\$ 4,000,000$ according to the estimates of the county assessor (Toups Corp., 1977).

Because zoning has such an adverse impact on property values, floodplain information studies must be carefully prepared and accurately represent flood hazard areas. The accepted analysis techniques which simulate an event of a given return period may not be appropriate. Thses techniques break a stream into characteristic reaches and calculate discharges of $10,50,100$, and 500 year return periods for each reach. The discharges are calculated from a statistical analysis of streamflow data or from a hydrologic model which simulates runoff from frequency of rainfa11. Then a hydraulic routing model, simulating gradually varied flow, computes water surface profiles associated with each of the return periods. This analysis does not simulate the characteristics of mountain flash flooding, but instead simulates the characteristics of snowmelt floods. Flash floods are caused by intense rainfall concentrated over a small area of the basin. The resulting stream flow is considered rapidly varied flow. Furthermore, the flow carries vast amounts of sediment which may aggrade or degrade the channel several feet. The final facet could cause significant changes in the water surface profiles. Existing hydrologic and hydraulic models can effectively predict the water surface along the vertical channel changes. The prediction of lateral movement is beyond the practical scope of these models, but this movement is of minor importance at most locations in the narrow canyon. Model parameters for rare events are generally assumed to be the same as the largest flood event. This practice is not uncommon and is used for most watersheds where records are short. Calibration of the sediment transport model is a more difficult problem, since few, if any, records exist describing this phenomenon. However, it is believed that engineering judgment applied to this problem can produce reasonable results.

\section{Other Canyons along the Front Range}

Although the Big Thompson flash flood was only one of many catastrophic floods that have hit the Front Range, recorded history notes only one other flood of similar proportions. On June 9, 1972, identical 
meteorologic conditions dropped almost 15 inches of rainfall during a 6 hour period over a small portion of the Rapid Creek Basin above Rapid City, South Dakota (U.S. Corps of Engineers, 1973). The flood crest in the canyon was ahout $31,200 \mathrm{cfs}$. Downstream the floodwaters overtopped Canyon Lake Dam, resulting in the Rapid City flood crest at 50,000 cfs (USGS, 1975). At last count, 237 people died and economic losses exceeded $\$ 164,000,000$. In general, geologists believe that floods of this magnitude have occurred prior to historic records. Evidence of these floods can be seen in the poor soil development of debris fans (Soule et a1., 1977). Smaller flash floods have also been recorded along the Front Range. These are summarized in Table 5.

TABLE 5

Major Floods along the Colorado Front Range (Follansbee, 1948)

\begin{tabular}{|c|c|c|c|}
\hline STREAM & DATE & DISCHARGE & CAUSE \\
\hline Clear Creek & $\begin{array}{l}8-1-88 \\
9-2-38\end{array}$ & $\begin{array}{l}8,700 \mathrm{cfs} \\
4,090\end{array}$ & $\begin{array}{l}\text { Cloudburst } \\
\text { Cloudburst }\end{array}$ \\
\hline St. Vrain Creek & $\begin{array}{l}5-31-94 \\
7-31-19\end{array}$ & $\begin{array}{l}9,800 \\
9,400\end{array}$ & Cloudburst \\
\hline Boulder Creek & $5-30-94$ & $12,000($ est $)$ & $\begin{array}{l}\text { Cloudburst over } \\
\text { snowmelt }\end{array}$ \\
\hline South Boulder Creek & $9-2-38$ & 7,390 & Cloudburst \\
\hline Big Thompson River & \multicolumn{2}{|c|}{ See Table 1} & \\
\hline Buckhorn Creek & $\begin{array}{l}6-15-23 \\
9-1-38 \\
8-3-51\end{array}$ & $\begin{array}{l}10,500 \\
10,200 \\
14,000\end{array}$ & $\begin{array}{l}\text { Cloudburst } \\
\text { Cloudburst } \\
\text { Dambreak }\end{array}$ \\
\hline Redstone Creek & $\begin{array}{l}6-15-23 \\
9-\quad 1-38\end{array}$ & $\begin{array}{l}6,820 \\
8,400\end{array}$ & $\begin{array}{l}\text { Cloudburst } \\
\text { Cloudburst }\end{array}$ \\
\hline Cache La Poudre River & $\begin{array}{l}6-9-91 \\
5-21-01 \\
5-20-04 \\
5-31-30\end{array}$ & $\begin{array}{l}21,000 \\
12,000 \\
21,000(\text { est }) \\
10,200\end{array}$ & $\begin{array}{l}\text { Dambreak } \\
\text { Cloudburst } \\
\text { Cloudburst }\end{array}$ \\
\hline $\begin{array}{l}\text { North Fork Cache La Poudre } \\
\text { River }\end{array}$ & $\begin{array}{l}5-20-04 \\
5-31-30\end{array}$ & $\begin{array}{r}20,000 \\
6,800\end{array}$ & $\begin{array}{l}\text { Cloudburst } \\
\text { Cloudburst }\end{array}$ \\
\hline
\end{tabular}

It should be noted that several of the floods listed in the Table were identified with dam failures. Many small dams are inadequately designed with steep side slopes along earthfill embankments and inadequate spillways. Flash floods resulting from heavy rainfall can overtop these structures and cause dam failure and serious flooding downstream.

The occurrence of these floods is a reminder of the flood hazards associated with mountain canyons all along the Front Range. Many of these canyons have equal or greater developments than the Big Thompson 
along their floodways and, therefore, have a capability for greater tragedy. For example, Boulder Canyon empties into the city of Boulder, Colorado. A flash flood along this stream would rip into the city, taking a staggering toll of 1 ife and property. So far, flood planning efforts have been directed toward the Big Thompson Canyon. Other canyons have been ignored (although some flood planning has taken place in Boulder and other urban areas along the foothills). But development still continues in these areas. Will it take another tragedy to make residents realize the risks?

\section{SUMMARY}

Meteorological conditions preceding the Big Thompson flood showed unusual developments on the macroscale. A high-pressure system dominated the region, causing slow movement of developing thunderstorm cells. These cells developed in a relatively deep moist layer which reached its maximum vertical dimensions north of Denver. Thunderstorm development was aided by high upslope winds in the moist layer close to the ground. Once the thunderstorm in the Big Thompson area developed, it was sustained and enforced by the continuous supply of moist air pressing against the mountain slopes. The weak or almost calm wind field in the upper atmosphere caused the thunderstorm to become almost stationary, releasing the observed inordinately large amounts of precipitation.

The torrential rainfall that centered over a small area caused spectacular flash flooding. Velocities along the main stem commonly exceeded 20 fps. The peak discharge at the mouth of the canyon was $31,200 \mathrm{cfs}$. When the flow entered the plains, it was quickly attenuated by overbank storage. Table 2 summarizes flood discharge data. The return period varied from several thousand years in the rainfall area to about 300 years at the mouth of the canyon. Discharge frequency data are presented in Table 3.

Vast amounts of sediment were moved along with the streamflow during the flood. In the rainfall area, sheet erosion and severe scour along gullies and small tributaries introduced large amounts of materials into the main stem. This influx overloaded the main stem with sediment, causing the deposition of large amounts of materials. Downstream along the main stem, scour occurred where the valley was narrow and/or where the stream gradient was very steep. Areas of deposition occurred where the valley widened and/or where the stream gradient was very shallow. Stream competence along these stretches varied from boulder sizes in scour areas to silts and sands in areas of deposition. Downstream of the canyon's mouth on the plains, large amounts of materials (over $2 \mathrm{ft}$ in some places) were deposited as the valley enlarged and the stream gradient decreased. Figures 17 through 21 summarize sediment transport during the flood.

The geotechnical engineering aspects of the flood were considered. These aspects included several different catagories. Roadways and bridge 
structures were damaged by erosion of embankments and supporting fills. Building foundations failed either by the forces of water acting directly on them or by erosion of foundation bearing material. Landslides and rock falls were numerous. These resulted from toe erosion, the development of pore water pressure, and seepage forces caused by the heavy rainfall. Slope failures occurred not only immediately after or during the flood, but movements are also continuing a year after the flood.

The report reviews the damage caused by the flood and remedial measures during the following year. The need for not only adequate floodplain management but also geological hazard analysis outside of the floodplain is stressed. Conclusions regarding the nature of damages with regard to geotechnical engineering are presented.

Damages directly related to the flood exceeded $\$ 41,000,000$. These losses are summarized in Table 4. Indirect losses to business interests may have exceeded $\$ 5,000,000$.

The flash flood caused a change in the acceptable level of risk in the Big Thompson canyon. As a result, local governments introduced floodplain zoning to reduce the impact of future events. Local residents resented the restrictions on the use of their property, especially since they felt a similar event would not occur again for several hundred years.

Because of the hardship endured by local residents from flood zoning, flood insurance studies must accurately represent hazard areas. Conventional techniques for floodplain analysis are not always applic$a b l e$ to mountain watersheds because they do not simulate the flood processes. Instead, a new model which simulates these processes needs to be developed.

The occurrence of the Big Thompson flash flood and the Rapid City flash flood of 4 years earlier provides a grim reminder of the flood hazards that exist for canyons all along the Front Range. Adequate flood planning should be introduced to limit the scope of future disasters. 


\section{BIBLIOGRA PHY}

Braddock, William A., et a1., "Geologic Map of the Drake Quadrangle, Larimer County, Colorado," U.S. Geological Survey Map GQ 829, 1970

Braddock, William A., et al., "Geologic Map of the Masonville Quadrangle, Larimer County, Colorado," U.S. Geological Survey Map GQ 832, 1970

Dirks, R. A., "A Theoretical Investigation of the Convective Patterns in the Lee of the Rockies," Atmospheric Science Paper No. 145, Department of Earth Sciences, Colorado State University, Fort Collins, Colorado, 1976

Doehring, Donald O., Ed., The Big Thompson Flood of 1976 (a field trip guide book for the 1976 meeting of the Geological Society of America), Department of Earth Sciences, Colorado State University, Fort Collins, Colorado, 1976

Follansbee, Robert, and Leon A. Sawyer, "Floods in Colorado," U.S. Geological Survey Water Supply Paper 997, 1948

Gingery and Associates, Inc., "Special Flood Plain Information Report, Big Thompson River and Tributaries, Larimer County, Colorado," Englewood, Colorado, 1976

Larimer County Planning Commission, "Flood Plain Amendment to the Larimer County Building Code," 1977

Kleher, John T., and Malcolm D. Gifford, "Stream Flow Analysis of the Big Thompson Flood," Department of Atmospheric Sciences, Colorado State University, Fort Collins, Colorado, 1976

McCain, Jerald R., Colorado District U.S. Geological Survey, Personal Communication, April 1977

Maddox, Robert A., et a1., "Meteorological Aspects of the Big Thompson Flash Flood of 31 July 1976," National Oceanic and Atmospheric Administration Technical Report, TR ERL 388-APCL41, 1977

Soule, James M., et al., "Geologic Hazards, Geomorphic Features, and Fan Use Implications in the Area of the Big Thompson Flash Flood, Larimer County, Colorado," Colorado Geologic Survey Publication EG-10, Denver, Colorado, 1977

Toups Corporation, Big Thompson Disaster Planning Recovery Report, Vol. 1, Loveland, Colorado, 1977

U.S. Army Corps of Engineers, Omaha District, "Flood Plain Information Report, Rapid City, South Dakota," June 1973

U.S. Army Corps of Engineers, Omaha District, "Post Flood Report, Big Thompson River Flood of 31 July-1 August, 1976," December 1976

U.S. Geological Survey, "The Black Hills - Rapid City Flood of June 9-10, 1972," Professional Paper 877, 1975 
U.S. Geological Survey and Colorado Water Conservation Board, "The Big Thompson River Flood of July 31 - August 1, 1976, Larimer County, Colorado, Flood Information Report," October 1976

Wiesman, C. J., Hydrometeorology, Chapman and Ha11, Ltd., London, England, 1970

White, Gilbert F., and J. Eugene Haas, Assessment of Research in Natural Hazards, MIT Press, Cambridge, Massachusetts, 1975 